RECEVED

ORNL-6835

AlJg 201996

NSTI

\section{The Potential for Low Petroleum Gasoline}

\author{
G. R. Hadder \\ G. M. Webb \\ M. Clauson
}

\section{RECRVED \\ JUL 17 1998 \\ OSTI}

DASTRBUTION OF THES DOCUAENT IS UALMITED
MANAGED AND OPERATED BY LOCKHEED MARTN ENERGY RESEARCH CORPORATION FOR THE UNTED STATES DEPARTMENT OF ENERGY 
This report has been reproduced directly from the best available copy.

Avallable to DOE and DOE contractors from the Office of Scientific and Technical Information, P.O. Box 62, Oak Ridge, TN 37831; prices available from (423) 576-8401, FTS 626-8401.

Available to the public from the National Technical Information Service, U.S. Department of Commerce, 5285 Port Royal Rd., Springfield, VA 22161.

This report wes prepared as an account of work sponsored by an agency of the United States Government. Neither the United States Govemment nor any agency thereof, nor any of their employees, makes any warranty, express or implied, or assumes any legal liability or responsibility for the Bccuracy, completeness, or usefulness of any information, apparatus, product, or process disclosed, or represents that its use would not infringe privately owned rights. Reference herein to any specific commercial product, process, or service by trade name, trademark, manufacturer, or otherwise, does not necessarily constitute or imply its endorsement, recommendation, or favoring by the United States Government or any agency thereof. The views and opinions of authors expressed herein do not necessarily state or reflect those of the United States Government or any agency thereof. 
Energy Division

\title{
THE POTENTIAL FOR LOW PETROLEUM GASOLINE
}

\author{
Principal Investigators \\ G. R. Hadder \\ G. M. Webb \\ M. Clauson
}

June 1996

\author{
Report Prepared for \\ Office of Policy \\ U.S. Department of Energy
}

\author{
Prepared by the \\ Energy and Environmental Analysis, Inc. \\ Arlington, Virginia 22209 \\ and \\ OAK RIDGE NATIONAL LABORATORY \\ Oak Ridge, Tennessee 37831-6366 \\ managed by \\ LOCKHEED MARTIN ENERGY RESEARCH CORP. \\ for the \\ U.S. DEPARTMENT OF ENERGY \\ under contract DE-AC05-96OR22464
}




\section{DISCLAIMER}

Portions of this document may be illegible in electronic image products. Images are produced from the best available original document. 


\section{TABLE OF CONTENTS}

LIST OF TABLES $\ldots \ldots \ldots \ldots \ldots \ldots \ldots \ldots \ldots \ldots \ldots \ldots \ldots \ldots \ldots \ldots \ldots$

LIST OF FIGURES $\ldots \ldots \ldots \ldots \ldots \ldots \ldots \ldots \ldots \ldots \ldots \ldots \ldots \ldots \ldots$

ACRONYMS AND ABBREVIATIONS $\ldots \ldots \ldots \ldots \ldots \ldots \ldots \ldots \ldots \ldots \ldots \ldots \ldots$

ACKNOWLEDGEMENTS $\ldots \ldots \ldots \ldots \ldots \ldots \ldots \ldots \ldots \ldots \ldots \ldots \ldots \ldots \ldots$

ABSTRACT $\ldots \ldots \ldots \ldots \ldots \ldots \ldots \ldots \ldots \ldots \ldots \ldots \ldots \ldots \ldots \ldots \ldots \ldots \ldots$

EXECUTIVE SUMMARY $\ldots \ldots \ldots \ldots \ldots \ldots \ldots \ldots \ldots \ldots \ldots \ldots \ldots$

1. LEGISLATIVE BASIS FOR LOW PETROLEUM GASOLINE $\ldots \ldots \ldots \ldots \ldots$

2. THE CLEAN AIR ACT AMENDMENTS OF $1990 \ldots \ldots \ldots \ldots \ldots \ldots \ldots \ldots$

3. THE ORNL REFINERY YIELD MODEL $\ldots \ldots \ldots \ldots \ldots \ldots \ldots \ldots \ldots$

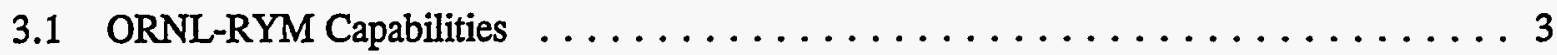

3.2 Representation of Non-linear Emissions Models in a Linear Program . . . . . . . . . 5

4. PREMISES FOR LOW PETROLEUM STUDY $\ldots \ldots \ldots \ldots \ldots \ldots \ldots \ldots \ldots$

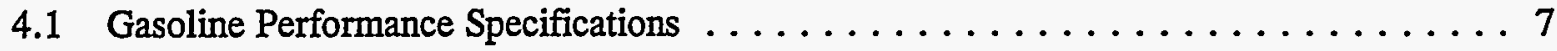

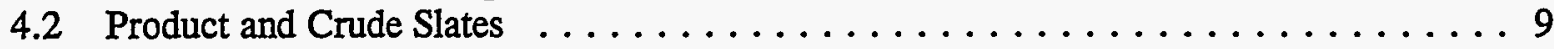

4.3 Limits on Transportation Fuel Properties $\ldots \ldots \ldots \ldots \ldots \ldots \ldots \ldots$

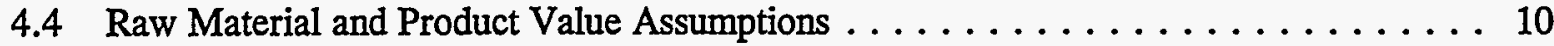

4.5 Treatment of Capital Cost Recovery $\ldots \ldots \ldots \ldots \ldots \ldots \ldots \ldots \ldots \ldots \ldots$

4.6 Base Cases (Cost Reference Cases) $\ldots \ldots \ldots \ldots \ldots \ldots \ldots \ldots \ldots \ldots$

5. LOW PETROLEUM GASOLINE COMPONENTS ............... 12

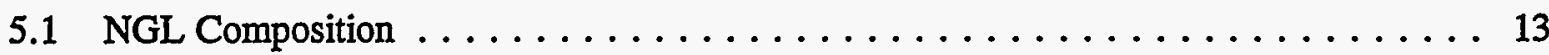

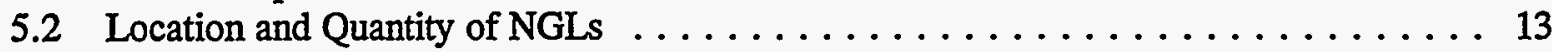

5.3 NGL Quality . . . . . . . . . . . . . . . . . . . . . . 14

5.4 NGL Extraction/Production Methods and Associated Costs . . . . . . . . . . . 14

5.4 .1 Straight Refrigeration . . . . . . . . . . . . . . . . 14

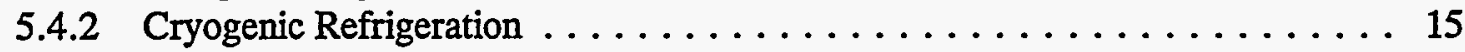

5.5 NGL Transportation Modes and Associated Costs $\ldots \ldots \ldots \ldots \ldots \ldots \ldots$

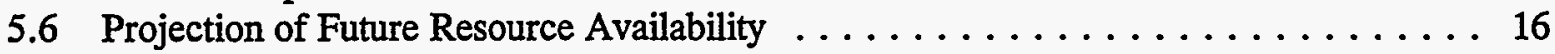

6. PRODUCTION OF LOW PETROLEUM SUMMER GASOLINE . . . . . . . . . . . . . 17

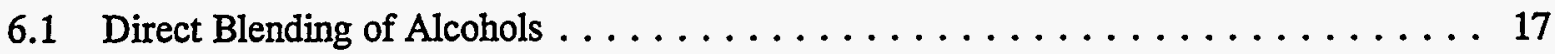

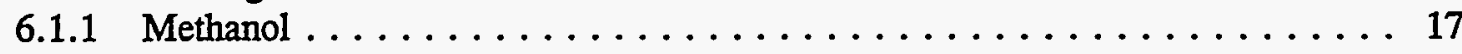

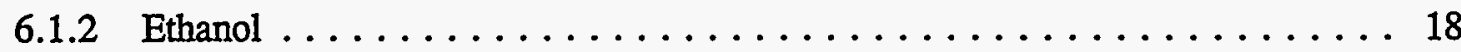


TABLE OF CONTENTS (continued)

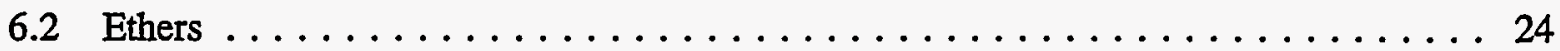

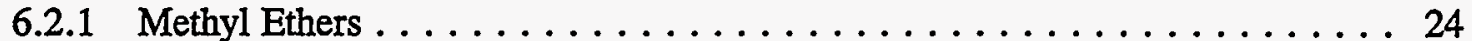

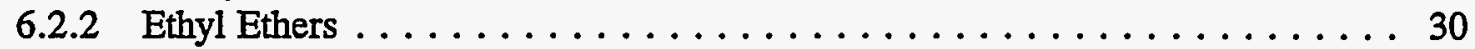

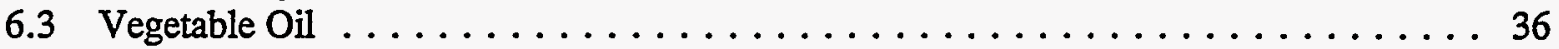

7. COMPARISON OF LOW PETROLEUM SUMMER GASOLINE OPTIONS $\ldots \ldots \ldots \ldots 42$

8. PRODUCTION OF LOW PETROLEUM WINTER GASOLINE $\ldots \ldots \ldots \ldots \ldots \ldots 45$

9. GREENHOUSE GAS EMISSIONS OF LOW PETROLEUM GASOLINES $\ldots \ldots \ldots \ldots 49$

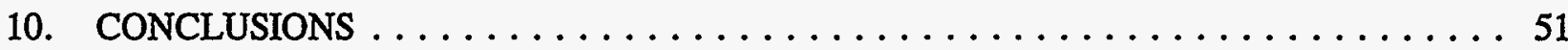

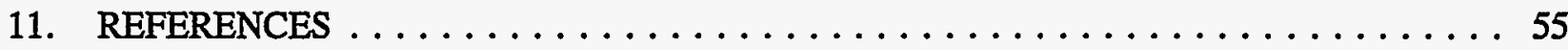

APPENDIX A. RAW MATERIAL SUPPLY CURVE ESTIMATION $\ldots \ldots \ldots \ldots \ldots$ A-1

APPENDIX B. BLENDSTOCKS, PROPERTIES, PROCESS INVESTMENTS,

AND FUEL USE FOR SUMMER GASOLINE PRODUCTION . . . . . . . B-1

APPENDIX C. HYDROGEN REPLACEMENT FUEL CREDITS $\ldots \ldots \ldots \ldots \ldots \ldots$ C-1

APPENDIX D. BLENDSTOCKS, PROPERTIES, PROCESS INVESTMENTS,

AND FUEL USE FOR WINTER GASOLINE PRODUCTION . . . . . . D D-1

APPENDIX E. LOW PETROLEUM COST CHANGE FOR CG RVP INCREASE

TO 8.7 PSI $\ldots \ldots \ldots \ldots \ldots \ldots \ldots \ldots \ldots \ldots \ldots \ldots \ldots \ldots \ldots \ldots \ldots \ldots$ 


\section{LIST OF TABLES}

Table 1. Formula and emissions performance standards for the federal RFG program . . . . . 2

Table 2. Key refinery process characterization for year $2010 \ldots \ldots \ldots \ldots \ldots$

Table 3. Complex model representation in ORNL-RYM by linear delta method . . . . . . . 6

Table 4. Emissions performance targets for reformulated gasoline produced in PADD III

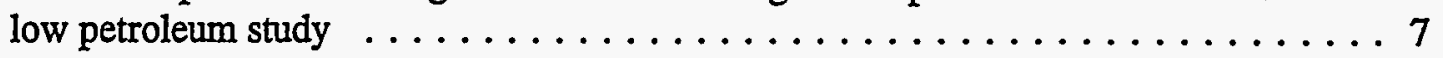

Table 5. Historical PADD III summer gasoline properties $\ldots \ldots \ldots \ldots \ldots \ldots$

Table 6. Quality of crude oil processed by PADD III refineries $\ldots \ldots \ldots \ldots \ldots$

Table 7. Product price differentials $\ldots \ldots \ldots \ldots \ldots \ldots \ldots \ldots \ldots \ldots \ldots$

Table 8. Octane and RVP for RFG and blendstocks $\ldots \ldots \ldots \ldots \ldots$

Table 9. PADD III low petroleum components for the year 2010 summer: Ethanol blends . . 21

Table 10. PADD III low petroleum costs for the year 2010 summer: Ethanol blends . . . . . 22

Table 11. PADD III low petroleum effects on distillate blendstock: Ethanol blended

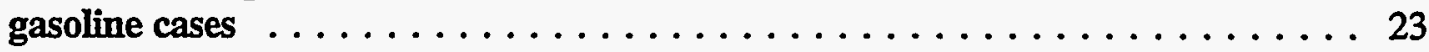

Table 12. PADD III low petroleum components for the year 2010 summer: Methyl

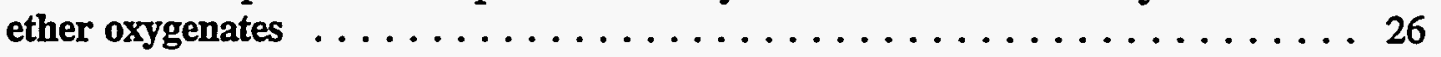

Table 13. PADD III low petroleum price elasticity variations for the year 2010 summer: Methyl ether oxygenates . . . . . . . . . . . . . . . 28

Table 14. PADD III low petroleum effects on distillate blendstocks: Methyl ether oxygenated gasoline cases . . . . . . . . . . . . . . . . . 29

Table 15. PADD III low petroleum components for the year 2010 summer:

Ethyl ether oxygenates . . . . . . . . . . . . . . . . 32

Table 16. PADD III low petroleum price elasticity variations for the year 2010 summer: Ethyl ether oxygenates . . . . . . . . . . . . . 34

Table 17. PADD III low petroleum effects on distillate blendstocks: Ethyl ether

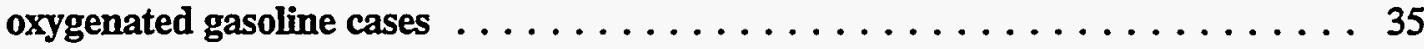

Table 18. Range of blending properties of rapeseed-associated FCC naphthas . . . . . . 37 


\section{LIST OF TABLES (continued)}

Table 19. PADD III low petroleum components for the year 2010 summer:

Rapeseed oil feedstock . . . . . . . . . . . . . . . . . . 39

Table 20. PADD III low petroleum price elasticity variations for the year 2010

summer: Rapeseed oil feedstock . . . . . . . . . . . . . . . . 40

Table 21. PADD III low petroleum effects on distillate blendstocks: Rapeseed

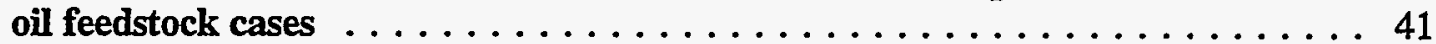

Table 22. PADD III input/output comparisons $\ldots \ldots \ldots \ldots \ldots \ldots \ldots$

Table 23. PADD III low petroleum components for the year 2010 winter . . . . . . . . . 47

Table 24. PADD III low petroleum price elasticity variations for the year 2010 winter . . . . . 48

Table 25. Greenhouse gas emissions of gasoline components $\ldots \ldots \ldots \ldots \ldots \ldots$

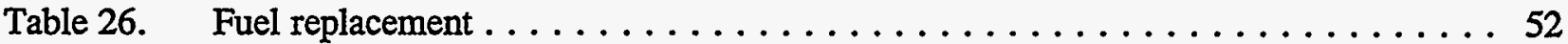

Table B-1. PADD III base case blendstocks for year 2010 summer . . . . . . . . . . . . . . . B-1

Table B-2. PADD III base case gasoline properties for the year 2010 summer . . . . . . . . B-2

Table B-3. RFG blendstocks in PADD III for the year 2010 summer: Ethanol blends . . . . . B-3

Table B-4. CG blendstocks in PADD III for the year 2010 summer: Ethanol blends . . . . . B-4

Table B-5. PADD III RFG properties for the year 2010 summer: Ethanol blends . . . . . . . B-5

Table B-6. PADD III CG properties for the year 2010 summer: Ethanol blends . . . . . . . . B-6

Table B-7. PADD III process capacity investments for the year 2010 summer: Ethanol blends

Table B-8. PADD III low petroleum refinery fuel use for the year 2010 summer:

Ethanol blends

Table B-9. RFG blendstocks in PADD III for the year 2010 summer: Methyl ether oxygenates

Table B-10. CG blendstocks in PADD III for the year 2010 summer: Methyl ether oxygenates 


\section{LIST OF TABLES (continued)}

Table B-11. PADD III RFG properties for the year 2010 summer: Methyl ether

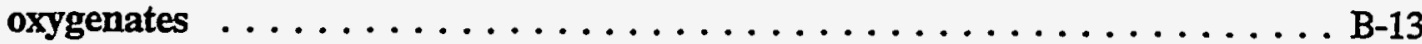

Table B-12. PADD III CG properties for the year 2010 summer: Methyl ether oxygenates . . . B-15

Table B-13. PADD III process capacity investments for the year 2010 summer: Methyl ether oxygenates . . . . . . . . . . . . . . . B-17

Table B-14. PADD III low petroleum refinery fuel use for the year 2010 summer: Methyl ether oxygenates . . . . . . . . . . . . . . . . . . . B-19

Table B-15. RFG blendstocks in PADD III for the year 2010 summer: Ethyl ether oxygenates $\ldots \ldots \ldots \ldots \ldots \ldots \ldots \ldots \ldots \ldots \ldots$. . . . . . . . . . .

Table B-16. CG blendstocks in PADD III for the year 2010 summer: Ethyl ether

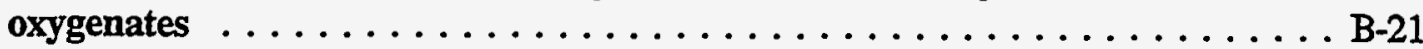

Table B-17. PADD III RFG properties for the year 2010 summer: Ethyl ether

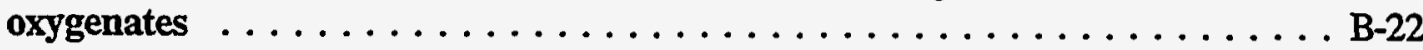

Table B-18. PADD III CG properties for the year 2010 summer: Ethyl ether oxygenates . . . B-23

Table B-19. PADD III process capacity investments for the year 2010 summer:

Ethyl ether oxygenates . . . . . . . . . . . . . . . . . . B-24

Table B-20. PADD III low petroleum refinery fuel use for the year 2010 summer:

Ethyl ether oxygenates $\ldots \ldots \ldots \ldots \ldots \ldots \ldots \ldots \ldots$. . . . . . . . . . . . .

Table B-21. RFG blendstocks in PADD III for the year 2010 summer: Rapeseed oil feedstock $\ldots \ldots \ldots \ldots \ldots \ldots \ldots \ldots \ldots \ldots \ldots$ B $26 \ldots \ldots \ldots \ldots$

Table B-22. CG blendstocks in PADD III for the year 2010 summer: Rapeseed oil feedstock

Table B-23. PADD III RFG properties for the year 2010 summer: Rapeseed oil feedstock . . . B-28

Table B-24. PADD III CG properties for the year 2010 summer: Rapeseed oil feedstock . . . . B-29

Table B-25. PADD III process capacity investments for the year 2010 summer:

Rapeseed oil feedstock B-30

Table B-26. PADD III low petroleum refinery fuel use for the year 2010 summer:

Rapeseed oil feedstock B-31 


\section{LIST OF TABLES (continued)}

Table D-1. PADD III base case blendstocks for year 2010 winter . . . . . . . . . . . . . D D-1

Table D-2. PADD III base case gasoline properties for the year 2010 winter $\ldots \ldots \ldots$. . . D-2

Table D-3. RFG blendstocks in PADD III for the year $2010 \ldots \ldots \ldots \ldots \ldots \ldots$

Table D-4. CG blendstocks in PADD III for the year 2010 winter $\ldots \ldots \ldots \ldots \ldots$. . . . . D-4

Table D-5. PADD III RFG properties for the year 2010 winter $\ldots \ldots \ldots \ldots \ldots \ldots \ldots$

Table D-6. PADD III CG properties for the year 2010 winter . . . . . . . . . . . . . D-6

Table D-7. PADD III process capacity investments for the year 2010 winter . . . . . . . . . D-7

Table D-8. PADD III low petroleum refinery fuel use for the year 2010 winter . . . . . . . . D-8

Table E-1. PADD III low petroleum cost change for CG RVP increase to 8.7 psi:

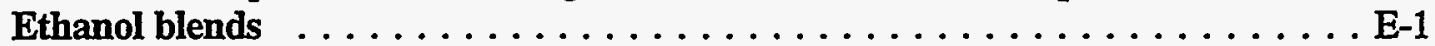

Table E-2. PADD III low petroleum cost change for CG RVP increase to 8.7 psi: Methyl ether oxygenates . . . . . . . . . . . . . . E-2

Table E-3. PADD III low petroleum cost change for CG RVP increase to 8.7 psi: Ethyl ether oxygenates $\ldots \ldots \ldots \ldots \ldots \ldots \ldots \ldots \ldots \ldots \ldots \ldots$

Table E-4 PADD III low petroleum cost change for CG RVP increase to 8.7 psi:

Rapeseed oil feedstock . . . . . . . . . . . . . . . . . . E-4 


\section{LIST OF FIGURES}

Figure 1. Crude oil supply curve for PADD III . . . . . . . . . . . . . . 59

Figure 2. Natural gas supply curve for $\mathrm{PADD}$ III $\ldots \ldots \ldots \ldots \ldots$

Figure 3 . Corn-derived ethanol supply curve $\ldots \ldots \ldots \ldots \ldots \ldots \ldots \ldots \ldots \ldots \ldots \ldots \ldots \ldots$

Figure 4. Low Petroleum Gasoline: Possible Petroleum Displacement Sources . . . . . . . . 62

Figure $5 . \quad$ RFG and blendstock VOC emissions values $\ldots \ldots \ldots \ldots \ldots \ldots$

Figure 6. NOx and VOC sensitivity to oxygen from methyl ethers $\ldots \ldots \ldots \ldots \ldots$

Figure 7. Toxics emissions sensitivity to oxygen from methyl ethers $\ldots \ldots \ldots \ldots$

Figure 8. Toxics emissions sensitivity to oxygen from ethyl ethers $\ldots \ldots \ldots \ldots$

Figure 9. Refining cost increases for low petroleum gasoline $\ldots \ldots \ldots \ldots \ldots$

Figure 10. Refining cost increase for low petroleum gasoline cases . . . . . . . . . 68

Figure 11. Non-petroleum share for low petroleum gasoline cases $\ldots \ldots \ldots \ldots \ldots \ldots$

Figure 12. Cost to reduce crude oil use in low petroleum gasoline policy . . . . . . . . . 73

Figure 13. Cost to reduce crude oil use in low petroleum gasoline cases $\ldots \ldots \ldots$. . . . . 74

Figure 14. Crude oil use reduction in low petroleum gasoline policy $\ldots \ldots \ldots \ldots \ldots$

Figure 15. Crude oil use reduction in low petroleum gasoline cases $\ldots \ldots \ldots \ldots$

Figure 16 . Low petroleum refinery fuel use $\ldots \ldots \ldots \ldots \ldots \ldots \ldots \ldots \ldots$

Figure 17. Refinery fuel use in low petroleum gasoline cases $\ldots \ldots \ldots \ldots \ldots$

Figure 18. Refinery investment for low petroleum gasoline policy . . . . . . . . . . . 79

Figure 19. Refinery investment in low petroleum gasoline cases . . . . . . . . . . 80

Figure 20. Greenhouse gas emissions for low petroleum gasoline . . . . . . . . . . 81

Figure 21. Greenhouse gas emissions for low petroleum gasolines relative to base gasolines ... 82

Figure 22. Cost increases for low petroleum gasoline, CG RVP $\max =8.7 \mathrm{psi} \ldots \ldots . \ldots 3$

Figure 23. Price elasticity effect on cost to reduce crude oil use in low petroleum gasoline . . . . 84

Figure 24. Year-round refining cost increase for near-30 percent non-petroleum in gasoline $\ldots .85$

Figure 25. Year-round refining cost to reduce crude oil use for near-30 percent non-petroleum in gasoline $\ldots \ldots \ldots \ldots \ldots \ldots \ldots \ldots$

Figure 26. Year-round relative greenhouse gases for near-30 percent non-petroleum

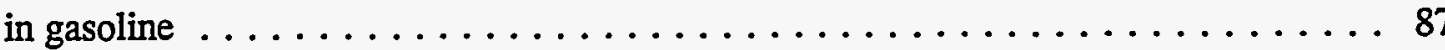




\section{ACRONYMS AND ABBREVIATIONS}

API

ASTM

BTU

C

CAAA

CG

$\mathrm{CO}_{2}$

DOE

EEA

EIA

EPA

EPACT

ETBE

EtOH

E200

E300

F

FCC

GE

GHG

GTBA
American Petroleum Institute

American Society for Testing and Materials

British Thermal Unit

Centigrade

Clean Air Act Amendments of 1990

Conventional gasoline

Carbon dioxide

Department of Energy

Energy and Environmental Analysis, Inc.

Energy Information Administration

Environmental Protection Agency

Energy Policy Act

Ethyl tertiary butyl ether

Ethanol

The cumulative volume percent evaporated at $200^{\circ} \mathrm{F}$

in ASTM test D86-67: Distillation of Petroleum Products

The cumulative volume percent evaporated at $300^{\circ} \mathrm{F}$ in ASTM test D86-67: Distillation of Petroleum Products

Fahrenheit

Fluid catalytic cracker

Gasoline energy equivalent

Greenhouse gas

Gasoline grade tertiary butyl alcohol 


\section{ACRONYMS AND ABBREVIATIONS (continued)}

\begin{tabular}{|c|c|}
\hline $\mathrm{LCO}$ & Light cycle oil \\
\hline $\mathbf{M}$ & Motor octane number \\
\hline $\mathrm{MBD}$ & Thousand barrels per day \\
\hline $\mathrm{MCF}$ & Thousand cubic feet \\
\hline $\mathrm{mg} / \mathrm{mi}$ & Milligrams per mile \\
\hline MMSCFD & Million standard cubic feet per day \\
\hline MTBE & Methyl tertiary butyl ether \\
\hline NA & Not applicable \\
\hline NGL & Natural gas liquid \\
\hline NOx & Nitrogen oxide \\
\hline ORNL-RYM & Oak Ridge National Laboratory Refinery Yield Model \\
\hline PADD & Petroleum Administration for Defense District \\
\hline ppm & Parts per million \\
\hline psi & Pounds per square inch, absolute \\
\hline $\mathbf{R}$ & Research octane number \\
\hline RFG & Reformulated gasoline \\
\hline ROI & Return on investment \\
\hline RVP & Reid vapor pressure \\
\hline TAEE & Tertiary amyl ethyl ether \\
\hline TAME & Tertiary amyl methyl ether \\
\hline TAP & Toxic air pollutant \\
\hline THEE & Tertiary hexyl ethyl ether \\
\hline
\end{tabular}




\section{ACRONYMS AND ABBREVIATIONS (continued)}

THME

T50

T90

VOC

vol

wt
Tertiary hexyl methyl ether

The temperature at which 50 percent of a fuel is evaporated in ASTM test D86-67: Distillation of Petroleum Products

The temperature at which 90 percent of a fuel is evaporated in ASTM test D86-67: Distillation of Petroleum Products

Volatile organic compound

Volume

Weight 


\section{ACKNOWLEDGEMENTS}

Support and technical guidance for study of the potential for low petroleum gasoline have been provided by Barry McNutt and Ben Massell of the Office of Policy of the Department of Energy (DOE). Insights on refinery trends and petroleum markets have been provided by the Product Quality Task Group of the National Petroleum Council Committee on Refining and by Margaret Singh of the Argonne National Laboratory. Technical guidance, data resources, and access to forecasting models have been furnished by the DOE Energy Information Administration. EnSys Energy \& Systems, Inc. has assisted in modification of the refinery models. During the early phases of development and application of the Oak Ridge National Laboratory Refinery Yield Model used in these studies, support and guidance were also received from the Navy Energy \& Natural Resources Office. The valuable contributions of these organizations and individuals are greatly appreciated. 


\begin{abstract}
The Energy Policy Act requires the Secretary of Energy to determine the feasibility of producing sufficient replacement fuels to replace at least 30 percent of the projected consumption of motor fuels by light duty vehicles in the year 2010. The Act also requires the Secretary to determine the greenhouse gas implications of the use of replacement fuels. A replacement fuel is a non-petroleum portion of gasoline, including certain alcohols, ethers, and other components. The Oak Ridge National Laboratory Refinery Yield Model has been used to study the cost and refinery impacts for production of "low petroleum" gasolines, which contain replacement fuels. The analysis suggests that high oxygenation is the key to meeting the replacement fuel target, and a major contributor to cost increase is investment in processes to produce and etherify light olefins. High oxygenation can also increase the costs of control of vapor pressure, distillation properties, and pollutant emissions of gasolines. Year-round low petroleum gasoline with near-30 percent non-petroleum components might be produced with cost increases of 23 to 37 cents per gallon of gasoline, and with greenhouse gas emissions changes between a 3 percent increase and a 16 percent decrease. Crude oil reduction, with decreased dependence on foreign sources, is a major objective of the low petroleum gasoline program. For year-round gasoline with near-30 percent non-petroleum components, crude oil use is reduced by 10 to 12 percent, at a cost $\$ 48$ to $\$ 89$ per barrel. Depending upon resolution of uncertainties about extrapolation of the Environmental Protection Agency Complex Model for pollutant emissions, availability of raw materials and other issues, costs could be lower or higher.
\end{abstract}




\section{THE POTENTIAL FOR LOW PETROLEUM GASOLINE}

\section{EXECUTIVE SUMMARY}

The Energy Policy Act (EPACT) requires the Secretary of Energy to determine the feasibility of producing sufficient replacement fuels to replace at least 30 percent of the projected consumption of motor fuels by light duty vehicles in the year 2010. EPACT also requires the Secretary to determine the greenhouse gas emission implications of increasing the use of replacement fuels. EPACT defines replacement fuel as "the portion of any motor fuel that is methanol, ethanol, or other alcohols, natural gas, liquified petroleum gas, hydrogen, coal derived liquid fuels, fuels (other than alcohol) derived from biological materials, electricity (including electricity from solar energy), ethers, or any other fuel the Secretary determines, by rule, is substantially not petroleum and would yield substantial energy security benefits and substantial environmental benefits."

Gasoline is the predominant fuel for light duty vehicles. The Oak Ridge National Laboratory Refinery Yield Model (ORNL-RYM) has been used to study the potential for production of gasoline with high percentages of replacement fuels in the year 2010. Like all highway gasolines, these "low petroleum" gasolines must comply with requirements of the Clean Air Act Amendments of 1990 (CAAA). ORNL-RYM represents the production of gasolines which satisfy CAAA emissions constraints described in terms of the Environmental Protection Agency's final Complex Model.

The low petroleum gasoline study investigates replacement of petroleum by:

- Direct blending or conversion of alcohols:

Methanol (derived from natural gas) and ethanol can be directly blended into gasoline for replacement fuel credit. Gasoline grade tertiary butyl alcohol is directly blended as a cosolvent with methanol. Methanol and ethanol can also be converted into ethers.

- Direct blending of ethers:

Replacement fuel credit is given for purchased methyl tertiary butyl ether and ethyl tertiary butyl ether, which are assumed to be derived from non-petroleum sources.

For ethers produced in the refinery, the associated alcohol is credited as a replacement fuel.

- Hydrogenation:

Hydrogen derived from non-petroleum sources and used in hydrogenation processes can be credited as a replacement fuel in gasoline. However, there should be deductions for hydrogen used in desulfurization, fuel gas, and.in hydrogenation of blendstocks for products other than low petroleum gasoline.

- Conversion of vegetable oil:

It is assumed that rapeseed oil can be used as a feedstock for future cracking technologies. The rapeseed oil component of gasoline blendstocks is credited as replacement fuel. 
Replacement fuel credit is also given for purchased components of natural gas liquids (NGLs include ethane, propane, butanes and natural gasoline). These non-petroleum components may be used in the production of ethers, alkylate, reformate and other gasoline blendstocks. If large volumes of ethers are used in low petroleum gasoline, production costs could be particularly sensitive to the availability of NGL component raw materials for ether production.

The analysis of year 2010 summer production of low petroleum gasoline suggests that the 30 percent replacement fuel target can be achieved at a high cost. Incremental costs to meet the 30 percent replacement fuel target could be more than three times the incremental costs to produce Phase II reformulated gasoline in the U.S. Gulf Coast refining system. High oxygenation is the key to meeting the replacement fuel target, and a major contributor to cost increase is investment in processes to produce and etherify light olefins. High oxygenation can also increase the costs of control of vapor pressure, distillation properties, and pollutant emissions of gasolines. Crude oil reduction, with decreased dependence on foreign sources, is a major objective of the low petroleum gasoline program. In the analysis, crude oil use is reduced by 10 to 17 percent.

There are uncertainties in the premises for study of low petroleum gasoline production, and costs can be considerably different for alternative premises. There could be large cost impacts with different assumptions about:

Availability of cellulosic ethanol.

Extrapolation of the Complex Model beyond valid limits.

Availability of raw materials for ether production.

Availability and costs of imported ethers.

The vapor pressure of conventional gasoline.

Gasoline distillation specifications and engine operability with high percentages of ethers in gasoline.

Gasoline component blending properties.

Technology capability to process raw materials such as vegetable oils, and the quality of products of those technologies.

The accounting for low petroleum credit.

Distribution costs for ethanol.

The cost of capital.

Price assumptions.

Compared with summer gasolines, emissions constraints are less stringent for winter gasolines, and production costs are lower. If the winter gasoline production season is 6.5 months, then year-round low 
petroleum gasoline with near-30 percent non-petroleum components might be achieved by combinations of cases, with refining cost increases in the range of 23 to 37 cents per gallon of gasoline.

A refiner would not choose to produce low petroleum gasoline unless the average cost of crude in the base case is at least the cost of crude oil reduction in the low petroleum case. For year-round gasoline with near-30 percent non-petroleum components, crude oil use is reduced by 10 to 12 percent, at a cost $\$ 48$ to $\$ 89$ per barrel of crude. Depending upon resolution of uncertainties about extrapolation of the Complex Model, availability of raw materials and other issues, the cost increases could be lower or higher.

With the year-round low petroleum gasolines, there are greenhouse gas emissions changes between a 3 percent increase and a 16 percent decrease. The maximum estimated greenhouse gas reduction of 16 percent is achieved with use of cellulosic ethanol and with ethers produced from cellulosic ethanol.

A mix of strategies could be less costly than any of the cases examined in this study. For example, costs might be lower with production of regional mixes of ether-based and ethanol-based gasolines in the winter, and with mixes of ether-based gasolines in the summer. 


\section{LEGISLATIVE BASIS FOR LOW PETROLEUM GASOLINE}

In 1992, the Energy Policy Act (EPACT, P.L. 102-486) was enacted to provide a comprehensive national energy policy. One goal of EPACT is to increase U.S. energy security in ways that are both cost-effective and environmentally prudent. Consistent with this goal, one EPACT objective is to decrease U.S. dependence on foreign oil. To meet this objective, Section 502 of EPACT requires the Secretary of Energy to establish a program to determine the feasibility of reducing imported oil by 30 percent by the year 2010 .

A large part of the mandated reductions in foreign oil dependence is expected to be achieved by reducing the consumption of fuels for light duty motor vehicles, through the use of alternative and replacement fuels. Alternative fuels, such as ethanol, are those motor fuels that are "substantially not petroleum," being derived from sources other than crude oil.

A replacement fuel is also substantially not petroleum, but it replaces only a portion of a petroleumderived motor fuel. For example, ethanol is a replacement fuel in a gasoline containing 10 percent ethanol. EPACT requires the Secretary of Energy to determine the feasibility of producing sufficient replacement fuels to replace at least 10 percent of the projected consumption of motor fuels by light duty vehicles in the year 2000, and the feasibility of replacing at least 30 percent in the year 2010. EPACT also requires the Secretary to determine the greenhouse gas emission implications of increasing the use of replacement fuels.

In its marriage with petroleum-derived fuels, the replacement fuel concept depends on the continuing existence and technical development of the petroleum refining infrastructure. Gasoline is the predominant fuel for light duty vehicles, and this report focuses on refinery production of "low petroleum" gasolines. Like all highway gasolines, low petroleum gasolines must comply with requirements of the Clean Air Act.

\section{THE CLEAN AIR ACT AMENDMENTS OF 1990}

The Clean Air Act Amendments of 1990 (CAAA) include programs for oxygenated gasoline and for reformulated gasoline (RFG). The oxygenated gasoline program requires that, beginning November 1, 1992, gasoline with a minimum oxygen content of 2.7 weight (wt) percent must be sold during winter months in about 40 cities not in compliance with carbon monoxide standards. RFGs are required by January 1, 1995, in nine areas with extreme or severe ozone pollution problems. RFG formula and emissions performance standards are shown in Table 1.

Emissions modeling provides a means for predicting the emissions performance of a gasoline, given other properties of the gasoline. The Complex Model of the Environmental Protection Agency (EPA) is a set of equations that predicts emissions of VOCs, TAPs, and NOx in terms of gasoline properties including RVP, E200, E300, benzene, oxygen, sulfur, aromatics, and olefins contents. The Complex Model must be used after March 1, 1997, to certify the emissions performance of gasolines. 


\begin{tabular}{|c|c|c|}
\hline Standard & $\begin{array}{l}\text { Phase I CAAA standards } \\
\text { (beginning January } 1,1995 \text { ) }\end{array}$ & $\begin{array}{l}\text { Phase II Environmental } \\
\text { Protection Agency } \\
\text { final rule standards } \\
\text { (Beginning January } 1,2000 \text { ) }\end{array}$ \\
\hline Oxygen content & \multicolumn{2}{|c|}{2 wt percent minimum } \\
\hline Benzene content & \multicolumn{2}{|c|}{1 vol percent maximum } \\
\hline Additives & \multicolumn{2}{|c|}{ No additives with heavy metals } \\
\hline $\begin{array}{l}\text { Volatile Organic Compounds } \\
\text { (VOCs include all } \\
\text { oxygenated and non- } \\
\text { oxygenated hydrocarbons } \\
\text { except for methane and } \\
\text { ethane) }\end{array}$ & $\begin{array}{l}\text { Must be reduced by at least } 15 \\
\text { percent during the summer } \\
\text { high-ozone season, compared } \\
\text { with the calculated VOC } \\
\text { emissions from the use of the } \\
\text { statutory baseline gasoline. }\end{array}$ & $\begin{array}{l}\text { Must be reduced during the } \\
\text { summer by } 25.9 \text { percent on a } \\
\text { per-gallon basis or by } 27.4 \\
\text { percent on an averaged basis. } \\
\text { A greater percentage } \\
\text { reduction is required in } \\
\text { southern states. }\end{array}$ \\
\hline $\begin{array}{l}\text { Toxic Air Pollutants } \\
\text { (TAPs consist of } \\
\text { benzene, } 1,3 \text { butadiene, } \\
\text { formaldehyde, } \\
\text { acetaldehyde, and } \\
\text { polycyclic organic } \\
\text { matter) }\end{array}$ & $\begin{array}{l}\text { Must be reduced by at least } 15 \\
\text { percent during the entire year, } \\
\text { compared with the calculated } \\
\text { TAP emissions from the use of } \\
\text { the statutory baseline gasoline. }\end{array}$ & $\begin{array}{l}\text { Must be reduced year-round } \\
\text { by } 20 \text { percent on a per-gallon } \\
\text { basis or by } 21.5 \text { percent on an } \\
\text { averaged basis. }\end{array}$ \\
\hline Nitrogen Oxides (NOx) & $\begin{array}{l}\text { Must not increase relative to } \\
\text { the emissions of the statutory } \\
\text { baseline gasoline. }\end{array}$ & $\begin{array}{l}\text { Must be reduced during the } \\
\text { summer by } 5.5 \text { percent on a } \\
\text { per-gallon basis or by } 6.8 \\
\text { percent on an averaged basis. } \\
\text { Must not increase during the } \\
\text { winter on a per-gallon basis } \\
\text { and must be reduced by } 1.5 \\
\text { percent on an averaged basis. }\end{array}$ \\
\hline \multicolumn{3}{|c|}{$\begin{array}{l}\text { aFor the per-gallon standard, every gallon of every batch of RFG produced at the refinery must } \\
\text { meet the same emissions-performance requirements. For the averaged standard, different batches } \\
\text { may vary within limits, as long as the refinery's total RFG output meets the specified average } \\
\text { emissions performance requirement. }\end{array}$} \\
\hline
\end{tabular}


The nine areas in the extreme and severe ozone nonattainment categories currently comprise about 25 percent of the nation's gasoline market. However, because of the gasoline distribution system, surrounding areas may receive RFG as well. Other areas are allowed to petition the EPA to opt-in to the RFG program. States may decide that, compared with other alternatives, the best strategy for achieving compliance with clean air standards is to require the use of clean gasolines to reduce vehicular emissions. The total national market for RFG could exceed 60 percent by the end of the century. ${ }^{1}$

In fact, all gasolines will be affected by the CAAA. Besides requiring RFG in the covered ozone nonattainment areas, the CAAA require that gasoline in all other areas not be any more polluting than it was in 1990. Without this "anti-dumping" provision, the potential exists for emissions from conventional gasoline (CG) to worsen as polluting fuel components are removed from RFG.

\section{THE ORNL REFINERY YIELD MODEL}

\subsection{ORNL-RYM Capabilities}

The potential for low petroleum gasoline production has been analyzed with the Oak Ridge National Laboratory Refinery Yield Model (ORNL-RYM), a refinery linear program. ORNL-RYM is an enhanced personal computer version of the Refinery Yield Model of the Refinery Evaluation Modeling System. ${ }^{2-5}$

ORNL-RYM tracks octane, RVP, oxygen content, sulfur, benzene, aromatics, total olefins, distillation points, VOC, TAP, and NOx on all gasoline component streams. In separate data tables in ORNL-RYM, blending components for each gasoline grade are identified; blending values are assigned to over 140 components; and blending targets (i.e., specifications with blending margins) are set.

Properties for distillates and jet fuels are handled conceptually the same as for gasoline. Properties can include gravity, aromatics content, paraffins content; naphthenes content, sulfur content, freezing point, luminometer number (which is correlated with smoke point), heat of combustion, hydrogen content, light cycle oil content, hydrocracked stocks content, surface tension, pour point, cetane index, flash point, viscosities, RVP, distillation points, and diesel ignition improver content. The model also provides for jet fuel additives for anti-icing, corrosion inhibition, and other functions.

Changes in crude feedstock are described in tables for crude quantity and assay. ORNL-RYM includes 48 refining processes, which can be used to produce 40 different products from more than 100 crude oils. Individual process units can have several modes of operation, each mode with different feedstocks and different yields. An investment module provides for the addition of processing capacity. Potentially key processes in ORNL-RYM for the production of CAAA-compliant low petroleum gasolines are listed in Table 2. These processes are grouped in the table by functions which are important for:

- CAAA compliance (through reduction of RVP, benzene, sulfur, aromatics);

- Oxygenate production for CAAA compliance and low petroleum credit (through light olefins production and etherification). With the addition of processes like dehydrogenation and dimerization of ethylene, the refinery becomes "more petrochemical" in character.

- Hydrogenation for low petroleum credit. 


\begin{tabular}{|c|c|c|}
\hline Process & Function & Potential importance \\
\hline Naphtha hydrotreating & $\begin{array}{l}\text { Desulfurization, reformer feed } \\
\text { preparation }\end{array}$ & \multirow{5}{*}{ CAAA compliance } \\
\hline FCC feed hydrofining & $\begin{array}{l}\text { Desulfurization, FCC feed } \\
\text { preparation }\end{array}$ & \\
\hline Reformate splitting & $\begin{array}{l}\text { Separation of naphthas with high } \\
\text { benzene, high aromatics contents }\end{array}$ & \\
\hline $\begin{array}{l}\text { Alkylation/ } \\
\text { Alkylation of benzene }\end{array}$ & $\begin{array}{l}\text { Production of alkylate with low } \\
\text { emissions }\end{array}$ & \\
\hline Aromatics recovery & $\begin{array}{l}\text { Separation of naphthas with high } \\
\text { benzene, high aromatics content }\end{array}$ & \\
\hline $\begin{array}{l}\text { Fluid catalytic cracking/ } \\
\text { FCC gasoline splitting/ } \\
\text { Ether production }\end{array}$ & $\begin{array}{l}\text { Olefins production/ } \\
\text { Olefins separation/ } \\
\text { Ether production }\end{array}$ & $\begin{array}{l}\text { Satisfying CAAA } \\
\text { oxygenate standard and } \\
\text { for low petroleum credit }\end{array}$ \\
\hline Naphtha hydrocracking & Production of $\mathrm{C} 4 \mathrm{~s}$ from naphthas & \multirow{5}{*}{$\begin{array}{l}\text { Production of feedstocks } \\
\text { used to produce oxygenate } \\
\text { for low petroleum credit }\end{array}$} \\
\hline Butane isomerization & $\begin{array}{l}\text { Isomerization of normal } \mathrm{C} 4 \text { for } \\
\text { subsequent dehydrogenation }\end{array}$ & \\
\hline C2-C5 dehydrogenation & Production of light olefins & \\
\hline Thermal cracking (gas) & Production of light olefins & \\
\hline $\begin{array}{l}\text { Cryogenic fractionation/ } \\
\text { Dimerization of ethylene }\end{array}$ & $\begin{array}{l}\text { Recovery of ethylene/ } \\
\text { Production of butylene }\end{array}$ & \\
\hline Hydrogen production & $\begin{array}{l}\text { Hydrogen production from non- } \\
\text { petroleum source (natural gas) }\end{array}$ & \multirow{2}{*}{$\begin{array}{l}\text { Hydrogenation for low } \\
\text { petroleum credit. }\end{array}$} \\
\hline Gas oil hydrocracking & Production of naphthas & \\
\hline
\end{tabular}


ORNL-RYM can be used to represent various regional refining configurations. The model assumes that all refineries within a large region are interconnected. Consequently, ORNL-RYM has a tendency to over-optimize refinery operations. The over-optimization problem can be mitigated by focusing on changes in refining variables, rather than relying on the model to predict exact outcomes. When ORNLRYM is used to analyze novel refining scenarios, it is advisable to interpret results with a more qualitative perspective.

\subsection{Representation of Non-linear Emissions Models in a Linear Program}

ORNL-RYM represents gasoline blending to satisfy emissions constraints defined by EPA's final Complex Model. ${ }^{6}$ The non-linear Complex Model presents difficult adaptation problems for use in refinery linear programs. Each gasoline blending component has VOC, TAP, and NOx blending values that vary with overall gasoline composition. The Complex Model is represented in ORNL-RYM by the linear delta method shown in Table 3 . Off-line software computes $\triangle$ emissions/ $\triangle P R O P E R T Y$ coefficients. These coefficients are then used in the off-line software to compute emissions blending values for the gasoline blending components. ORNL-RYM is solved iteratively, until convergence of the coefficients. 
Table 3.

Complex model representation in ORNL-RYM by linear delta method

An emission value for NOx, VOC, TAP is represented as a base value plus small linear emissions changes dne to small changes in gasoline properties. NOx is illustrated with the Phase II Complex Model:

Step I: Choose a base gasoline. The base gasoline (for summer use in Region C) might have the following base PROPERTY values: $M T B E$ oxygen $=2.1 ; \mathrm{RVP}=7.2$; sulfur $=140$; aromatics $=25$; olefins $=10 ; \mathrm{E} 200=49.9$; $\mathrm{E} 300=85.1$; benzene $=0.7 ; \mathrm{NOX}=1240.89$.

Step 2: Develop the blending equation.

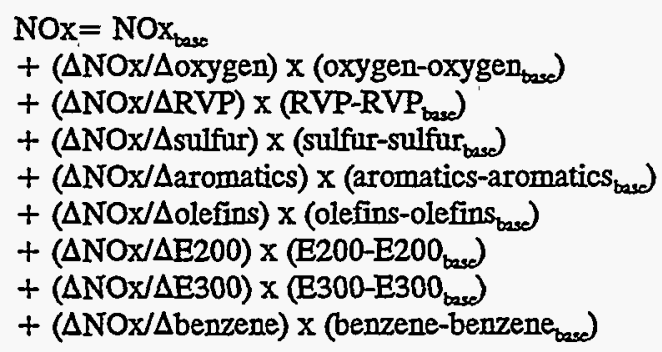

The $\triangle N O x / \triangle P R O P E R T Y$ is an original coefficient $\left(W_{\text {odginas }}\right)$. To determine ( $\Delta N O x / \Delta$ olefins) for the base gasoline in Step 1 (olefins $=10$ and $N O x=1240.89$ ), calculate NOx for that gasoline with olefins decreased by $0.1 \%$ (olefins $=9.9$ and $\mathrm{NOX}=1240.33$ ):

$$
(\Delta \text { NOx/Aolefins })=(1240.89-1240.33) /(10-9.9)=5.6
$$

Step 3: Solve the linear program using the NOx constraint equation. For example,

NOx $\leq 1232.8$ (for an 8 percent NOx reduction)

$$
\begin{aligned}
& \text { NOx }=1240.89 \\
& -1.31864 \times \text { (oxygen-2.1) } \\
& +3.65489 \times \text { (RVP-7.2) } \\
& +0.54643 \times \text { (sulfur-140) } \\
& +3.23156 \times \text { (aromatics-25) } \\
& +5.6 \times \text { (olefins-10) } \\
& +1.15442 \times(\text { E200-49.9) } \\
& -0.55387 \times(\text { E300-85.1) } \\
& +0 \times \text { (benzene-0.7) }
\end{aligned}
$$

Calculate the NOx values for each gasoline blendstock and load the values in a gasoline component blending table.

Step 4: Given the linear program solution PROPERTY values, calculate new coefficients $\left(W_{\text {acw }}\right)$. Compare the original $\left(W_{\text {criginal }}\right)$ and the new $\left(W_{\text {new }}\right)$ coefficients for each PROPERTY. At convergence, ACCEPT LINEAR PROGRAM SOLUTION and STOP. Otherwise, choose a new base gasoline with PROPERTY values equal to the linear program solution values, and Go to Step 2. 


\section{PREMISES FOR LOW PETROLEUM GASOLINE STUDY}

\subsection{Gasoline Performance Specifications}

The averaged basis standards for VOC and NOx are used in the low petroleum cases for the summer of year 2010. To provide allowances for enforcement compliance, refiners may add blending margins to the emissions standards. Table 4 shows the regionally weighted emissions targets, with and without arbitrary blending margins.

\begin{tabular}{||l|c|c||}
\hline \hline \multicolumn{2}{||c||}{$\begin{array}{c}\text { Table 4. Emissions performance targets for reformulated gasoline produced in } \\
\text { PADD In low petroleum study } \\
\text { (percent reductions relative to statutory baseline) }\end{array}$} \\
\hline Controlled emissions & $\begin{array}{c}\text { Standard weighted by } \\
\text { end-use region share }\end{array}$ & $\begin{array}{c}\text { Weighted standard plus } \\
\text { margin }\end{array}$ \\
\hline VOC & 28.4 & 30.0 \\
\hline NOx (summer) & 6.8 & 7.8 \\
\hline NOx (winter) & 0.0 & 1.0 \\
\hline TAP (summer) & 25.0 & 26.5 \\
\hline TAP (winter) & 15.8 & 16.8 \\
\hline
\end{tabular}

To satisfy the anti-dumping provision of the CAAA, CG is produced with no increase in emissions, relative to gasoline produced in PADD III in 1990. The 1990 model-derived summer gasoline properties for 1990 are compared to survey properties for 1989 in Table 5. For year 2010 CG, 1 percent margins are applied to the model-derived emissions properties. The maximum allowable RVP for summer CG is assumed to be 7.9 psi. ${ }^{b}$

${ }^{\mathrm{a}} 1990$ emissions for winter gasolines produced in PADD II are based on winter gasoline properties reported in reference 7.

'In the summer Base case (cost reference case), the 7.9 psi RVP specification for CG correctly represents standards of the current Phase II RVP program. However, a 7.9 psi RVP for summer CG is a misspecification for the full opt-in assumptions of the low petroleum cases. With allowance for blending margins, the CG RVP specification should be $8.7 \mathrm{psi}$, since CG is used in ozone attainment areas. The CG RVP misspecification was discovered after completion of model runs. In high oxygenation cases, the misspecification does not matter, because the CG RVP is not a binding constraint. An $8.7 \mathrm{psi}$ RVP sensitivity case is examined for the case with the highiest cost of RVP reduction. Marginal costs of RVP reduction are used to estimate refining costs for the other cases with CG RVP changed to $8.7 \mathrm{psi}$. 


\begin{tabular}{|c|c|c|}
\hline \multicolumn{3}{|c|}{$\begin{array}{l}\text { Table } 5 \text {. } \\
\text { Historical PADD III summer gasoline properties }\end{array}$} \\
\hline & 1990 RYM & $\begin{array}{c}1989 \\
\text { Survey }^{8,9}\end{array}$ \\
\hline$(\mathrm{R}+\mathrm{M}) / 2$ & 89.1 & $87.2-92.6$ \\
\hline Aromatics, vol \% & 33.3 & 31.6 \\
\hline Oxygen, wt \% & 0.22 & 0.22 \\
\hline Olefins, vol \% & 12.2 & 13.2 \\
\hline Benzene, vol \% & 1.53 & 1.64 \\
\hline Sulfur, ppm & 314 & 305 \\
\hline RVP, psi & 9.4 & 9.4 \\
\hline $\mathrm{E} 200$, vol \% & 44.0 & 44.0 \\
\hline $\mathrm{E} 300$, vol \% & 88.4 & 80.5 \\
\hline API gravity & 59.5 & $56.4-59.3$ \\
\hline $\mathrm{NOx}, \mathrm{mg} / \mathrm{mi}$ & 1360 & 1365 \\
\hline $\mathrm{TAP}, \mathrm{mg} / \mathrm{mi}$ & 80.0 & 80.1 \\
\hline $\mathrm{VOC}, \mathrm{mg} / \mathrm{mi}$ & 1588 & 1596 \\
\hline
\end{tabular}




\subsection{Product and Crude Slates}

ORNL-RYM has been used to study low petroleum gasoline production in Petroleum Administration for Defense District III (PADD III, the U.S. Gulf Coast) during the year 2010. It is assumed that seasonal gasoline and distillate demand will be the same as in 1989, with gasoline demand adjusted to account for fuel economy differences, and with full opt-in by ozone non-attainment areas. ${ }^{10,11}$ RFG production is assumed to be 62 volume percent of total gasoline production. It is also assumed that 60 percent of RFG produced in PADD III will be consumed in region 1 (typically northern areas), and 40 percent will be consumed in region 2 (typically southern areas). ${ }^{12}$

Total product output is fixed, except for coke and sulfur production. For the low petroleum cases, crude quality is constant. Recently reported crude quality is compared to crude quality in the low petroleum study in Table 6.

\begin{tabular}{||l|c|c||}
\hline \multicolumn{1}{||c|}{ Table 6. Quality of crude oil processed by PADD III refineries } \\
\hline & $\begin{array}{c}\text { Year 1993, actual } \\
\text { annual }^{13}\end{array}$ & $\begin{array}{c}\text { Low petroleum } \\
\text { assumption }\end{array}$ \\
\hline Sulfur, wt percent & 1.23 & 1.64 \\
\hline Gravity, ${ }^{\circ} \mathrm{API}$ & 32.37 & 31.98 \\
\hline \hline aQuality estimated by extrapolation to year 2000 \\
\hline
\end{tabular}

\subsection{Limits on Transportation Fuel Properties}

The specifications for low petroleum gasoline need to be generally compatible with the ASTM D486 specifications. Some important considerations include: ${ }^{14}$

Octane: ASTM D-486 sets an octane limit for the average of Research and Motor Octane $(\mathrm{R}+\mathrm{M}) / 2$, by grade of gasoline. However, the octane sensitivity, R-M, can be an issue with some blends. The sensitivity minimum specification of 7.5 must be augmented with a maximum sensitivity specification of about 15 . The maximum specification will avoid problems with knock in particular operating regimes, and is derived from research on methanol which has a high sensitivity.

Reid Vapor Pressure: The RVP is a measure of gasoline volatility, and the RVP specification varies seasonally and geographically. RVP reduction is the most cost-effective mechanism for reducing VOC in summer gasolines. In many cases, RVP will be driven to a lower limit to satisfy the RFG VOC specification. The assumed lower limits are 6.5 for summer and 11.6 for winter, below which there are operability concerns because of insufficient fuel volatility.

Distillation Curve: For the low petroleum study, the distillation temperature ranges for summer RFG have been set at the combined limits for California Phase I and Phase II RFGs. The allowable range for $\mathrm{T} 50$ is 200 to $230^{\circ} \mathrm{F}$, and 290 to $325^{\circ} \mathrm{F}$ for $\mathrm{T} 90$. These ranges correspond to approximately 35 to 50 percent for E200, and 84 to 92 percent for E300. The distillation ranges for winter gasolines have been set to recently reported maximum and minimum values. ${ }^{15}$ 
Oxygen Content: The maximum allowable oxygen content is currently 3.5 wt percent for ethanol blends. However, modern vehicles can generally perform adequately with oxygen levels of 5 to $6 \mathrm{wt}$ percent. In the low petroleum cases, the maximum allowable oxygen content is 6 wt percent. Extrapolation assumptions are required for use of the Complex Model beyond its valid limit of 3.7 wt percent oxygen.

Energy Content: BTU content is not the sole determinant of fuel economy. Other characteristics of the fuel; as well as vehicle related factors, may also affect fuel economy. Although oxygenates contain less energy than some other gasoline components, their presence in gasoline chemically enleans the air/fuel charge, which can result in more complete combustion of fuel. Depending upon vehicle technology, this improvement in combustion may compensate for the lower BTU value. ${ }^{16}$ The costs of fuel economy changes are included in the refining costs for low petroleum gasoline production. These costs could be high because they are based solely on energy content. However, the fuel economy cost effect in the low petroleum cases is usually small compared to the refining cost effects.

Hydroprocessing may be very important in some low petroleum gasoline production cases, with possible side effects on the amounts of severely hydroprocessed stocks blended to distillates. Therefore, specifications have to be imposed on some distillate products to prevent problems with fuel stability and lubricity.

Stability: Light cycle oils (LCOs) are important blendstocks for diesel fuels. LCOs have inferior stability, with tendencies to produce gums and other particulates, resulting from complex interactions between molecular oxygen, and organic compounds containing-nitrogen/sulfur/oxygen, reactive olefins, and aromatics compounds. The resulting particulates and gums can cause plugging of diesel engine filters and fouling of fuel injectors. ${ }^{17}$ Research has shown rapid degradation in the stability of fuels blended with more than 30 percent LCO in virgin distillate. Therefore, in the low petroleum study, the maximum allowable LCO in highway diesel fuel has been set at 30 percent. ${ }^{18,19}$

Lubricity: Severely hydroprocessed blendstocks could be important in the low petroleum hydrogenation strategies. Severe hydroprocessing can remove naturally occurring impurities such as organic acids and some polynuclear hydrocarbons which impart good lubricity. Poor lubricity military jet fuels have caused wear problems with fuel pumps and fuel control valves. Corrosion inhibiting additives can mitigate lubricity problems. However, to provide additional protection against the lubricity problem in the low petroleum study, upper limits have been placed on the percentage of severely hydroprocessed stocks that can be blended to jet fuels ( 15 percent for military fuels and 45 percent for civilian fuels). ${ }^{20}$

\subsection{Raw Material and Product Value Assumptions}

The PADD III refiner price for crude oil is assumed to follow the supply curve in Fig. 1. The derivation of the supply curve is explained in Appendix A. The curve is based on a long-run supply elasticity of 0.3 and a reference crude oil price of $\$ 26.49$ per barrel (1990 U.S. dollars) for the year $2010 .^{21}$ The crude oil price is used to estimate prices for individual refined products, such as those listed in Table 7. The price differentials for the products in Table 7 have remained nearly constant in recent decades, despite a tenfold range of crude oil prices. ${ }^{22}$ Ether prices are based on National Petroleum Council estimates. ${ }^{23}$ 
The PADD III refiner price for natural gas is assumed to follow the supply curve in Fig. 2. The derivation of the supply curve is explained in Appendix A. The curve is based on a long-run supply elasticity of 0.3 and an average dry gas price of $\$ 3.17$ per MCF (1990 U.S. dollars) for the year 2010. ${ }^{21}$

The PADD III refiner price for corn-derived ethanol is assumed to follow the supply curve in Fig. 3. The derivation of the supply curves for both corn-derived and cellulosic ethanol is explained in Appendix A. The ethanol supply curves include the federal tax credit of 54 cents per gallon.

In the production of low petroleum gasoline, natural gas is often substituted for crude oil. Because of increased gas demand, the price of natural gas increases. With decreased demand for crude oil, the price of crude oil falls. Product prices are affected by a price reduction driven by the falling crude oil price, and a price increase due to the increased costs of natural gas and refining. The low petroleum study assumes that the demand for refined products is constant, regardless of the net price effect. In actual markets, the demand could change with changes in price. The sensitivity of price assumptions is gauged by reporting results for all low petroleum cases in terms of the assumptions stated above ("the elastic price assumption") and for a constant price assumption.

\begin{tabular}{||l||l||}
\hline \multicolumn{2}{|c||}{ Table 7. Product price differentials ${ }^{22}$} \\
\hline \multicolumn{1}{|c||}{ Product } \\
\hline Unleaded premium gasoline & \multicolumn{1}{|c||}{ Relationship } \\
\hline Unleaded regular motor gasoline & 4.0 cents per gallon over unleaded regular motor gasoline \\
\hline Jet A & 3.5 cents per gallon over No. 2 fuel oil \\
\hline No. 2 fuel oil & 3.0 cents per gallon over No. 2 fuel oil \\
\hline No. 6 fuel oil (0.7\% sulfur) & $8 \%$ over crude oil \\
\hline Bunker fuel (3\% sulfur) & $77 \%$ of No. 2 fuel oil \\
\hline
\end{tabular}

\subsection{Treatment of Capital Cost Recovery}

Capital equipment investment is based on a 15 percent discounted cash flow rate of return on investment (ROI), with account for seasonal process utilization changes. Other studies have used a 15 percent ROI to select optimal process investments, with actual costs based on a 10 percent ROI. ${ }^{24}$ The sensitivity of the ROI assumption is discussed in reference 25 .

\subsection{Base Cases (Cost Reference Cases)}

Refining costs (and fuel economy cost effects) are relative to year 2010 seasonal base cases with production of 100 percent $C G$. The Base cases (cost reference cases) use current refinery capacity plus additional (sunk cost) investment capacity. ${ }^{13}$ Summer Base case gasoline blendstocks and properties are shown in Tables B-1 and B-2. Winter Base case gasoline blendstocks and properties are shown in Tables D-1 and D-2. 


\section{LOW PETROLEUM GASOLINE COMPONENTS}

EPACT defines replacement fuel as "the portion of any motor fuel that is methanol, ethanol, or other alcohols, natural gas, liquified petroleum gas, hydrogen, coal derived liquid fuels, fuels (other than alcohol) derived from biological materials, electricity (including electricity from solar energy), ethers, or any other fuel the Secretary [of Energy] determines, by rule, is substantially not petroleum and would yield substantial energy security benefits and substantial environmental benefits."

For the study of low petroleum gasoline production, it is assumed that replacement fuels can become a portion of gasoline by direct blending or by conversion into another form which can be blended into gasoline. For example, ethanol can be blended as is. Hydrogen (derived from "non-petroleum" natural gas and steam) cannot be directly blended into gasoline, but it can enter gasoline in a converted form (for example, through hydrogenation of unsaturated hydrocarbons). Fig. 4 illustrates how the replacement petroleum concept could be merged with conventional refining processes. The low petroleum study investigates replacement of petroleum by:

- Direct blending or conversion of alcohols:

Methanol (derived from natural gas) and ethanol can be directly blended into gasoline for replacement fuel credit. Gasoline grade tertiary butyl alcohol (GTBA) is directly blended as a cosolvent with methanol. Methanol and ethanol can also be converted into ethers.

- Direct blending of ethers:

Replacement fuel credit is given for purchased methyl tertiary butyl ether (MTBE) and ethyl tertiary butyl ether (ETBE), which are assumed to be derived from non-petroleum sources.

For ethers produced in the refinery, the associated alcohol is credited as a replacement fuel. Produced ethers can include MTBE, tertiary amyl methyl ether (TAME), tertiary hexyl methyl ether (THME), ETBE, tertiary amyl ethyl ether (TAEE), and tertiary hexyl ethyl ether (THEE).

- Hydrogenation:

Hydrogen derived from non-petroleum sources and used in hydrogenation processes can be credited as a replacement fuel in gasoline. However, as shown in Appendix C, there should be deductions for hydrogen used in desulfurization, fuel gas, and in hydrogenation of blendstocks for products other than low petroleum gasoline.

- Conversion of vegetable oil:

It is assumed that rapeseed oil can be used as a feedstock for future cracking technologies. The rapeseed oil component of gasoline blendstocks is credited as replacement fuel. 
Replacement fuel credit is also given for purchased components of natural gas liquids (NGLs include ethane, propane, butanes and natural gasoline). ${ }^{2}$ These non-petroleum components may be used in the production of ethers, alkylate, reformate and other gasoline blendstocks. If large volumes of ethers are used in low petroleum gasoline, production costs could be particularly sensitive to the availability of NGL component raw materials for ether production.

\subsection{NGL Composition}

Natural gas is composed of methane with some entrained light hydrocarbons. NGLs are produced when the non-methane components are extracted from natural gas. The methane portion of produced natural gas varies widely from one deposit to another, and could range from 50 to 99 percent. The remaining 1 to 50 percent is NGLs and other contaminant gases such as carbon dioxide, hydrogen, and nitrogen. On average nationwide, 9 percent of natural gas is NGLs.

Typically, NGLs are about 52 percent ethane, 27 percent propane, 13 percent butane, 5 percent pentane, and 3 percent hexane or heavier hydrocarbons. ${ }^{26}$

\subsection{Location and Quantity of NGLs}

Natural gas is processed at natural gas plants and at refineries. There are approximately 730 natural gas processing plants and 190 refineries in the United States. ${ }^{27}$ Gas processing plants account for about 74 percent of NGL production. ${ }^{28}$ Refinery-produced NGLs are crude-derived and are not credited as replacement fuel in this analysis. Gas plant production of propane, the primary commercial NGL, occurs in all gas-productive areas. Refinery production is concentrated in the Gulf area, but it is regionally important in the vicinity of other refinery centers such as Philadelphia, Chicago, and the West Coast. Natural gas and NGL users include petrochemical plants (the largest single user), refineries, other industry, residential, utility, commercial, and agricultural sectors. ${ }^{27}$ Over the last 20 years, daily production of NGLs in gas processing plants has averaged about 1.5 million barrels per day. ${ }^{29}$ Current domestic daily production of NGLs is about 1.75 million barrels per day or 640 million barrels per year..$^{30}$

Historically, 3 to 5 percent of natural gas has been imported. As recent domestic natural gas demand has risen faster than production, imports are now 9 to 11 percent. Natural gas imports result in the elimination of some volume of NGLs, which would be coproduced if a volume of natural gas equivalent to the imported volume were processed domestically. To the extent that increased demand for natural gas is supplied by imports, some historical volume of NGLs will be lost.

Natural gasoline is considered a replacement fuel in this analysis because it is "substantially not petroleum" as required by EPACT and is a logical technical interpretation of the intent of the law. Liquified petroleum gases, explicitly mentioned in the EPACT definition, include ethane, propane, and butanes produced from natural gas processing. 


\subsection{NGL Quality}

"Quality" refers to the relative lack of non-hydrocarbon impurities in natural gas and NGLs. The composition of wellhead natural gas production varies widely. To meet pipeline requirements, wellhead natural gas must often be processed to remove water, NGLs, and non-hydrocarbon gases such as carbon dioxide, hydrogen sulfide, and nitrogen. While technologies exist for removing all common non-methane diluents from natural gases, the processes can be costly and energy intensive, especially when the diluents constitute a large percentage of the gas. criteria: ${ }^{31}$

"Subquality" natural gas is characterized by one or more of the following wellhead composition

- Carbon dioxide greater than or equal to 2 percent

- Nitrogen greater than or equal to 4 percent

- Hydrogen sulfide greater than or equal to $4 \mathrm{ppm}$.

These categories of gas composition generally require some form of upgrade (processing or blending). Carbon dioxide and hydrogen sulfide, termed "acid gases," are corrosive in pipelines and must be removed when present in even small concentrations. Nitrogen is inert and reduces the heating value of the gas. Removing these impurities to produce pipeline-quality natural gas generates NGLs.

The amount of NGL in natural gas varies with gas type. Associated natural gas, which is found along with crude deposits, typically is higher in NGL content. It is often referred to as "rich" or "wet" gas. Non-associated natural gas is not found alongside crude deposits and tends to be "drier," meaning that the gas contains a lower percentage NGL. Since crude oil production is expected to decrease in the future, less associated natural gas will be produced as well. The trend in natural gas production is toward drier, non-associated gas.

\subsection{NGL Extraction/Production Methods and Associated Costs}

Gas processing plants have three basic methods of recovering NGLs from natural gas: straight refrigeration, cryogenic refrigeration and lean oil absorption. ${ }^{32}$ The first two methods are more common, with lean oil absorption used primarily in older plants.

\subsubsection{Straight Refrigeration}

The basic process for extracting NGLs from natural gas is cooling. In straight refrigeration, liquidladen gas is cooled to a temperature between $15^{\circ} \mathrm{F}$ and $-40^{\circ} \mathrm{F}$. The lower temperatures are required to remove ethane. About 70 percent of the ethane, 90 percent of the propane, and all of the butanes and pentanes can be recovered through this method. At the higher temperature, 25 to 35 percent of the ethane, 55 to 70 percent of the propane, 80 to 90 percent of the butanes, and at least 97 percent of the pentanes and heavier molecules can be recovered. A 20 million cubic foot per day. (inlet) straight refrigeration plant processes gas at a cost of about $\$ 0.05$ per thousand cubic feet (MCF). 


\subsubsection{Cryogenic Refrigeration}

To achieve greater extraction of ethane, lower temperatures are required than can be achieved through straight refrigeration. Cryogenic refrigeration temperatures can reach between $-150^{\circ} \mathrm{F}$ and $225^{\circ} \mathrm{F}$. With these temperatures, about 90 to 95 percent of the ethane and all of the heavier hydrocarbons can be recovered from natural gas. Natural gas is supercooled in a cryogenic unit by increasing the pressure on the gas. This can be done with either a turbo-expander or a Joule-Thomson valve. A 20 million cubic foot per day (inlet) cryogenic refrigeration plant processes gas at a cost of about $\$ 0.03$ per MCF.

The economics of the straight refrigeration plant versus the cryogenic refrigeration plant depend on the volume of gas to be processed, the amount of NGL present in the gas, the pressure of the incoming gas source, and the intended use of the recovered liquids. Generally, straight refrigeration plants are more economical if a small volume of gas is to be processed, and cryogenic plants are more economical if the gas stream to be processed has a lower NGL content. Since the trend is toward drier gas with a lower NGL content, only use of low-temperature straight refrigeration or cryogenic refrigeration will extract the maximum amount of NGLs from natural gas. From 1991 to 1992, there was a decline in production of ethane as the price of natural gas rose and margins narrowed that in turn decreased production of NGLs. Strong demand for ethane from the petrochemical sector is expected to improve margins in the late 1990s, which should benefit the production of heavier NGLs.

Although the economics of processing leaner gas are generally better in a cryogenic refrigeration plant, there is relatively little benefit to using low-temperature, deeper extraction processing methods to extract more of the heavier NGLs, since even the higher temperature straight refrigeration processing extracts most of the heavier hydrocarbons.

\subsection{NGL Transportation Modes and Associated Costs}

Small gas processing plants are often unable to fractionate the NGL stream completely. In the case where it is desirable to separate heavier products from the propane stream, the mixed NGL stream is sent to a fractionation center. There are two major storage and fractionation centers in the United States. One is at Mont Belvieu, Texas, and the other is in Conway, Kansas. The fractionation centers are connected to gas processing plants by an extensive pipeline system. There are currently 10 major pipelines with 72,000 miles of lines dedicated to moving NGLs. ${ }^{32}$ The average time to move product from Gulf Coast to midwest is 4 to 7 days.

The cost of transporting NGL to Mont Belvieu or Conway and then fractionating it ranges from $\$ 0.03$ to $\$ 0.10$ per gallon, with the higher costs associated with transporting from the Rocky Mountains or the northeastern part of Utah. ${ }^{32}$ With recently low NGL margins, the cost of moving NGL from some remote regions to the Gulf Coast for fractionation makes it unprofitable to recover heavier NGLs.

After processing, the separated NGL products are transported from the fractionation center to end users or distributors. Generally, only petrochemical plants and refineries receive NGLs directly from the pipeline. Transport trucks or rail cars deliver to utility, industrial, and commercial users (including distributors). The type of transport used depends on the requirements of the specific NGL. Ethane is limited to pressurized pipeline movement because of its high vapor pressure and low density. Propane, butane, and natural gasoline may be moved by any of the above methods. Propane, perhaps the most marketable product in terms of variety of end uses, is often segregated and sold separately from butane 
and pentane. Butane, formerly used by refiners to "blend up" gasoline for higher octane, is used widely to make ethers.

\subsection{Projection of Future Resource Availability}

The future availability of NGLs for low petroleum gasoline does not show significant growth for four key reasons. First, current gas processing techniques are already extracting most of the butanes and heavier hydrocarbons in NGLs. Second, since the trend in future natural gas production is toward drier gas, there will be fewer NGLs in the gas that is processed domestically. Third, future increases in natural gas imports to meet increased natural gas demand does not provide any opportunity to increase the production of NGLs. Fourth, the Energy Information Administration predicts traditional demand for NGLs will remain flat through the year $2010 .^{33}$

In summary, no significant increase in production of NGLs is expected from natural gas processing plants. Any additional NGLs used to produce ethers would likely have to come from refineries or imports. 


\section{PRODUCTION OF LOW PETROLEUM SUMMER GASOLINE}

The low petroleum study does not provide forecasts of the volumes or mix of low petroleum gasolines that will enter the marketplace. Rather, the study examines hypothetical low petroleum gasoline formulations. These low petroleum gasolines are produced by direct blending or conversion of alcohols, direct blending of ethers, hydrogenation, and conversion of vegetable oil.

\subsection{Direct Blending of Alcohols}

\subsubsection{Methanol}

With EPA's phasedown of lead in gasoline, there was increased interest in the potential of methanol as an economical replacement for lost octane. In the late 1970s and early 1980s, EPA approved several blends of methanol in gasoline. Correctly produced methanol blends were attractive because they could be substituted for costly gasoline without expensive changes to either automobiles or fuel transport systems.

Without a cosolvent blended with methanol, water can separate from gasoline and accumulate at the bottom of storage tanks. When this water-rich mixture is pumped into an automobile's fuel system, it causes rough idling, stalling, and other problems. Publicity about incorrectly blended methanol contributed to automakers' skepticism about the effect of methanol blends on the engine and fuel system. As a result, several automakers cautioned motorists against using methanol blends and declared that vehicle warranties could be revoked if methanol blends were used. Higher methanol prices and misblending episodes led to the phase out of major methanol programs in the mid-1980s. ${ }^{34}$

Table 8 shows that methanol (with cosolvent) blends have attractive octane blending values, but high RVP blending values. RVP is the major determinant of VOC emissions. Fig. 5 shows that the VOC emissions blending value of methanol (with cosolvent) can be two and a half times the target VOC value for RFG. The RFG VOC specification greatly reduces the viability of methanol as a replacement fuel for gasoline. In fact, for premises of the low petroleum gasoline study, the minimum oxygen requirement for summer RFG cannot be met with methanol without exceeding the VOC emissions limit. Therefore, direct blending of methanol is eliminated as an option in the low petroleum study, but methanol remains important as a non-petroleum feedstock for ether production. 


\begin{tabular}{||l|c|c||}
\hline \multicolumn{3}{|c|}{ Table 8. Octane and RVP for RFG and blendstocks } \\
\hline & Octane, $(\mathrm{R}+\mathrm{M}) / 2$ & RVP, psi \\
\hline \hline Summer RFG & 88.6 (minimum) & $6.5-7.0$ (typical) \\
\hline $\begin{array}{l}\text { Methanol (with cosolvent gasoline grade tertiary } \\
\text { butyl alcohol, GTBA) }\end{array}$ & 107 & $34+$ \\
\hline Ethanol & 115 & 19.5 \\
\hline MTBE & 109 & 9 \\
\hline ETBE & 112 & 4 \\
\hline \hline $\begin{array}{l}\text { aRFG octane is target specification. RFG RVP is typical value range. Other octane and } \\
\text { RVP values are blending values. Blending values can vary with gasoline composition. }\end{array}$ \\
\hline
\end{tabular}

\subsubsection{Ethanol}

Ethanol has seen continued growth as a gasoline component since the late 1970s when it was used as a product extender due to tight gasoline supplies. State and federal benefits can be claimed if a renewable feedstock is used for ethanol production. The current federal excise tax credit is 5.4 cents per gallon of 10 percent ethanol in gasoline, or 54 cents per gallon of ethanol. The excise tax credit can be prorated below the 10 percent ethanol blend. Income tax credits can be claimed for ethers produced from ethanol, if the taxpayer is not paying the Alternate Minimum Tax. ${ }^{35,36}$

More than 95 percent of ethanol is made from corn, and about 6 percent of U.S. corn is used to make ethanol. ${ }^{37}$ However, cellulosic ethanol could have substantial cost and emissions benefits in the future. Production of cellulosic ethanol from low-cost and widely available materials, such as wood, could be a long-term solution to the problem of dwindling petroleum reserves, provided no fossil fuel inputs are used during biomass production, harvesting, and transport. It has been argued that use of cellulosic ethanol will result in no net contribution of carbon dioxide $\left(\mathrm{CO}_{2}\right)$ to the atmosphere. This is because the $\mathrm{CO}_{2}$ released during biomass conversion to ethanol and ethanol combustion will be absorbed during the growth of new biomass materials to replace those used during conversion. ${ }^{38}$ Other factors that could contribute to lower emissions of $\mathrm{CO}_{2}$ in the use of cellulosic ethanol include reduced use of fertilizers, pesticides, tillage, and labor.

Gasoline suppliers tend to blend ethanol into gasoline at sites near ethanol producers, predominantly in the Midwest for corn-derived ethanol. Most petroleum pipelines will not carry ethanol or ethanol blends, due to solvency properties. Ethanol can dissolve accumulated sediments, which could reform at valves and other critical points, or in vehicle engines. Pipelines and terminals would need to provide costly treatment to remove impurities and moisture, or need to replace fittings to permit transportation of ethanol or ethanol blends. Therefore, ethanol is usually shipped by truck or rail and blended with gasoline at distribution points, rather than at refineries. ${ }^{39}$ 
Ethanol-based gasoline demand can be very high in the low petroleum study. Extensive production and marketing would require the introduction of ethanol into pipeline systems. Anhydrous facilities would have to be provided from the point of blending to the point of retail sale. The American Petroleum Institute (API) has estimated that a 10 percent ethanol blend for half the gasoline sold would require an investment of $\$ 0.8$ to $\$ 1.7$ billion for upgrading blending, storage and pipeline systems. Annualized capital and operating costs would be about 21 to 24 cents per gallon of ethanol, or about 2 cents per gallon of the ethanol gasoline blend. ${ }^{39}$

As shown in Table 8, ethanol has an attractive octane blending value, but its RVP blending value is considerably higher than the likely RVP of RFG. Ethanol's RVP causes its VOC blending value to be high, as shown in Fig. 5. Another potential problem with ethanol is that RVP can increase through commingling of ethanol-based gasolines with other gasolines (the blending RVP of ethanol can increase as the ethanol concentration decreases). The current.maximum allowable concentration of oxygen from ethanol is $3.5 \mathrm{wt}$ percent, equivalent to 10 volume percent of ethanol. In the year 2010 low petroleum cases, the regulatory limit on oxygen is relaxed.

Six cases have been examined in which summer gasoline is oxygenated with ethanol. The nonpetroleum share is manipulated in these cases by increasing the oxygen content of gasolines, by decreasing the refinery input of crude oil, and by increasing the use of hydrogen. Sensitivity cases gauge the importance of the VOC and RVP assumptions. Given the large volumes of ethanol-based gasolines, the cases assume that ethanol blending is optimized and performed at the refinery. Major investments in the distribution system would be required to deliver these gasolines to end users. Distribution system investment costs are not included in the estimated refining costs. Tables 9 and 10 summarize case conditions, non-petroleum inputs, and refining costs. Key points related to these tables include:

Refining cost is sensitive to the VOC specification assumption. If the required VOC reduction is relaxed from 30 to 24 percent, the refining cost increase can be cut about half (compare cases $1 \mathrm{EA}$ and $2 \mathrm{EA})$.

Refining cost can be sensitive to the RVP specification assumption for CG. RVP for CG is a binding constraint in all ethanol cases. Among all low petroleum cases, RVP reduction is most costly in case 4EA. As a variation of case 4EA, case 5EA shows a refining cost decrease of 4 to 5 cents per gallon of gasoline when the allowable RVP for CG is increased to 8.7 psi.

In terms of increased refining costs, crude oil reduction can be expensive in ethanol blends (compare cases 3EA and 4EA). Low-RVP blend stocks are important in compensating for ethanol's high VOC blending value. Reducing crude input reduces the availability of low-RVP stocks.

The cost of crude oil reduction is the total increase in costs divided by the total reduction in crude oil use. A refiner would not choose to produce low petroleum gasoline unless the average cost of crude in the base case is at least the cost of crude oil reduction in the low petroleum case. In terms of the cost of crude oil reduction, the cases have similar cost-effectiveness. The lowest cost of crude oil reduction is for the CG RVP sensitivity case 5EA.

Crude oil reduction causes an increase in natural gas used as feed to the hydrogen plant (compare cases $3 \mathrm{EA}$ and $4 \mathrm{EA}$ ). 
Forced hydrogenation causes an increase in natural gas used as feed to the hydrogen plant (compare cases $3 \mathrm{EA}$ and $6 \mathrm{EA})$.

Oxygen levels slightly higher than those shown in the table are not feasible, because there is no market disposition for some naphthas displaced from gasoline. The displacement of naphthas is related to VOC control.

The maximum non-petroleum share is 17 to 18 percent, occurring with high crude oil reduction (cases $4 \mathrm{EA}$ and $5 \mathrm{EA}$ ).

Refining costs are sensitive to assumptions about price elasticity of raw materials and products. In case 5EA with corn-based ethanol, the refining cost increases range from 23 cents (constant prices) to 34 cents (elastic prices) per gallon of gasoline.

Refining costs are sensitive to assumptions about the use of corn-derived and cellulosic ethanol. In case 5EA, the use of cellulosic ethanol can save 3 to 5 cents per gallon compared to the use of corn-derived ethanol.

Gasoline blendstocks (Tables B-3 and B-4), gasoline properties (Tables B-5 and B-6), process capacity investments (Table B-7), and refinery fuel use changes (Table B-8) are shown in Appendix B. Key points related to these tables are:

In crude oil reduction, increased alkylation is required to compensate for the loss of low-RVP inputs (compare cases 3EA and 4EA). Increased natural gas feedstocks are used in expanded hydrogen plant capacity. The increased hydrogen stream is utilized in expanded hydrocracker capacity. There are increases in hydrocrakate blended to gasolines and to distillates (Table 11).

A reduction of crude oil (with reduced availability of low RVP stocks) causes a shift of refinery operations toward building larger molecules from small molecules. For example, lighter hydrocarbons are separated by fractionation and combined in processes such as alkylation, dimerization, and polymerization (compare cases $1 \mathrm{EA}$ and $3 \mathrm{EA}$ ).

Forced hydrogenation causes an increase in natural gas used as feed to expanded hydrogen plant capacity (compare cases 3EA and 6EA). The increased hydrogen output is utilized in expanded hydrocracker capacity. There are increases in hydrocrakate blended to gasolines and to distillates (Table 11).

For comparable cases (EA and 4EA), forced hydrogenation increases the share of hydrogen credited to low petroleum gasoline. However, the maximum hydrogen credit occurs in case 5EA. In the low petroleum study, there are relatively loose constraints on the disposition of hydrogen. Given the method for crediting hydrogen as a replacement fuel (Appendix $\mathrm{C}$ ), the share of hydrogen could be increased by imposing a constraint on hydrocracked stocks blended to all distillates.

With increased hydrogen production (compare cases 3EA and 6EA) and molecular conversions (compare cases 3EA and 4EA), refinery fuel use increases.

The ethanol cases fall short of the 30 percent replacement goal of EPACT. Section 7 will compare the potential of ethanol strategies with replacement of petroleum by other methods. 


\begin{tabular}{|c|c|c|c|c|c|c|c|}
\hline 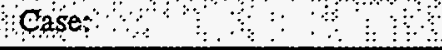 & Base & $1 \mathrm{BA}$ & 2EA & $3 \mathrm{EA}$ & $4 \mathrm{EA}$ & SEA & $6 \mathrm{EA}$ \\
\hline RFG oxygen target, wt\% & & 2.1 & 2.1 & 2.7 & 2.7 & 2.7 & 2.7 \\
\hline CG oxygen target, wt\% & & & & 3.5 & 3.5 & 3.5 & 3.5 \\
\hline Crude reduction target, vol\% & & & & 10 & 15 & 15 & 10 \\
\hline Forced hydrogenation? & & No & No & No & No & No & Yes \\
\hline RFG VOC reduction, min\% & & 30 & 24 & 30 & 30 & 30 & 30 \\
\hline CG RVP, $\max p s i$ & & 7.9 & 7.9 & 7.9 & 7.9 & 8.7 & 7.9 \\
\hline Components & & 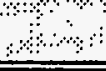 & \% & & ৪: & 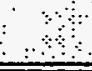 & \% \\
\hline Crude, MBD & 6135 & 6089 & 6009 & 5521 & 5215 & 5215 & 5521 \\
\hline Crude reduction, vol\% & & 0.7 & 2.0 & 10.0 & 15.0 & 15.0 & 10.0 \\
\hline $\begin{array}{l}\text { Hydrogen from natural gas, } \\
\text { MBD (GE) }\end{array}$ & 6.7 & 29.8 & 27.3 & 41.5 & 79.5 & 79.7 & 54.3 \\
\hline Natural gasoline, MBD (GE) & 96.1 & & 1.1 & 96.1 & 96.1 & 96.1 & 96.1 \\
\hline Ethane, MBD (GE) & 2.8 & 2.8 & 2.8 & 2.8 & 2.8 & 2.8 & 2.8 \\
\hline Propane, MBD (GE) & 6.4 & 6.4 & 6.4 & 6.4 & 6.4 & 6.4 & 6.4 \\
\hline Butanes, MBD (GE) & 86.2 & 163.4 & 167.5 & 184.2 & 198.2 & 207.0 & 185.0 \\
\hline $\begin{array}{l}\text { Methanol from natural gas, } \\
\text { MBD (GE) }\end{array}$ & 6.8 & & & & & & \\
\hline Ethanol, MBD (GE) & & 83.7 & 89.4 & 196.3 & 196.3 & 196.9 & 196.3 \\
\hline $\begin{array}{l}\text { Total non-petroleum, MBD } \\
\text { (GE) }\end{array}$ & 205.1 & 286.1 & 283.2 & 527.3 & 579.2 & 588.9 & 540.9 \\
\hline $\begin{array}{l}\text { Non-petroleum share, allocated } \\
\text { to gasoline, } \%\end{array}$ & 6.1 & 8.5 & 8.4 & 15.7 & 17.3 & 17.5 & 16.1 \\
\hline
\end{tabular}




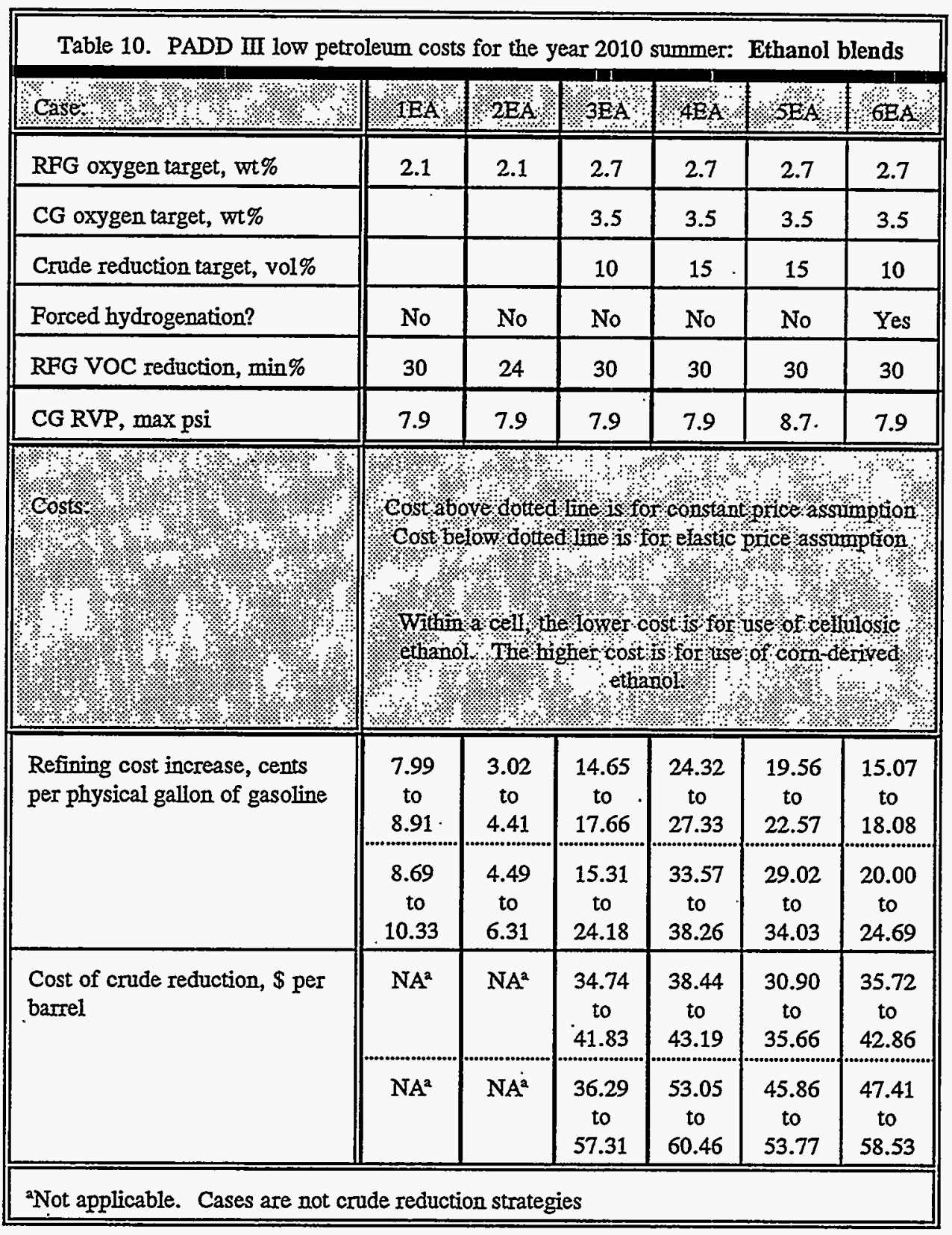




\begin{tabular}{|c|c|c|c|c|c|c|c|}
\hline Case & Base & EA & $2 \mathrm{EA}$ & SEA & $4 \mathrm{EA}$ & $5 \mathrm{EA}$ & 6EA \\
\hline RFG oxygen target, wt\% & & 2.1 & 2.1 & 2.7 & 2.7 & 2.7 & 2.7 \\
\hline CG oxygen target, wt\% & & . & & 3.5 & 3.5 & 3.5 & 3.5 \\
\hline $\begin{array}{l}\text { Crude reduction target, } \\
\text { vol\% }\end{array}$ & & & & 10 & 15 & 15 & 10 \\
\hline Forced hydrogenation? & & No & No & No & No & No & Yes \\
\hline $\begin{array}{l}\text { RFG VOC reduction, } \\
\text { min\% }\end{array}$ & & 30 & 30 & 30 & 30 & 30 & 30 \\
\hline CG RVP, max psi & & 7.9 & 7.9 & 7.9 & 7.9 & 8.7 & 7.9 \\
\hline $\begin{array}{l}\text { Hydrocrackate blended to: } \\
\text { distillates, } \mathrm{BBD}\end{array}$ & 28 & 160 & 124 & 266 & 553 & 530 & 365 \\
\hline
\end{tabular}




\subsection{Ethers}

Ethanol and methanol produced from non-petroleum feedstocks can be used to produce ethers by reacting the alcohols with tertiary olefins. Table 8 and Fig. 5 show that ethers can have octanes comparable to their parent alcohols, with low RVP and VOC blending values. MTBE, TAME, and ETBE are now limited to a maximum oxygen content of $2.7 \mathrm{wt}$ percent in gasoline. In the year 2010 low petroleum cases, the regulatory limit on oxygen is relaxed, and heavier ethers are allowed.

\subsubsection{Methyl Ethers}

Seven cases have been examined in which summer gasoline is oxygenated with ethers of methanol. The non-petroleum share is manipulated in these cases by increasing the oxygen content of gasolines, by decreasing the refinery input of crude oil, and by increasing the use of hydrogen. Two sensitivity cases illustrate the importance of assumptions about the availability of imported ethers. Tables 12 and 13 summarize case conditions, non-petroleum inputs, and refining costs. Key points related to these tables include:

The methanol and ether production base includes PADD III refineries and merchant plants.

Assumptions about the availability of imported ethers can have a large impact on refining costs. Except for two sensitivity cases, the maximum allowable volume of imported ethers is proportional to the total ether requirement. The proportionality factor is the ratio of foreign ether plant capacity to total ether plant capacity, existing and planned. When the ether source is restricted to PADD III production, the refining cost increase is almost doubled (compare cases $2 \mathrm{M}$ and $3 \mathrm{M}$ ). It is costly to produce olefins to satisfy the total ether requirement.

In case $6 \mathrm{M}$, ether imports are just enough to preclude investment in PADD III ether plants. With this high level of imported ethers, the refinery cost savings can be 5 to 8 cents per gallon of gasoline (compare cases $6 \mathrm{M}$ and $7 \mathrm{M}$ ). Appendix Table B-13 shows a large reduction in refinery investment for production and processing of $\mathrm{C} 4 \mathrm{~s}$ (naphtha cracking, C2-C5 dehydrogenation, and ether plant). The refinery costs savings could be overstated to the extent that foreign ether plant investment costs are not reflected in the MTBE price.

Based on the cost of crude oil reduction, the crude oil reduction strategy (case $4 \mathrm{M}$ ) is more attractive than hydrogenation (case $5 \mathrm{M}$ ) and oxygenation (case $6 \mathrm{M}$ ) strategies.

Crude oil reduction causes an increase in natural gas used as feed to the hydrogen plant (compare cases $2 \mathrm{M}$ and $4 \mathrm{M})$.

Forced hydrogenation causes an increase in natural gas used as feed to the hydrogen plant (compare cases $2 \mathrm{M}$ and $5 \mathrm{M}$ ).

The maximum non-petroleum share in Table 12 is 28 percent (case $7 \mathrm{M}$ ) at a refining cost increase of about 44 to 46 cents per gallon of gasoline. This maximum share is achieved with maximum oxygenation. It is possible that the non-petroleum share could be increased by hydrogenation. The hydrogenation possibilities are suggested by case $5 \mathrm{M}$ compared to $2 \mathrm{M}$, in which the non-petroleum share is increased by 1 percentage point, at a refining cost increase of about 8 cents per gallon of gasoline. 
In the maximum oxygenation cases, the EPA Complex Model is being used far beyond its valid limit of 3.7 wt percent oxygen. Beyond this limit, the Complex Model equations for methyl ethers have near-linear behavior, as shown in Figs. 6 and 7. The analysis of ethyl ethers will show that refining costs can be quite sensitive to assumptions about extrapolation of the Complex Model.

Gasoline blendstocks (Tables B-9 and B-10), gasoline properties (Tables B-11 and B-12), process capacity investments (Table B-13), and refinery fuel use changes (Table B-14) are shown in Appendix B. Key points related to these tables are:

In crude oil reduction (compare cases $2 \mathrm{M}$ and $4 \mathrm{M}$ ), increased natural gas feedstocks are used in expanded hydrogen plant capacity. The increased hydrogen stream is utilized in expanded hydrocracker capacity, with increased volumes of hydrocrackate blended to distillates, as shown in Table 14.

In forced hydrogenation (compare cases $2 \mathrm{M}$ and $5 \mathrm{M}$ ), increased natural gas feedstocks are used in expanded hydrogen plant capacity. The increased hydrogen stream is utilized in expanded hydrocracker capacity. There are increases in hydrocrackate blended to gasolines and to distillates (Table 14).

The reduction of crude oil results in increased utilization of molecule building processes such as polymerization and dimerization (compare cases $2 \mathrm{M}$ and $4 \mathrm{M}$ ).

With increased hydrogen production (compare cases $2 \mathrm{M}$ and $5 \mathrm{M}$ ), fractionation, and molecular conversions (compare cases $2 \mathrm{M}$ and $4 \mathrm{M}$ ), the refinery fuel use increases.

With the high oxygenation case $6 \mathrm{M}$ (with intermediate availability of imported ethers), there is substantial investment in ether plant, and in processes that produce olefins for etherification (e.g., FCC fractionation and C2-C5 dehydrogenation). Relative refinery fuel use is highest in this case.

In the high oxygenation cases ( $6 \mathrm{M}$ and $7 \mathrm{M}$ ), the very high percentage of MTBE (and other ethers of methanol) is related to:

The high RVP of RFG. In case 6M compared to 1M, MTBE (with blending RVP of 9 psi) has displaced a substantial volume of FCC naphthas (with RVP blending values near 7 psi).

The low sulfur/aromatics content of RFG. Contributors to sulfur/aromatics reduction include dilution with ethers and displacement of high sulfur/aromatics FCC stocks. Sulfur/aromatics reductions compensate for the VOC increase associated with the RVP increase of RFG.

The high NOx value of RFG. The high RFG olefins content, due to a high percentage of polymer gasolines, contributes to NOx. MTBE displacement of FCC naphthas depresses T50. The available olefin feeds can be either alkylated or polymerized. ORNLRYM selects polymer gasolines because they have higher T50s than alkylates. 
The low TAP value of RFG. MTBE dilution and replacement of FCC naphthas reduce sulfur and aromatics. MTBE dilution contributes to benzene reduction. Also, MTBE has a negative blending value for TAP.

Section 7 will compare the potential of methyl ether strategies with replacement of petroleum by other methods.

\begin{tabular}{|c|c|c|c|c|c|c|c|}
\hline \multicolumn{8}{|c|}{$\begin{array}{c}\text { Table 12. PADD III low petroleum components for the year } 2010 \text { summer: } \\
\text { oxygenates }\end{array}$} \\
\hline $\mathrm{Case} \cdot 4+4$ & Base & $\%$ & $2 \mathrm{M}$ & $3 M$ & $4 \mathrm{M}$ & \$ & $6 \mathrm{M}$ \\
\hline RFG oxygen target, wt\% & & 2.1 & 2.7 & 2.7 & 2.7 & 2.7 & 6.0 \\
\hline CG oxygen target, wt\% & & & 3.5 & 3.5 & 3.5 & 3.5 & 6.0 \\
\hline Crude reduction target, vol\% & & & 10 & 10 & 15 & 10 & 10 \\
\hline $\begin{array}{l}\text { Oxygenate imports allowed, } \\
\text { vol\% }\end{array}$ & & 43 & 43 & 0 & 43 & 43 & 43 \\
\hline Forced hydrogenation? & & No & No & No & No & Yes & No \\
\hline Conponents $-4.4 \%$ & \%.: & 1. & $\sqrt{4}$ & $1 \%$ & \%., & $\therefore 3$ & $\%$ \\
\hline Crude, MBD & 6135 & 5908 & 5521 & 5521 & 5215 & 5521 & 5521 \\
\hline Crude reduction, vol\% & & 3.7 & 10.0 & 10.0 & 15.0 & 10.0 & 10.0 \\
\hline $\begin{array}{l}\text { Hydrogen from natural gas, } \\
\text { MBD (GE) }\end{array}$ & 6.7 & 16.8 & 17.2 & 58.2 & 34.7 & 97.8 & 0 \\
\hline Natural gasoline, MBD (GE) & 96.1 & 96.1 & 96.1 & 96.1 & 96.1 & 96.1 & 96.1 \\
\hline Ethane, MBD (GE) & 2.8 & 2.8 & 2.8 & 2.8 & 2.8 & 2.8 & 2.8 \\
\hline Propane, MBD (GE) & 6.4 & 6.4 & 6.4 & 6.4 & 6.4 & 6.4 & 6.4 \\
\hline Butanes, MBD (GE) & 86.2 & 176.3 & 181.6 & 197.4 & 205.0 & 150.7 & 188.9 \\
\hline $\begin{array}{l}\text { Methanol from natural gas, } \\
\text { MBD (GE) }\end{array}$ & 6.8 & 41.1 & 54.8 & 96.0 & 54.8 & 54.8 & 113.1 \\
\hline MTBE imported, MBD (GE) & & & 199.5 & & 199.5 & 199.5 & 409.1 \\
\hline $\begin{array}{l}\text { Total non-petroleum, MBD } \\
\text { (GE) }\end{array}$ & 205.1 & 339.5 & 558.3 & 456.8 & 599.3 & 608.1 & 816.5 \\
\hline $\begin{array}{l}\text { Non-petroleum share, allocated } \\
\text { to gasoline, } \%\end{array}$ & 6.1 & 10.1 & 16.7 & 13.6 & 17.8 & 18.1 & 24.3 \\
\hline
\end{tabular}




\begin{tabular}{|c|c|}
\hline \multicolumn{2}{|c|}{$\begin{array}{l}\text { Table } 12 \text { (continued). PADD III low } \\
\text { petroleum components for the year } 2010 \\
\text { summer: Methyl ether oxygenates }\end{array}$} \\
\hline Case: : & $7 \mathrm{M}$ \\
\hline RFG oxygen target, wt\% & 6.0 \\
\hline CG oxygen target, wt\% & 6.0 \\
\hline $\begin{array}{l}\text { Crude reduction target, } \\
\text { vol\% }\end{array}$ & 10 \\
\hline $\begin{array}{l}\text { Oxygenate imports allowed, } \\
\text { vol\% }\end{array}$ & 71 \\
\hline Forced hydrogenation? & No \\
\hline Components & \\
\hline Crude, MBD & 5521 \\
\hline Crude reduction, vol\% & 10.0 \\
\hline $\begin{array}{l}\text { Hydrogen from natural gas, } \\
\text { MBD }(\mathrm{GE})^{\mathrm{a}}\end{array}$ & 0 \\
\hline $\begin{array}{l}\text { Natural gasoline, MBD } \\
\text { (GE) }\end{array}$ & \\
\hline Ethane, MBD (GE) & 2.8 \\
\hline Propane, MBD (GE) & 6.4 \\
\hline Butanes, MBD (GE) & 171.2 \\
\hline $\begin{array}{l}\text { Methanol from natural gas, } \\
\text { MBD (GE) }\end{array}$ & 54.2 \\
\hline $\begin{array}{l}\text { MTBE imported, MBD } \\
\text { (GE) }\end{array}$ & 694.7 \\
\hline $\begin{array}{l}\text { Total non-petroleum, MBD } \\
\text { (GE) }\end{array}$ & 929.3 \\
\hline $\begin{array}{l}\text { Non-petroleum share, } \\
\text { allocated to gasoline, \% }\end{array}$ & 27.7 \\
\hline GE/s gasolineet & \\
\hline
\end{tabular}


Table 13. PADD III low petroleum price elasticity variations for the year 2010 summer: Methyl ether oxygenates

\begin{tabular}{|c|c|c|c|c|c|c|c|}
\hline $\mathrm{case} \%$ & $1 \mathrm{M} \%$ & $2 \mathrm{M}$ & $3 \mathrm{M}$ & $4 \mathrm{~N}$ & S $\mathrm{NH}$ & $60 \mathrm{M}$ & $\% \mathrm{M}$ \\
\hline RPG oxygen target, wt\% & 2.1 & 2.7 & 2.7 & 2.7 & 2.7 & 6.0 & 6.0 \\
\hline CG oxygen target, wt\% & & 3.5 & 3.5 & 3.5 & 3.5 & 6.0 & 6.0 \\
\hline Crude reduction target, vol\% & & 10 & 10 & 15 & 10 & 10 & 10 \\
\hline $\begin{array}{l}\text { Oxygenate imports allowed, } \\
\text { vol\% }\end{array}$ & 43 & 43 & 0 & 43 & 43 & 43 & 71 \\
\hline Forced hydrogenation? & No & No & No & No & Yes & No & No \\
\hline (eosts & & stabov & ofted & $\begin{array}{l}3.5 \\
\text { for } \\
\text { for }\end{array}$ & $\begin{array}{l}\text { thstantp } \\
\text { tasticp p } \\
\end{array}$ & assumpt & : \\
\hline \multirow{2}{*}{$\begin{array}{l}\text { Refining cost increase, cents } \\
\text { per physical gallon of gasoline }\end{array}$} & 3.97 & 10.94 & 19.40 & 19.75 & 18.63 & 49.10 & 44.41 \\
\hline & 6.78 & 15.03 & 26.18 & 27.47 & 23.08 & 53.86 & 46.30 \\
\hline \multirow{2}{*}{$\begin{array}{l}\text { Cost of crude reduction, } \$ \text { per } \\
\text { barrel }\end{array}$} & $\mathrm{NA}^{\mathrm{a}}$ & 25.90 & 45.89 & 31.16 & 44.11 & 120.17 & 108.65 \\
\hline & $N A^{2}$ & 35.60 & 62.00 & 43.36 & 54.66 & 131.76 & 113.28 \\
\hline
\end{tabular}


Table 14. PADD III low petroleum effects on distillate blendstocks: Methyl ether oxygenated gasoline cases

\begin{tabular}{|c|c|c|c|c|c|c|c|}
\hline Case oो क & Base & $1 \mathrm{M}$ & $2 \mathrm{M}$ & $3 \mathrm{M}$ & $4 \mathrm{M}$ & $5 \mathrm{M}$ & $6 \mathrm{M}$ \\
\hline RFG oxygen target, wt\% & & 2.1 & 2.7 & 2.7 & 2.7 & 2.7 & 6.0 \\
\hline CG oxygen target, wt\% & & & 3.5 & 3.5 & 3.5 & 3.5 & 6.0 \\
\hline $\begin{array}{l}\text { Crude reduction target, } \\
\text { vol\% }\end{array}$ & & & 10 & 10 & 15 & 10 & 10 \\
\hline $\begin{array}{l}\text { Oxygenate imports } \\
\text { allowed, vol\% }\end{array}$ & & 43 & 43 & 0 & 43 & 43 & 43 \\
\hline Forced hydrogenation? & & No & No & No & No & Yes & No \\
\hline dudrocrackate blended to & 72 & 133 & 239 & 144 & 352 & 410 & 375 \\
\hline
\end{tabular}

\begin{tabular}{|c|c|}
\hline \multicolumn{2}{|c|}{$\begin{array}{c}\text { Table } 14 \text { (Continued). PADD III low petroleum effects on } \\
\text { distillate blendstocks: Methyl ether oxygenated gasoline } \\
\text { cases }\end{array}$} \\
\hline Case & ॥ै। $7 \mathrm{M}$ \\
\hline RFG oxygen target, wt\% & 6.0 \\
\hline CG oxygen target, wt\% & 6.0 \\
\hline $\begin{array}{l}\text { Crude reduction target, } \\
\text { vol\% }\end{array}$ & 10 \\
\hline $\begin{array}{l}\text { Oxygenate imports } \\
\text { allowed, vol\% }\end{array}$ & 71 \\
\hline Forced hydrogenation? & No \\
\hline $\begin{array}{l}\text { Hydroctackate blended to } \\
\text { distillates, MBD }\end{array}$ & । \\
\hline
\end{tabular}




\subsubsection{Ethyl Ethers}

Seven cases have been examined in which summer gasoline is oxygenated with ethers of ethanol. The low petroleum share is manipulated in these cases by increasing the oxygen content of gasolines, by decreasing the refinery input of crude oil, and by increasing the use of hydrogen. Tables 15 and 16 summarize case conditions, non-petroleum inputs, and refining costs. Key points related to these tables include:

A 54 cents per gallon credit has been applied to the ethanol component of ethyl ethers. Currently, such credit may not be available. For example, income tax credits cannot be claimed for ethers made from ethanol if the taxpayer is paying Alternate Minimum Tax.

Based on the cost of crude oil reduction, the crude oil reduction strategy (case 3E) is more attractive than hydrogenation (case $4 \mathrm{E}$ ) and oxygenation (cases $6 \mathrm{E}$ and $7 \mathrm{E}$ ) strategies.

Crude oil reduction (case 3E) and forced hydrogenation (case 4E) cause an increase in natural gas used as feed to the hydrogen plant (compared to case $2 \mathrm{E}$ ).

The maximum non-petroleum share in Table 15 is about 32 percent (case 7E) at a refining cost increase of about 41 to 55 cents per gallon of gasoline. This maximum share is achieved with maximum oxygenation and substantial crude reduction. It is possible that the non-petroleum share could be further increased by hydrogenation. The hydrogenation possibilities are suggested by comparing cases $4 \mathrm{E}$ and $2 \mathrm{E}$, in which the non-petroleum share is increased by 2 percentage points, at a cost increase of about 7 to 8 cents per gallon of gasoline.

Because of differences in raw material purchases and ether production, the ethyl ether cases (1E through $6 \mathrm{E}$ ) are not are not similar enough to allow a comparison of refinery cost increases with the methyl ether cases. Ethyl ether case $7 \mathrm{E}$ was defined for comparison with methyl ether case $6 \mathrm{M}$; these two cases have comparable hydrocarbon inputs. Tables 13 and 16 show that the refining cost increases for these two çases can be about the same: 49 to 54 cents per gallon for methyl ether case $6 \mathrm{M}$ and 47 to 55 cents per gallon for ethyl ether case $7 \mathrm{E}$, with corn-derived ethanol.

Case 7E also provides additional sensitivity on the crude reduction strategy. The cost of crude reduction is much less with 17 percent crude reduction (compare cases $5 \mathrm{E}$ and $7 \mathrm{E}$ ).

Refining costs are sensitive to assumptions about the use of corn-derived and cellulosic ethanol. In cases $5 \mathrm{E}, 6 \mathrm{E}$, and $7 \mathrm{E}$, the use of cellulosic ethanol can save 6 to 10 cents per gallon compared to the use of corn-derived ethanol.

Gasoline blendstocks (Tables B-15 and B-16), gasoline properties (Tables B-17 and B-18), process capacity investments (Table B-19), and refinery fuel use changes (Table B-20) are shown in Appendix B. Key points related to these tables are:

In crude oil reduction (compare cases $2 \mathrm{E}$ and $3 \mathrm{E}$; compare cases $5 \mathrm{E}$ and $7 \mathrm{E}$ ), increased natural gas feedstocks are used in expanded hydrogen plant capacity. The increased hydrogen stream is utilized in expanded hydrocracker capacity, with increased volumes of hydrocrackate blended to gasolines and distillates (Table 17). 
In forced hydrogenation (compare cases $2 \mathrm{E}$ and $4 \mathrm{E}$ ), increased natural gas feedstocks are used in expanded hydrogen plant capacity. The increased hydrogen stream is utilized in expanded hydrocracker capacity, with the highest volumes of hydrocrackate blended to gasoline. Increased volumes of hydrocrackate are also blended to distillates, as shown in Table 17.

The reduction of crude oil can result in increased utilization of molecule building processes such as polymerization or dimerization.

With increased hydrogen production, fractionation, and molecular conversions, the refinery fuel use increases.

In the high oxygenation cases, there is substantial investment in ether plant and light olefins production (C2-C5 dehydrogenation) for etherification. Relative refinery fuel use is highest in two of the high oxygenation cases (5E and 7E).

In high oxygenation cases $5 \mathrm{E}$ and $7 \mathrm{E}$, the very high percentages of ETBE (and other ethers of ethanol) are related to:

The low RVP of RFG. In cases 5E and 7E, ETBE (with blending RVP of 4 psi) has displaced a substantial volume of FCC naphthas (with RVP blending values near $7 \mathrm{psi}$ ).

High levels of acetaldehyde emissions. The valid upper limit for oxygen content in the EPA Complex Model is 3.7 wt percent. Fig. 8 shows that if the Complex Model is used beyond 3.7 wt percent oxygen, there is a greater-than-linear increase in acetaldehyde emissions. Given the high acetaldehyde emissions, the TAP constraint is achieved by very severe reductions in benzene, sulfur, and aromatics.

Contributors to sulfur reduction include dilution with ethers and displacement of high-sulfur FCC stocks.

Contributors to the aromatics and benzene reduction include dilution with ethers and displacement of high-aromatics reformate and FCC stocks.

The low olefins content of RFG. Contributors to the olefins reduction include dilution with ethers and displacement of high-olefins FCC stocks. Olefins reduction also contributes to TAP reduction.

The high utilization of the FCC feed hydrofiner. Hydrofined FCC feeds can have higher yields of olefins which can be used in ether production.

The low VOC value of RFG. Low RVP, low ETBE blending VOC value (Fig. 5), low sulfur and low aromatics contents contribute to the low VOC of RFG.

The low NOx value of RFG. Low sulfur, low olefins, and low aromatics contribute to the low NOx of RFG. 
If the acetaldehyde emissions equation were linear, then refining costs would be reduced by a substantial 11 to 12 cents per gallon of gasoline (compare cases 5E and $6 \mathrm{E}$ ). With the linear extrapolation, there are much-relaxed requirements for reduction of benzene, sulfur and aromatics. Emissions behavior is not known outside the range of the Complex Model, and vehicle testing is required to understand the costs and benefits of low petroleum gasoline with oxygen levels greater than 3.7 wt percent.

Section 7 will compare the potential of ethyl ether strategies with replacement of petroleum by other methods.

\begin{tabular}{|c|c|c|c|c|c|c|c|}
\hline cases $\mathrm{H}+\%$ & Base & \%1 & $2 \mathrm{E}$ & $3 \mathrm{BE}$ & $4 \mathrm{E}$ & SE & $6 \mathrm{E}$ \\
\hline RFG oxygen target, wt\% & & 2.1 & 2.7 & 2.7 & 2.7 & 6.0 & 6.0 \\
\hline CG oxygen target, wt\% & & & 3.5 & 3.5 & 3.5 & 6.0 & 6.0 \\
\hline Crude reduction target, vol\% & & & 10 & 15 & 10 & 10 & 10 \\
\hline Oxygenate imports allowed, vol\%? & & 43 & 43 & 43 & 43 & 43 & 43 \\
\hline Forced hydrogenation? & & No & No & No & Yes & No & No \\
\hline Linear acetaldehyde emissions? & & No & No & No & No & No & Yes \\
\hline componens & +\% & \$: & \%? & : & & ॥ै। & औß \\
\hline Crude, MBD & 6135 & 5979 & 5521 & 5215 & 5521 & 5521 & 5377 \\
\hline Crude reduction, vol\% & & 2.5 & 10.0 & 15.0 & 10.0 & 10.0 & 12.4 \\
\hline $\begin{array}{l}\text { Hydrogen from natural gas, MBD } \\
(\mathrm{GE})^{2}\end{array}$ & 6.7 & 36.7 & 40.3 & 54.7 & 167.2 & 77.7 & 2.7 \\
\hline Natural gasoline, MBD (GE) & 96.1 & 66.1 & 96.1 & 96.1 & 50.7 & 96.1 & 96.1 \\
\hline Ethane, MBD (GE) & 2.8 & 2.8 & 2.8 & 2.8 & 2.8 & 2.8 & 2.8 \\
\hline Propane, MBD (GE) & 6.4 & 6.4 & 6.4 & 6.4 & 6.4 & & \\
\hline Butanes, MBD (GE) & 86.2 & 165.6 & 169.5 & 189.4 & 150.7 & 153.4 & 151.2 \\
\hline $\begin{array}{l}\text { Methanol from natural gas, MBD } \\
\text { (GE) }\end{array}$ & 6.8 & & & & & & \\
\hline Ethanol, MBD (GE) & & 80.1 & 107.0 & 107.0 & 106.9 & 220.3 & 220.3 \\
\hline ETBE imported, MBD (GE) & & & 239.4 & 239.4 & 239.4 & 490.1 & 490.1 \\
\hline Total non-petroleum, MBD (GE) & 205.1 & 357.6 & 661.5 & 695.8 & 724.2 & 1040.4 & 963.1 \\
\hline $\begin{array}{l}\text { Non-petroleum share, allocated to } \\
\text { gasoline, } \%\end{array}$ & 6.1 & 10.6 & 19.6 & 20.7 & 21.5 & 31.0 & 28.6 \\
\hline
\end{tabular}




\begin{tabular}{|c|c|c|}
\hline \multicolumn{3}{|c|}{$\begin{array}{l}\text { Table } 15 \text { (Continued). PADD III low petroleum } \\
\text { components for the year } 2010 \text { summer: Ethyl ether } \\
\text { oxygenates }\end{array}$} \\
\hline Case & $\mathrm{Base}$ & HE \\
\hline RFG oxygen target, wt\% & & 6.0 \\
\hline CG oxygen target, wt\% & & 6.0 \\
\hline Crude reduction target, vol\% & & 17.0 \\
\hline Oxygenate imports allowed, vol\% & & 43 \\
\hline Forced hydrogenation? & & No \\
\hline Linear acetaldehyde emissions? & & No \\
\hline Components: & : & : \\
\hline Crude, MBD & 6135 & 5072 \\
\hline Crude reduction, vol\% & & 17.3 \\
\hline $\begin{array}{l}\text { Hydrogen from natural gas, MBD } \\
(\text { GE) }\end{array}$ & 6.7 & 81.0 \\
\hline Natural gasoline, MBD (GE) & 96.1 & 96.1 \\
\hline Ethane, MBD (GE) & 2.8 & 2.8 \\
\hline Propane, MBD (GE) & 6.4 & \\
\hline Butanes, MBD (GE) & 86.2 & 176.5 \\
\hline $\begin{array}{l}\text { Methanol from natural gas, MBD } \\
\text { (GE) }\end{array}$ & 6.8 & \\
\hline Ethanol, MBD (GE) & & 220.3 \\
\hline ETBE purchased, MBD (GE) & & 490.1 \\
\hline Total non-petroleum, MBD (GE) & 205.1 & 1066.7 \\
\hline $\begin{array}{l}\text { Non-petroleum share, allocated to } \\
\text { gasoline, } \%\end{array}$ & 6.1 & 31.8 \\
\hline${ }^{2} \mathrm{GE}$ is gasoline energy equivalent & & \\
\hline
\end{tabular}




\begin{tabular}{|c|c|c|c|c|c|c|c|}
\hline \multicolumn{8}{|c|}{$\begin{array}{l}\text { Table 16. PADD III low petroleum price elasticity variations for the year 2010: Ethyl ether } \\
\text { oxygenates }\end{array}$} \\
\hline rase- & \%I: & 28 & $3 \mathrm{~B}$ & 4 & SE & 68 & $7 \mathrm{p}$ \\
\hline RFG oxygen target, wt\% & 2.1 & 2.7 & 2.7 & 2.7 & 6.0 & 6.0 & 6.0 \\
\hline CG oxygen target, wt\% & & 3.5 & 3.5 & 3.5 & 6.0 & 6.0 & 6.0 \\
\hline Crude reduction target, vol\% & & 10 & 15 & 10 & 10 & 10 & 17 \\
\hline $\begin{array}{l}\text { Oxygenate imports allowed, } \\
\text { vol\% }\end{array}$ & 43 & 43 & 43 & 43 & 43 & 43 & 43 \\
\hline Forced hydrogenation? & No & No & No & Yes & No & No & No \\
\hline Linear acetaledhyde emissions? & No & No & No & No & No & Yes & No \\
\hline 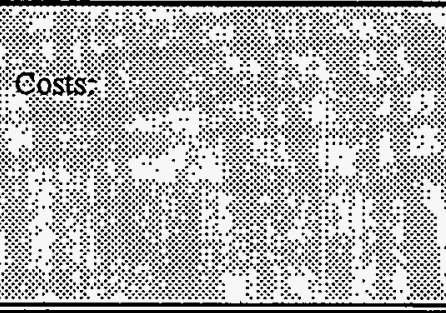 & & 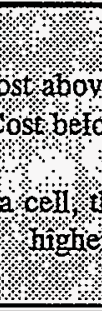 & 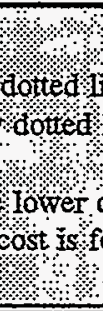 & $\begin{array}{l}\text { Hor } \\
\text { is for } \\
\text { stof for } \\
\text { ase of } \\
+4\end{array}$ & 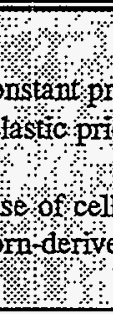 & $\begin{array}{l}\text { } \\
\text { assumin } \\
\text { assimp } \\
\text { osicetha } \\
\text { ethanol }\end{array}$ & 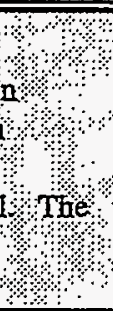 \\
\hline \multirow[t]{2}{*}{$\begin{array}{l}\text { Refining cost increase, cents } \\
\text { per physical gallon of gasoline }\end{array}$} & $\begin{array}{l}6.26 \\
\text { to } \\
7.50\end{array}$ & $\begin{array}{l}9.00 \\
\text { to } \\
11.81\end{array}$ & $\begin{array}{l}15.35 \\
\text { to } \\
18.16\end{array}$ & $\begin{array}{l}16.48 \\
\text { to } \\
19.29\end{array}$ & $\begin{array}{l}33.85 \\
\text { to } \\
39.39\end{array}$ & $\begin{array}{l}22.14 \\
\text { to } \\
27.67\end{array}$ & $\begin{array}{l}41.48 \\
\text { to } \\
47.02\end{array}$ \\
\hline & $\begin{array}{l}7.90 \\
\text { to } \\
9.50\end{array}$ & $\begin{array}{l}11.34 \\
\text { to } \\
15.71\end{array}$ & $\begin{array}{l}20.43 \\
\text { to } \\
25.39\end{array}$ & $\begin{array}{c}18.98 \\
\text { to } \\
23.34\end{array}$ & $\begin{array}{l}34.10 \\
\text { to } \\
44.18\end{array}$ & $\begin{array}{l}22.26 \\
\text { to } \\
32.44\end{array}$ & $\begin{array}{l}44.88 \\
\text { to } \\
55.13\end{array}$ \\
\hline \multirow[t]{2}{*}{$\begin{array}{l}\text { Cost of crude reduction, } \$ \text { per } \\
\text { barrel }\end{array}$} & $N A^{2}$ & $\begin{array}{l}21.35 \\
\text { to } \\
28.01\end{array}$ & $\begin{array}{l}24.28 \\
\text { to } \\
28.72\end{array}$ & $\begin{array}{l}39.08 \\
\text { to } \\
45.75\end{array}$ & $\begin{array}{l}82.68 \\
\text { to } \\
96.20\end{array}$ & $\begin{array}{l}43.76 \\
\text { to } \\
54.68\end{array}$ & $\begin{array}{c}58.48 \\
\text { to } \\
66.30\end{array}$ \\
\hline & $N A^{\mathrm{a}}$ & $\begin{array}{l}26.89 \\
\text { to } \\
37.26\end{array}$ & $\begin{array}{l}32.32 \\
\text { to } \\
40.15\end{array}$ & $\begin{array}{l}45.00 \\
\text { to } \\
55.36\end{array}$ & $\begin{array}{c}83.27 \\
\text { to } \\
107.90\end{array}$ & $\begin{array}{l}44.00 \\
\text { to } \\
64.11\end{array}$ & $\begin{array}{c}63.28 \\
\text { to } \\
77.74\end{array}$ \\
\hline
\end{tabular}


Table 17. PADD III low petroleum effects on distillate blendstocks: Ethyl ether oxygenated gasoline cases

\begin{tabular}{|c|c|c|c|c|c|c|c|}
\hline Case $\quad$ ol $\quad$ । & Base & $\mathrm{HE}$ & $2 \mathrm{E}$ & $3 \mathrm{E}$ & $4 \mathrm{E}$ & $5 \mathrm{E}$ & $6 \mathrm{E}$ \\
\hline RFG oxygen target, wt\% & & 2.1 & 2.7 & 2.7 & 2.7 & 6.0 & 6.0 \\
\hline CG oxygen target, wt\% & & & 3.5 & 3.5 & 3.5 & 6.0 & 6.0 \\
\hline Crude reduction target, vol\% & & & 10 & 15 & 10 & 10 & 10 \\
\hline $\begin{array}{l}\text { Oxygenate imports allowed, } \\
\text { vol\% }\end{array}$ & & 43 & 43 & 43 & 43 & 43 & 43 \\
\hline Forced hydrogenation? & & No & No & No & Yes & No & No \\
\hline Linear acetaldehyde emissions? & & No & No & No & No & No & Yes \\
\hline Hydrocrackate blended to & 72 & 76 & 66 & 186 & 172 & 182 & 307 \\
\hline
\end{tabular}

\begin{tabular}{|c|c|c|}
\hline \multicolumn{3}{|c|}{$\begin{array}{l}\text { Table } 17 \text { (Continued). PADD III low petroleum } \\
\text { effects on distillate blendstocks: Ethyl ether } \\
\text { oxygenated gasoline cases }\end{array}$} \\
\hline case & Basey: & $\pi$ \\
\hline RFG oxygen target, wt\% & & 6.0 \\
\hline CG oxygen target, wt\% & & 6.0 \\
\hline Crude reduction target, vol\% & & 17 \\
\hline $\begin{array}{l}\text { Oxygenate imports allowed, } \\
\text { vol\% }\end{array}$ & & 43 \\
\hline Forced hydrogenation? & & No \\
\hline Linear acetaldehyde emissions? & & No \\
\hline $\begin{array}{l}\text { Hydrocrackate blended to } \\
\text { distallates } \mathrm{MBBD}\end{array}$ & 72 & 198 \\
\hline
\end{tabular}




\subsection{Vegetable Oil}

Vegetable oils have been used with mixed success as diesel engine fuels. In short term testing in direct injection engines, neat vegetable oils have performed very closely to diesel fuel oil. However, long term testing of vegetable oils in direct injection engines has usually resulted in engine damage or engine failure, caused by fuel filter plugging, carbon buildup in the injection chamber and injector coking. The poor performance of vegetable oils could be explained by the fact that vegetable oils are more unsaturated than diesel fuel oils and polymerize inside the combustion chamber more readily. The high viscosities of vegetable oils could also be a reason for poor performance. Methods tested to solve engine performance problems have included blending vegetable oils with diesel fuels; fumigating vegetable oils with propane and microemulsifying the oils with solvents such as alcohol; and esterification. ${ }^{42}$

Laboratory tests have suggested that vegetable oils, such as rapeseed oil, can be converted to a mixture of liquid and gaseous hydrocarbons, with high conversions, in fixed bed catalytic reactors. ${ }^{43,44}$ The possibilities for using rapeseed oil as part of the feedstock for the fluid catalytic cracking process have also been investigated..$^{45}$ In these catalytic processes, rapeseed oil is converted to hydrocarbons, water, and oxides of carbon. The hydrocarbon products appear to be suitable for blending to gasoline and distillates.

Several cases have been examined for the production of summer gasoline in which rapeseed oil is used to increase the non-petroleum share. In these cases, it is assumed that by the year 2010, FCC technology can accommodate up to 5 wt percent rapeseed oil in FCC feed. For accounting purposes, it is assumed that each barrel of rapeseed oil feed can be converted into 0.9 barrels of non-petroleum blendstocks. for gasoline. The yield assumptions are based on product spectra for fixed bed catalytic conversion of pure vegetable oils..$^{43,44,46}$

The published properties for rapeseed-associated naphtha are based on experimental results reported without reference to a control experiment. ${ }^{45}$ The published properties (with inferences about suifur and aromatics contents) have significant improvements in emissions values ("High quality"), versus typical petroleum-derived FCC naphthas. Additional investigations are required to confirm and explain these property improvements. Given the uncertainty about property values, a sensitivity case is examined in which rapeseed-associated naphtha is assumed to have properties of petroleum-derived naphthas ("Low quality"). Naphtha properties are shown in Table 18. 


\begin{tabular}{||l||c|c||}
\hline \multicolumn{2}{|c|}{ Range of blending properties of rapeseed-associated FCC naphthas } \\
\hline \multicolumn{1}{|c||}{ Low quality } & High quality \\
\hline \hline Research Octane Number & 90.8 & 94.1 \\
\hline Motor Octane Number & 78.8 & 80.6 \\
\hline RVP, psi & 6.9 & 3.2 \\
\hline Aromatics, vol\% & 29.0 & 40.0 \\
\hline Benzene, vol\% & 1.1 & 0.7 \\
\hline Olefins, vol\% & 29.0 & 25 \\
\hline Sulfur, ppm & 285 & 235 \\
\hline E200, \% & 28 & 23 \\
\hline E300, \% & 76 & 79 \\
\hline Specific gravity & .7507 & .7699 \\
\hline Summer TAP, mg/mi & 70 \\
\hline NOx, mg/mi & 70 & 1470 \\
\hline VOC, mg/mi & 1510 & 790 \\
\hline \hline a'Emissions blending values can vary with case & \\
\hline \hline
\end{tabular}

The rapeseed oil cases are variations of a methyl ether case with moderate crude reduction (2M) and oxygenation; and an ethyl ether case with moderate crude reduction and high oxygenation (5E). Tables 19 and 20 summarize case conditions, non-petroleum inputs, and refining costs. Gasoline blendstocks (Tables B-21 and B-22), gasoline properties (Tables B-23 and B-24), process capacity investments (Table B-25), and refinery fuel use changes (Table B-26) are shown in Appendix B. Key points related to these tables include:

In the rapeseed oil cases, the non-petroleum share of gasoline is increased.

The use of rapeseed oil causes an increase in refining costs.

For case $1 \mathrm{R}$ compared to case $2 \mathrm{M}, 85$ percent of the cost increase is due to the high purchase price of rapeseed oil (estimated to be nearly $\$ 70$ per barrel $^{42,47}$ ).

For case 1RX compared to case $2 \mathrm{M}$, the cost of rapeseed oil has been offset by investment and operations cost savings due to the high quality naphtha. In case $1 \mathrm{RX}$, there are reduced costs for meeting specifications for octane, benzene, NOx and VOC. In cases $1 \mathrm{R}$ and $1 \mathrm{RX}$, the yield of rapeseed-associated naphtha is ten times the input of rapeseed oil, and 25 percent of gasoline is 
rapeseed-associated naphtha. Because of its high percentage in gasoline, rapeseed-associated naphtha can have substantial quality and cost impacts.

For case $2 \mathrm{RX}$ compared to case $2 \mathrm{E}$, less than 20 percent of the cost increase is due to the high purchase price of rapeseed oil. Most of the cost increase is related to the cost of maintaining gasoline's minimum RVP of $6.5 \mathrm{psi}$. With a rapeseed-associated naphtha yield ten times the input of rapeseed oil, nearly 8 percent of gasoline is rapeseed-associated naphtha (RVP blending value of 3.2 psi). Gasoline contains 38 percent ethyl ethers (RVPs of 4 psi or less). The remaining gasoline components must have an average RVP of at least 11.3 psi. The availability of high-RVP butanes is limited because of the demands for ether production.

In case $2 \mathrm{RX}$ compared to case $2 \mathrm{E}$, increased natural gas feedstocks are used in expanded hydrogen plant capacity. The increased hydrogen stream is used in expanded naphtha and gas oil hydrocracking capacity. Increased hydrocracking provides increased volumes of $\mathrm{C} 4 \mathrm{~s}$ for direct blending to gasoline and for production of a greater volume of C4-based ether (with higher RVP than C5/C6-based ethers). Additionally, a higher volume of light hydrocrackate is blended to gasoline. These activities are driven by the minimum RVP specification.

Refining costs are sensitive to assumptions about the use of corn-derived and cellulosic ethanol. In cases $5 \mathrm{E}$ and $2 \mathrm{RX}$, the use of cellulosic ethanol can save 6 to 10 cents per gallon compared to the use of corn-derived ethanol.

To increase confidence in the potential for rapeseed oil, more research will have to be reported on process reliability and naphtha quality in FCC rapeseed oil service. 


\begin{tabular}{|c|c|c|c|c|c|c|}
\hline Case & Base & $2 M$ & 姃 & $1 R \times$ & $5 \mathrm{E}$ & $2 R X$ \\
\hline RFG oxygen target, wt\% & & 2.7 & 2.7 & 2.7 & 6.0 & 6.0 \\
\hline CG oxygen target, wt $\%$ & & 3.5 & 3.5 & 3.5 & 6.0 & 6.0 \\
\hline $\begin{array}{l}\text { Ether type } \\
(M=\text { methyl; } E=\text { ethyl })\end{array}$ & & $\mathbf{M}$ & $\mathbf{M}$ & M & $\mathbf{E}$ & $\mathbf{E}$ \\
\hline Crude reduction target, vol\% & & 10 & 10 & 10 & 10 & 10 \\
\hline Oxygenate imports allowed, vol\% & & 43 & 43 & 43 & 43 & 43 \\
\hline Forced hydrogenation? & & No & No & No & No & No \\
\hline Rapeseed oil feed? & & No & Yes & Yes & No & Yes \\
\hline $\begin{array}{l}\text { FCC naphtha (rapeseed associated) } \\
\text { quality }\end{array}$ & & NA & Low & High & NA & High \\
\hline Components $\therefore$ & & & & & : & \\
\hline Crude, MBD & 6135 & 5521 & 5521 & 5521 & 5521 & 5521 \\
\hline Crude reduction, vol\% & & 10.0 & 10.0 & 10.0 & 10.0 & 10.0 \\
\hline $\begin{array}{l}\text { Hydrogen from natural gas, MBD } \\
\text { (GE) }^{2}\end{array}$ & 6.7 & 17.2 & 10.7 & 19.0 & 77.7 & 104.2 \\
\hline Natural gasoline, MBD (GE) & 96.1 & 96.1 & 96.1 & 96.1 & 96.1 & 96.1 \\
\hline Ethane, MBD (GE) & 2.8 & 2.8 & 2.8 & 2.8 & 2.8 & 2.8 \\
\hline Propane, MBD (GE) & 6.4 & 6.4 & 6.4 & 6.4 & & \\
\hline Butanes, MBD (GE) & 86.2 & 181.6 & 179.0 & 175.2 & 153.4 & 154.2 \\
\hline Methanol from natural gas, MBD (GE) & 6.8 & 54.8 & 54.8 & 54.6 & & \\
\hline MTBE imports, MBD (GE) & & 199.5 & 199.5 & 199.5 & & \\
\hline Ethanol, MBD (GE) & & & & & 220.3 & 221.1 \\
\hline ETBE imports, MBD (GE) & & & & & 490.1 & 490.1 \\
\hline Rapeseed oil, MBD (GE) & & & 84.3 & 84.3 & & 26.4 \\
\hline Total non-petroleum, MBD (GE) & 205.1 & 558.3 & 633.6 & 637.8 & 1040.4 & 1094.9 \\
\hline $\begin{array}{l}\text { Non-petroleum share, allocated to } \\
\text { gasoline, } \%\end{array}$ & 6.1 & 16.7 & 18.9 & 19.0 & 31.0 & 32.6 \\
\hline
\end{tabular}


Table 20. PADD III low petroleum price elasticity variations for the year 2010 summer: Rapeseed oil feedstock

\begin{tabular}{|c|c|c|c|c|c|c|}
\hline $\mathrm{cose}, 4 \%$ & Base & $2 M$ & \% & $12 X$ & $35 \mathrm{~B}$ & $2 R X$ \\
\hline RFG oxygen target, wt\% & & 2.7 & 2.7 & 2.7 & 6.0 & 6.0 \\
\hline CG oxygen target, wt\% & & 3.5 & 3.5 & 3.5 & 6.0 & 6.0 \\
\hline $\begin{array}{l}\text { Ether type } \\
(M=\text { methyl; } E=\text { ethyl) }\end{array}$ & & $M$ & $\mathbf{M}$ & $M$ & $E$ & $\mathbf{E}$ \\
\hline Crude reduction target, vol\% & & 10 & 10 & 10 & 10 & 10 \\
\hline Oxygenate imports allowed, vol\% & & 43 & 43 & 43 & 43 & 43 \\
\hline Forced hydrogenation? & & No & No & No & No & No \\
\hline Rapeseed oil feed? & & No & Yes & Yes & No & Yes \\
\hline $\begin{array}{l}\text { FCC naphtha (rapeseed associated) } \\
\text { quality }\end{array}$ & & NA & Low & High & NA & High \\
\hline 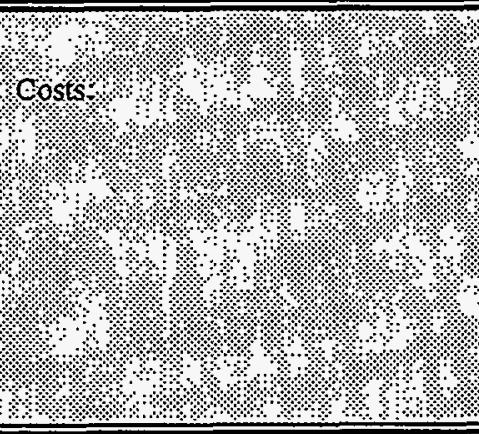 & \multicolumn{6}{|c|}{ 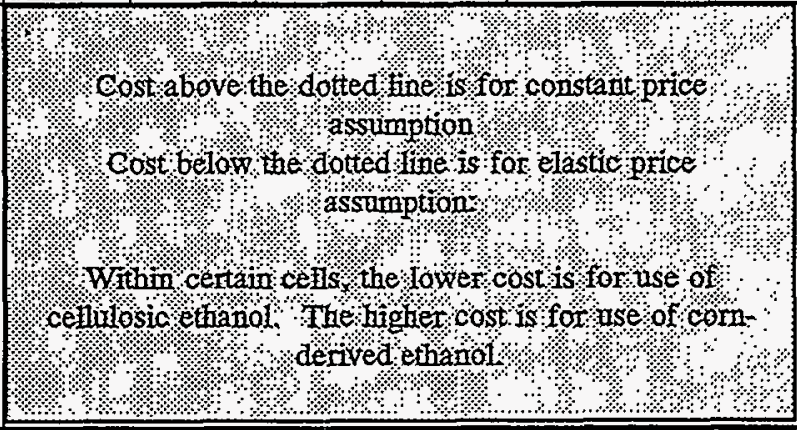 } \\
\hline \multirow[t]{2}{*}{$\begin{array}{l}\text { Refining cost increase, cents per } \\
\text { physical gallon of gasoline }\end{array}$} & & 10.94 & 14.81 & 11.98 & $\begin{array}{c}33.85 \\
\text { to } \\
39.39\end{array}$ & $\begin{array}{c}38.83 \\
\text { to } \\
44.37\end{array}$ \\
\hline & & 15.03 & 18.36 & 15.05 & $\begin{array}{c}34.10 \\
\text { to } \\
44.18\end{array}$ & $\begin{array}{c}38.98 \\
\text { to } \\
49.10\end{array}$ \\
\hline \multirow[t]{2}{*}{$\begin{array}{l}\text { Cost of crude reduction, } \$ \text { per } \\
\text { barrel }\end{array}$} & & 25.90 & 35.06 & 28.37 & $\begin{array}{c}82.68 \\
\text { to } \\
96.20\end{array}$ & $\begin{array}{c}95.05 \\
\text { to } \\
108.61\end{array}$ \\
\hline & & 35.60 & 43.49 & 35.64 & $\begin{array}{c}83.27 \\
\text { to } \\
107.90\end{array}$ & $\begin{array}{c}95.41 \\
\text { to } \\
120.19\end{array}$ \\
\hline
\end{tabular}


Table 21. PADD III low petroleum effects on distillate blendstocks:

- Rapeseed oil feedstock

\begin{tabular}{|c|c|c|c|c|c|c|}
\hline Case & Base: & $2 \mathrm{M}$ & 1R: & IRX & $5 \mathrm{E}$ & $2 R X$ \\
\hline RFG oxygen target, wt\% & & 2.7 & 2.7 & 2.7 & 6.0 & 6.0 \\
\hline CG oxygen target, wt\% & & 3.5 & 3.5 & 3.5 & 6.0 & 6.0 \\
\hline Ether type & & M & M & M & $\mathrm{E}$ & $\mathrm{E}$ \\
\hline $\begin{array}{l}\text { Crude reduction target, } \\
\text { vol\% }\end{array}$ & & 10 & 10 & 10 & 10 & 10 \\
\hline $\begin{array}{l}\text { Oxygenate imports } \\
\text { allowed, vol\% }\end{array}$ & & 43 & 43 & 43 & 43 & 43 \\
\hline Forced hydrogenation? & & No & No & No & No & No \\
\hline Rapeseed oil feed? & & No & Yes & Yes & No & Yes \\
\hline $\begin{array}{l}\text { FCC naphtha (rapeseed } \\
\text { associated) quality }\end{array}$ & & NA & Low & High & NA & High \\
\hline $\begin{array}{l}\text { Hydrocrackate blended to } \\
\text { distiflates } \mathrm{MBDD}\end{array}$ & 72 & 239 & 160 & 133 & 182 & 264 \\
\hline
\end{tabular}




\section{COMPARISON OF LOW PETROLEUM SUMMER GASOLINE OPTIONS}

Fig. 9 shows the relationship between refining cost increase and non-petroleum share for all summer low petroleum cases. For a given non-petroleum share, costs are generally higher for cornderived ethanol blends, intermediate for cellulosic ethanol and methyl ether blends, and lower for ethyl ether blends. Non-petroleum shares are limited to about 20 percent for ethanol blends. For ethers, the maximum shares are above 30 percent. The maximum non-petroleum share among all cases is 33 percent for high oxygenation with ethyl ethers in combination with high-quality rapeseed-associated naphtha (case $2 \mathrm{RX}$ ). The refining cost increase for this maximum share case is 39 to 49 cents per gallon of gasoline. The lower cost increase is for use of cellulosic ethanol, and the higher cost increase is for use of cornderived ethanol with elastic prices.

The cases are ordered according to refining cost increase in Fig. 10. For reference, case descriptions are summarized in the Supplement to Figures, which follows Fig. 10. Increasing cost is almost in the same order as increasing oxygen content. Within a given oxygenation group, refining costs are higher for forced hydrogenation and forced crude reduction. For a case using ethanol, the cost increase can vary greatly, depending upon whether corn-derived or cellulosic ethanol is used.

Refining cost and non-petroleum share have a significant correlation. The cases are ordered according to non-petroleum share in Fig. 11. Increasing share is in the same order as increasing oxygen content. Within a given oxygenation group, the non-petroleum share is higher for forced hydrogenation and forced crude reduction.

Fig. 12 shows the relationship between the cost to reduce crude oil use and the non-petroleum share. For a given non-petroleum share, costs are generally higher for corn-derived ethanol blends, intermediate for cellulosic ethanol and methyl ether blends, and lower for ethyl ether blends. For the maximum non-petroleum share case ( $2 \mathrm{RX}$ ), the cost to reduce crude oil use is $\$ 95$ to $\$ 120$ per barrel. The lower cost is for use of cellulosic ethanol, and the higher cost increase is for use of corn-derived ethanol with elastic prices.

In Fig. 13, the cases are ordered according to increasing cost to reduce crude oil use. Increasing cost is almost in the same order as increasing oxygen content. Within a given oxygenation group, the cost to reduce crude oil tends to be lower for forced crude reduction. For a case using ethanol, the cost to reduce crude oil use can vary greatly, depending upon whether corn-derived or cellulosic ethanol is used.

Fig. 14 shows the relationship between crude oil use reduction and the non-petroleum share. The maximum reduction of about 17 percent is associated with a non-petroleum share of about 32 percent (case $7 \mathrm{E}$ with high oxygenation with ethyl ethers). In Fig. 15, the cases are ordered according to increasing crude oil use reduction. Except for one case, crude oil reduction is a minimum constraint (the exception is for the high oxygenation case $6 \mathrm{E}$, using an alternate form of the Complex Model).

Fig. 16 shows the relationship between refinery fuel use and the non-petroleum share for summer low petroleum cases. For a given non-petroleum share, refinery fuel use is generally higher for ethanol blends, intermediate for methyl ether blends, and lower for ethyl ether blends. The maximum refinery fuel use among all cases is about 12 percent for intermediate oxygenation with ethanol in combination with forced crude reduction (case 5EA). 
The cases are ordered according to refinery fuel use increase in Fig. 17. With several exceptions, refinery fuel use is higher for forced hydrogenation and forced crude reduction. Given the hydrogenation and crude reduction effect, refinery fuel use tends to be lower with higher levels of oxygenation (i.e., with greater purchase of imported ethers).

Table 22 uses the maximum crude reduction case (7E) and the maximum non-petroleum share case (2RX) to illustrate material flow adjustments to a reduction in crude oil. In case $7 \mathrm{E}$, crude oil reduction is balanced by increases in non-petroleum inputs, natural gas for fuel (not credited as a nonpetroleum input), and a product output decrease (coke). In case $2 \mathrm{RX}$, crude oil reduction is balanced by increases in non-petroleum inputs and a product output decrease (coke). In both cases, there is a substantial increase in refinery fuel relative to the Base case.

Fig. 18 shows the relationship between refinery investment and the non-petroleum share for all low petroleum cases. For a given non-petroleum share, there is a tendency toward higher investment for ethanol blends, intermediate for methyl ether blends, and lower for ethyl ether blends. The maximum refinery investment is for the maximum crude reduction case (7E).

The cases are ordered according to refinery investment in Fig. 19. Increasing investment tends to be in the same order as increasing oxygen content. Within a given oxygenation group, investment costs tend to be higher for forced hydrogenation and forced crude reduction.

Results suggest that it is technically possible, but expensive, to achieve the 30 percent replacement fuel target in summer gasolines. The lowest cost case $(6 \mathrm{E}$, high oxygenation with ethyl ethers, using an alternate form of the Complex Model) achieves a near-30 percent non-petroleum share at a refining cost increase of 22 to 32 cents per gallon of gasoline. In case $6 \mathrm{E}$, the cost to reduce crude oil use is $\$ 44$ to $\$ 64$ per barrel. The lower costs are for use of cellulosic ethanol, and the higher costs are for use of corn-derived ethanol with elastic prices. 


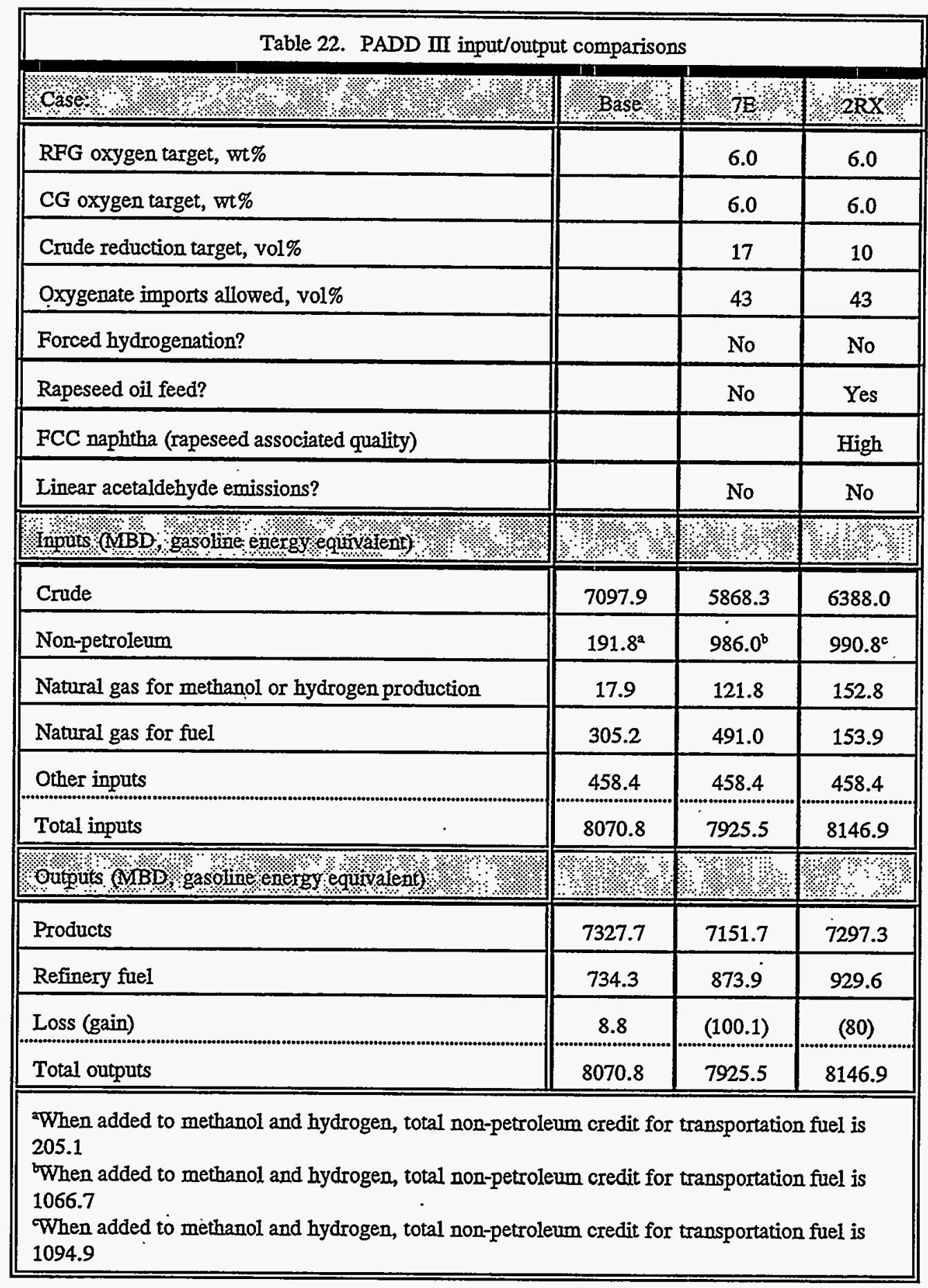




\section{PRODUCTION OF LOW PETROLEUM WINTER GASOLINE}

Compared with summer gasolines, emissions constraints are less stringent for winter gasolines, and production costs are lower. There is no VOC reduction requirement, and RVP is limited primarily by concern for sufficient volatility in low temperature start-ups. NOx emissions are not allowed to increase relative to the winter statutory baseline gasoline. Winter TAP emissions are to be averaged with summer TAP emissions to achieve a 20 percent annual TAP reduction relative to baseline gasolines.

Three cases have been examined for high levels of oxygenation in winter gasoline. The oxygenates are ethanol, methyl ethers, and ethyl ethers. A minimum crude oil reduction of 10 percent is required, and imports of oxygenates are just enough to preclude investment in PADD III ether plants. Tables 23 and 24 summarize case conditions, non-petroleum inputs, and refining cost increases. Key points related to these tables include:

Non-petroleum shares at or above 30 percent are achieved with high oxygenation with ethers (cases MW and EW).

The maximum non-petroleum share is 37 percent, for high oxygenation with ethyl ethers (case $\mathrm{EW}$ ).

Oxygenation with ethanol is associated with a relatively low refining cost increase (case EAW), but the non-petroleum share is only 22 percent because of ethanol's high oxygen content. Compared with ethers, a smaller volume of ethanol is required to achieve a given oxygen content in gasoline.

Refining costs are sensitive to assumptions about the use of corn-derived and cellulosic ethanol. In case EW, the use of cellulosic ethanol can save 6 to 14 cents per gallon compared to the use of corn-derived ethanol.

Ethanol winter case EAW does not have a summer counterpart case. In the summer, high oxygenation with ethanol cannot be achieved because of the VOC constraint. Nevertheless, the refining cost increase for high oxygenation in winter case EAW is at least 20 percent lower than the increase for intermediate oxygenation with corn-derived ethanol in summer cases 3EA through 6EA in Table 10. With cellulosic ethanol, the refining cost increase for winter case EAW is at least 67 percent lower than the increase for summer cases 3EA through 6EA.

The premises for methyl ether winter case MW are comparable to summer case $7 \mathrm{M}$ (Table 13). The refining cost increase and the cost of crude reduction for the winter case are at least 37 percent lower than the summer case.

Gasoline blendstocks (Tables D-1, D-3, and D-4), gasoline properties (Tables D-2, D-5, and D6), process capacity investment (Table D-7), and refinery fuel use (Table D-8) are shown in Appendix D. Key points related to these tables are:

Winter TAP is not a binding constraint in any case. Therefore, the summer TAP constraint could be relaxed, with refining cost savings, for several ethyl ether cases $(5 \mathrm{E}, 6 \mathrm{E}, 7 \mathrm{E}$, and $2 \mathrm{RX}$, as shown in Tables B-17 and B-23). 
The cost increase for ethanol case EA is due largely to fuel economy costs and control of distillation properties.

Contributors to the cost increase for ether cases $\mathrm{MW}$ and $\mathrm{EW}$ include fuel economy costs and control of distillation properties and satisfying a minimum RVP.

Methyl ether production costs are higher than ethyl ether production costs. The assumption for ether imports requires full utilization of refinery ether plant capacity in cases $\mathrm{MW}$ and $\mathrm{EW}$.

In methyl ether case MW, C4s are needed to build blendstocks (e.g., heavier alkylate and polymer gasoline) for control of distillation properties. Therefore $\mathrm{C} 4$ availability is reduced, and cost is increased for production of ethers.

The ethyl ether case EW requires less distillation correction, and $\mathrm{C} 4$ availability is greater and cost is lower for ether production. 


\begin{tabular}{|c|c|c|c|c|}
\hline$\because$ & ABase & $\mathrm{BAW}$ & \%W & EW \\
\hline RFG oxygen target, wt\% & & 6.0 & 6.0 & 6.0 \\
\hline CG oxygen target, wt\% & & 6.0 & 6.0 & 6.0 \\
\hline Oxygenate type & & Ethanol & Methyl ethers & Ethyl ethers \\
\hline $\begin{array}{l}\text { Crude reduction target, } \\
\text { vol\% }\end{array}$ & & 10 & 10 & 10 \\
\hline $\begin{array}{l}\text { Oxygenate imports allowed, } \\
\text { vol\% }\end{array}$ & & 100 & 66 & 70 \\
\hline \multicolumn{5}{|l|}{ Components: } \\
\hline Crude, MBD & 5763 & 5187 & 5187 & 5015 \\
\hline Crude reduction, vol\% & & 10.0 & 10.0 & 13.0 \\
\hline $\begin{array}{l}\text { Hydrogen from natural gas, } \\
\text { MBD (GE) }\end{array}$ & 5.8 & & & 15.4 \\
\hline $\begin{array}{l}\text { Natural gasoline, MBD } \\
\text { (GE) }\end{array}$ & 90.9 & 90.9 & 65.4 & 90.9 \\
\hline Ethane, MBD (GE) & 3.4 & 3.4 & 3.4 & \\
\hline Propane, MBD (GE) & 5.1 & 5.1 & 5.1 & \\
\hline Butanes, MBD (GE) & 174.2 & 186.4 & 174.2 & 159.7 \\
\hline $\begin{array}{l}\text { Methanol from natural gas, } \\
\text { MBD (GE) }\end{array}$ & & r & 56.3 & \\
\hline MTBE imports, MBD (GE) & & & 568.2 & \\
\hline Ethanol, MBD (GE) & & 355 & & 100.7 \\
\hline ETBE imports, MBD (GE) & & & & 708.0 \\
\hline $\begin{array}{l}\text { Total non-petroleum, MBD } \\
\text { (GE) }\end{array}$ & 279.5 & 640.5 & 871.6 & 1074.7 \\
\hline $\begin{array}{l}\text { Non-petroleum share, } \\
\text { allocated to gasoline, \% }\end{array}$ & 9.5 & 21.7 & 29.6 & 36.5 \\
\hline
\end{tabular}




\begin{tabular}{|c|c|c|c|}
\hline \multicolumn{4}{|c|}{$\begin{array}{c}\text { Table 24. PADD III low petroleum price elasticity variations for the year } 2010 \\
\text { winter }\end{array}$} \\
\hline 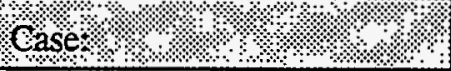 & EAW & $1 \mathrm{WW}$ & $\mathrm{EW}$ \\
\hline RFG oxygen target, wt\% & 6.0 & 6.0 & 6.0 \\
\hline CG oxygen target, wt\% & 6.0 & 6.0 & 6.0 \\
\hline Oxygenate type & Ethanol & Methyl ethers & Ethyl ethers \\
\hline $\begin{array}{l}\text { Crude reduction target, } \\
\text { vol\% }\end{array}$ & 10 & 10 & 10 \\
\hline $\begin{array}{l}\text { Oxygenate imports allowed, } \\
\text { vol\% }\end{array}$ & 100 & 66 & 70 \\
\hline 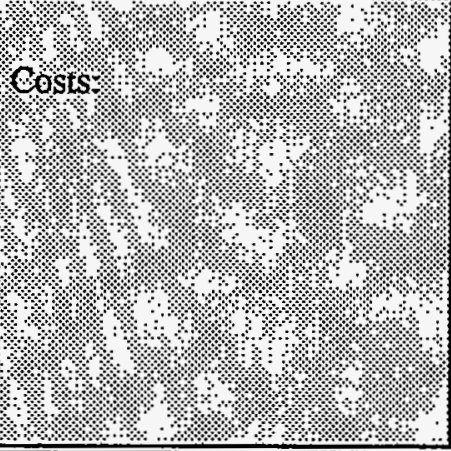 & 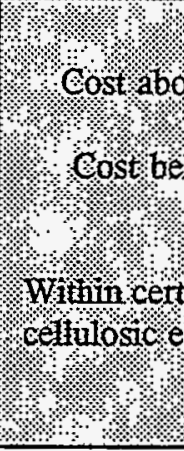 & 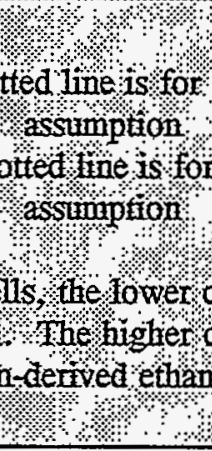 & 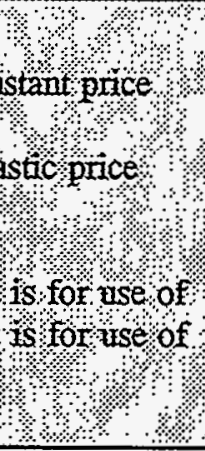 \\
\hline \multirow[t]{2}{*}{$\begin{array}{l}\text { Refining cost increase, cents } \\
\text { per physical gallon of } \\
\text { gasoline }\end{array}$} & $\begin{array}{l}2.44 \\
\text { to } \\
8.41\end{array}$ & 28.75 & $\begin{array}{l}15.21 \\
\text { to } \\
20.09\end{array}$ \\
\hline & $\begin{array}{l}4.92 \\
\text { to } \\
19.21\end{array}$ & 28.97 & $\begin{array}{l}13.10 \\
\text { to } \\
23.19\end{array}$ \\
\hline \multirow[t]{2}{*}{$\begin{array}{l}\text { Cost of crude reduction, } \$ \\
\text { per barrel }\end{array}$} & $\begin{array}{c}5.58 \\
\text { to } \\
15.71\end{array}$ & 66.06 & $\begin{array}{l}26.78 \\
\text { to } \\
32.90\end{array}$ \\
\hline & $\begin{array}{l}11.25 \\
\text { to } \\
46.03\end{array}$ & 66.34 & $\begin{array}{l}23.06 \\
\text { to } \\
45.60\end{array}$ \\
\hline
\end{tabular}




\section{GREENHOUSE GAS EMISSIONS OF LOW PETROLEUM GASOLINES}

Greenhouse gases (GHGs) impede the outward flow of infrared radiation more effectively than they impede incoming solar radiation, causing the earth to be warmer than it would be in the absence of GHGs. Some of the major GHGs which can be emitted by evaporation or combustion of fuels used by light duty vehicles are water vapor, carbon dioxide, nitrous oxide, and methane. Given the concerns about possible adverse effects of global warming, Section 502(b) of EAPCT requires the Secretary of Energy to determine the GHG emission implications of increasing the use of replacement fuels, including an estimate of the maximum feasible reduction in such emissions from the use of replacement fuels..

Although minimization of GHG emissions is not an objective of the low petroleum study, the GHG emissions of low petroleum study gasolines have been estimated with the component emissions data shown in Table 25. GHG emissions of individual gasolines are shown in the property tables of the appendices. Fig. 20 shows GHG emissions for low petroleum cases (with combined effects for RFG and CG). For summer cases:

Emissions are highest for corn-derived ethanol blends. ${ }^{2}$

Emissions are lowest for cellulosic ethyl ether blends.

With use of cellulosic ethanol, emissions decrease as the non-petroleum share of gasoline increases. Cellulosic ethyl ether blends have the greatest rate of decrease for GHG emissions.

For methyl ether blends, emissions decrease slightly as the non-petroleum share of gasoline increases.

Emissions of methyl ether blends are comparable to emissions of cellulosic ethanol blends.

For corn-derived ethanol and ethyl ether blends, emissions increase as the non-petroleum share of gasoline increases.

For winter cases, emissions are lowest for cellulosic ethanol and ethyl ether blends. Emissions are lower for winter cases compared to summer cases.

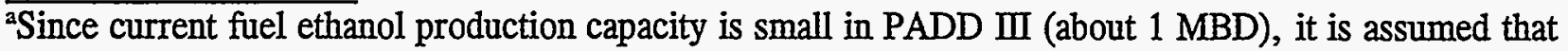
ethanol is supplied from new sources. GHG emissions for low petroleum gasolines blended with cornderived ethanol would be lower if ethanol were diverted from existing fuel uses, with ethanol replaced by $C G$ in the original use. 
Fig. 21 shows GHG emissions relative to the appropriate seasonal base case gasoline. Compared to the base case gasoline, GHG emissions are reduced for all methyl ether cases except for case $1 \mathrm{M}$, with low oxygenation (2.1 wt percent). Compared to base case gasolines, GHG emissions increase in all cornderived ethanol and ethyl ether cases, and the increases are substantial for ethanol cases. Compared to base case gasolines, GHG emissions decrease considerably for most cellulosic ethanol and ethyl ether blends. Depending on the mix of renewable ethanols used in low petroleum fuels, the relative change in GHG emissions could lie anywhere in the crosshatch area of a case in Fig. 21.

Fig. 21 shows that cellulosic ethanol could have substantial GHG emissions benefits in the future. $\mathrm{CO}_{2}$ released during biomass conversion to cellulosic ethanol and ethanol combustion would be absorbed during the growth of new biomass materials to replace those used during conversion. Other factors that could contribute to lower emissions of $\mathrm{CO}_{2}$ with cellulosic ethanol include reduced use of fertilizers, pesticides, tillage, and labor.

\begin{tabular}{||l|c||}
\hline \multicolumn{1}{|c|}{ Table 25. Greenhouse gas emissions of gasoline components ${ }^{46,47}$} \\
\hline Methyl ethers & $\begin{array}{c}\text { Greenhouse gas emissions } \\
\left(\mathrm{CO}_{2} \text { equivalent gm/BTU) }\right.\end{array}$ \\
\hline Ethyl ethers (corn-derived ethanol) & 0.10133 \\
\hline Ethyl ethers (cellulosic ethanol) & 0.11152 \\
\hline Corn-derived ethanol ${ }^{2}$ & 0.05494 \\
\hline Cellulosic ethanol & 0.13390 \\
\hline Summer hydrocarbon for CG & 0.00076 \\
\hline Winter hydrocarbon for CG & 0.10554 \\
\hline Summer hydrocarbon for RFG with MTBE & 0.10304 \\
\hline Winter hydrocarbon for RFG with MTBE & 0.10614 \\
\hline Summer hydrocarbon for RFG with ETBE & 0.10165 \\
\hline Winter hydrocarbon for RFG with ETBE & 0.10574 \\
\hline Summer hydrocarbon for RFG with corn-derived ethanol & 0.10165 \\
\hline Winter hydrocarbon for RFG with corn-derived ethanol & 0.11515 \\
\hline \hline aGHG emissions for corn-derived ethanol are from the base case in reference 48. \\
\hline \hline
\end{tabular}




\section{CONCLUSIONS}

The low petroleum study examines the effects of hypothetical low petroleum gasoline formulations on PADD III refinery operations and costs. The study cases do not provide forecasts of the volumes or mix of low petroleum gasolines that will enter the marketplace.

According to a DOE draft report, EPACT's 10 percent replacement fuel target for the year 2000 may be economically achievable through a combination of programs already in place and market incentives for the use of ethanol in some gasolines. ${ }^{50,51}$ Table 26 shows the projected components of fuel replacement. The non-petroleum share for the annual projection (with RFGs at 2.2 wt percent oxygen) is similar to the share for low petroleum case $1 \mathrm{M}$, in which methyl ethers are used to oxygenate summer RFG (at 2.1 wt percent oxygen).

The analysis of year 2010 summer production of low petroleum gasoline suggests that the 30 percent replacement fuel target can be achieved at a high cost. Compared to the Base case, incremental costs to meet the 30 percent low petroleum target could be more than three times the incremental costs to produce Phase II reformulated gasoline in PADD III (e.g, compare cases $6 \mathrm{E}$ and 1E). High oxygenation is the key to meeting the replacement fuel target, and a major contributor to cost increase is investment in processes to produce and etherify light olefins. High oxygenation can also increase the costs of control of RVP, distillation properties, and pollutant emissions of gasolines. Crude oil reduction, with decreased dependence on foreign sources, is a major objective of the low petroleum program. In the analysis, crude oil use is reduced by 10 to 17 percent.

There are uncertainties in the premises for study of low petroleum fuels production, and costs can be considerably different for alternative premises. There could be large cost impacts with different assumptions about:

Availability of cellulosic ethanol. For all ethanol and ethyl ether cases, costs and GHG emissions are substantially lower for use of cellulosic ethanol compared to corn-derived ethanol.

Extrapolation of the Complex Model beyond valid limits (as illustrated by ethyl ether cases $5 \mathrm{E}$ and $6 \mathrm{E}$ ). Emissions behavior is not known outside the range of the Complex Model, and vehicle testing is required to understand the costs and benefits of low petroleum gasolines with oxygen contents greater than 3.7 wt percent.

Availability of raw materials for ether production and availability and costs of imported ethers (as illustrated by cases $2 \mathrm{M}$ and $3 \mathrm{M}$ ).

The RVP for CG. The marginal costs for reduction of RVP have been used to estimate the cost savings for changing the summer CG RVP assumption from 7.9 psi to 8.7 psi (the cost savings will be overstated since the marginal cost should decrease as the RVP is increased). Fig. 22 shows the revised refining cost increases and the associated non-petroleum share. Compared with Fig. 9, the refining costs increases in Fig. 22 are more similar for alcohols and ethers. Appendix $E$ shows that cost revisions range from large for the ethanol cases with intermediate oxygenation to zero for seven cases, including all high oxygenation cases. 


\begin{tabular}{|c|c|c|}
\hline \multirow[t]{2}{*}{ Source } & \multicolumn{2}{|c|}{ Non-petroleum share (percent) } \\
\hline & $\begin{array}{l}\text { Year } 2000 \text { annual } \\
\text { projection (DOE } \\
\left.\text { draft report }^{50,51}\right)^{\mathrm{a}}\end{array}$ & $\begin{array}{l}\text { Low petroleum case } 1 \mathrm{M} \text { for year } \\
\qquad 2010 \text { summer }^{\mathrm{b}}\end{array}$ \\
\hline \multicolumn{2}{|l|}{$\begin{array}{l}\text { RFG and oxygenated gasoline for } \\
\text { carbon monoxide control: }\end{array}$} & \\
\hline With MTBE & 5.2 & \\
\hline With ethanol & 0.8 & \\
\hline With ETBE & 1.1 & \\
\hline Gasohol (10 percent ethanol in gasoline) & 0.3 & \\
\hline Conventional gasoline & 2.7 & \\
\hline Alternative fuel vehicles & 0.5 & \\
\hline Total & 10.5 & 10.1 \\
\hline \multicolumn{3}{|c|}{$\begin{array}{l}\text { aThis national projection is based on implementation of gasoline programs already in place. } \\
\text { Existing domestic capacity is used for production of oxygenates and reformulated gasoline } \\
\text { blendstocks. In the projection, } 50 \text { percent of gasoline is reformulated and has an average } \\
\text { oxygen content of } 2.2 \text { wt percent. Sufficient ethanol is used in the CG pool such that total fuel } \\
\text { ethanol use is } 1.4 \text { billion gallons per year (which is the estimated } 1995 \text { domestic ethanol } \\
\text { production capacity). The Renewable Oxygenate Standard, which requires that } 30 \text { percent of the } \\
\text { required oxygen content of RFG be derived from renewable oxygenates, is assumed to be in } \\
\text { effect. }\end{array}$} \\
\hline \multicolumn{3}{|c|}{$\begin{array}{l}\text { bow petroleum study case } 1 M \text { is for PADD III production of RFG with } 2.1 \text { wt percent oxygen } \\
\text { and CG with no oxygen. RFG production is } 62 \text { percent of total gasoline production. }\end{array}$} \\
\hline
\end{tabular}


Gasoline distillation specifications and engine operability with high percentages of ethers in gasoline.

Gasoline component blending properties (as illustrated by the displacement of alkylate with polymer gasoline due to distillation properties in cases $6 \mathrm{M}$ and $7 \mathrm{M}$ ). Over the broad range of oxygenation, it has been assumed that RVP and distillation blending properties are constant for individual oxygenates. Actually, these blending values have some variation.

Technology capability to process raw materials such as vegetable oils, and the quality of products of those technologies (as illustrated by cases $1 \mathrm{R}$ and $1 \mathrm{RX}$ ).

The accounting for low petroleum credit. An arbitrary procedure has been used for estimating the amount of non-petroleum-derived hydrogen that enters low petroleum gasoline.

Increased distribution costs for ethanol. These cost increases, which may be several cents per gallon of gasoline, are not included in the analysis.

The cost of capital.

Price assumptions. Fig. 23 illustrates the price elasticity effect on the cost for crude reduction for ethyl ether cases with use of corn-derived ethanol.

Compared with summer gasolines, emissions constraints are less stringent for winter gasolines, and production costs are lower. If the winter gasoline production season is 6.5 months, then year-round low petroleum gasoline with near-30 percent non-petroleum components might be achieved by combinations of cases, including:

Methyl ether cases 7M (summer, Table 13) and MW (winter, Table 24). Fig. 24 shows that the 7M/MW combination has an annualized refining cost increase of 37 cents per gallon of gasoline (elastic prices) and an annualized non-petroleum share of 29 percent. Crude oil use is reduced by 10 percent, at an annualized cost of $\$ 89$ per barrel; as shown in Fig. 25. Compared to base case gasolines, the $7 \mathrm{M} / \mathrm{MW}$ combination reduces $\mathrm{GHG}$ emissions by 0.5 percent, as shown in Fig. 26.

Ethyl ether cases 5E (summer, Table 16) and EW (winter, Table 24). Fig. 24 shows that the $5 \mathrm{E} / \mathrm{EW}$ combination has an annualized refining cost increase of 23 to 33 cents per gallon of gasoline (elastic prices) and an annualized non-petroleum share of 34 percent. Crude oil use is reduced by 12 percent, at an annualized cost of $\$ 48$ to $\$ 68$ per barrel, as shown in Fig. 25 . The lower costs are for use of cellulosic ethanol, and the higher costs are for use of corn-derived ethanol. Fig. 26 shows that the 5E/EW combination based on corn-derived. ethanol increases GHG emissions by 2.8 percent, compared to base case gasolines. However, the $5 \mathrm{E} / \mathrm{EW}$ combination based on cellulosic ethanol decreases GHG emissions by 15.9 percent, compared to base case gasolines.

- For the year-round cases, a refiner would not choose to produce low petroleum gasoline unless the average cost of crude in the base case is somewhere in the range of costs to reduce crude oil use: $\$ 48$ to $\$ 89$ per barrel. Fig. 1 shows that these crude oil costs are very high. 
Depending upon resolution of uncertainties about extrapolation of the Complex Model, availability of raw materials and other issues, the refining cost increases and the costs to reduce crude oil use could be could be lower or higher.

Finally, a mix of strategies could be less costly than any of the cases examined in this study. For example, costs might be lower with production of regional mixes of ether-based and ethanol-based gasolines in the winter, and with mixes of ether-based gasolines in the summer. 


\section{REFERENCES}

1. NPC 1991-92 Study of US Refining Industry, Table A-31, prepared by Turner, Mason \& Associates for the National Petroleum Council, $1625 \mathrm{~K}$ Street, N.W., Washington, DC, April $22,1992$.

2. Refinery Evaluation Modeling System (REMS) Documentation, DOE/EIA-0460, Energy Information Administration, Washington, DC, October 1984.

3. Refinery Evaluation Modeling System (REMS) Documentation, DOE/EIA-0461, Energy Information Administration, Washington, DC, October 1984.

4. M.R. Tallett, D.N. Dunbar, and J. Leather, Summary Documentation of Oak Ridge Refinery Yield Model Reformulated Gasoline Update, EnSys Energy \& Systems, Inc., Flemington, NJ, March 16, 1992.

5. M.R. Tallett and D.N. Dunbar, Enhancement of EIA Refinery Yield Model: Extension and Demonstration on Gasoline and Diesel Quality Issues, Oak Ridge National Laboratory Contract No. DE-AC05-840R21400, EnSys Energy \& Systems, Inc., Flemington, NJ, August 1988.

6. D. Korotney, Revised Complex Model for Conventional and Reformulated Gasoline, EPA Air Docket A-92-12, Environmental Protection Agency, Ann Arbor, MI.

7. API Refining Cost Study of Potential EPA FCAAA Regs for 2000, Table B-10, prepared by Turner, Mason \& Associates for the American Petroleum Institute, $1220 \mathrm{~L}$ Street, NW, Washington, DC, August 11, 1993.

8. NPRA Survey of U.S. Gasoline Quality and U.S. Refining Industry Capacity to Produce Reformulated Gasolines, Part A, National Petroleum Refiners Association, Suite 1000, 1899 L Street, NW, Washington, DC, January 1991.

9. NPC 1991-92 Study of US Refining Industry, Table A-2, prepared by Turner, Mason \& Associates for the National Petroleum Council, $1625 \mathrm{~K}$ Street, N.W., Washington, DC, September 9, 1992.

10. R.B. Warden, "NPC Refining Study, Product Quality Task Group Issue Document: Issue No.: F-1,2,3 \& R-1,2," National Petroleum Council, 1625 K Street, N.W., Washington, DC, March $5,1992$.

11. R.B. Warden, "Impact of CAA on Fuel Economy," National Petroleum Council, $1625 \mathrm{~K}$ Street, N.W., Washington, DC, graph, January 26, 1992.

12. NPC 1991-92 Study of US Refining Industry, Table A-26 (June 25, 1992) and Table D1-1A (September 17, 1992), prepared by Turner, Mason \& Associates for the National Petroleum Council, 1625 K Street, N.W., Washington, DC, 1992. 
13. Energy Information Administration, U.S. Department of Energy, Petroleum Supply Annual 1993, DOE/EIA-0340(93)/1, Washington, DC, June 1994.

14. Energy and Environmental Analysis, Inc., "Specifications for Low Petroleum Gasoline," 1655 North Fort Meyer Drive, Arlington, VA.

15. National Institute for Petroleum and Energy Research, "Motor Gasoline Survey, Winter 19921993," Bartlesville, OK.

16. Downstream Alternatives, Inc., Changes in Gasoline II, P.O. Box 109, Bremen, IN, July 1992.

17. L.D. Palmer and B.V. Copson, "Hydrotreatment of Light Cycle Oil for Stabilization of Automotive Diesel Fuel," Conference Proceedings, 2nd International Conference on Long-Term Storage Stabilities of Liquid Fuels, Southwest Research Institute, San Antonio, TX, July 29 August 1, 1986, pp. 902-914.

18. M.W. Schrepfer, R.J. Arnold, and C.A. Stansky, "Distillate Stability Ensured by Testing, Treatment," Oil \& Gas Journal, January 16, 1984, pp. 79-84.

19. D.R. Hardy, R.N. Hazlett, and E.W. White, "Assessment of Storage Stability Additives for Naval Distillate Fuel," Conference Proceedings, 2nd International Conference on Long-Term Storage Stabilities of Liquid Fuels, Southwest Research Institute, San Antonio, TX, July 29 August 1, 1986, pp. 887-901.

20. ARCO Products Company, Carson, CA.

21. Energy Information Administration, U.S. Department of Energy, Annual Energy Outlook 1994, DOE/EIA-0383(94), Washington, DC, January 1994.

22. "Mix of reasons underpins rise in downstream U.S. earnings," Oil \& Gas Journal, September $15,1986$.

23. NPC 1991-92 Study of US Refining Industry, Tables A-13, prepared by Turner, Mason \& Associates for the National Petroleum Council, $1625 \mathrm{~K}$ Street, N.W., Washington, DC, April $21,1992$.

24. Final Regulatory Impact Analysis for Reformulated Gasoline, Environmental Protection Agency, December 1, 1993, p. 330.

25. U.S. Department of Energy, Estimating the Costs and Effects of Reformulated Gasolines, DOE/PO-0030, Office of Policy, December 1994.

26. D. Haverkamp, personal communication with G.M. Webb, Energy and Environmental Analysis, Inc., Arlington, VA, 1994. 
27. U.S. Department of Energy, An Evaluation of Factors Contributing to the Potential for Regional Propane Market Disruptions in the United States, DOE?PO-0002, prepared by Energy and Environmental Analysis.

28. R. Haun, K. Otto, and S. Whitley, "Growing Worldwide Gas Processing Market Improving," Oil \& Gas Journal, June 13, 1994.

29. American Petroleum Institute, Basic Petroleum Data Book, Volume XIV, Number 3, Section VII, Tables 16-16c, September 1994.

30. W. True, "World's Gas Processing Growth Slows; U.S., Canada Retain Greatest Share," Oil \& Gas Journal, June 13, 1994.

31. R. Hugman, P. Springer, E. Vidas, Chemical Composition of Discovered and Undiscovered Natural Gas in the United States - 1993 Update, Volume I: Project Summary, prepared by Energy and Environmental Analysis, Inc., for the Gas Research Institute, December 1993.

32. C. Tannehill and J. Gibbs, Evaluation of Hydrocarbon Liquid Disposition: Topical Report (July November 1990), prepared by Purvin \& Gertz, Inc., for the Gas Research Institute, Revised July 1991.

33. Energy Information Administration, U.S. Department of Energy, Annual Energy Outlook 1994, DOE/EIA-0383(93), Washington, DC, January 1993.

34. M.S. Lorenzetti, "Alcohols Continue Important Role in Motor Fuel Mix," Fuel Reformulation.

35. M. Czeskleba, "Ethanol Can Be Economical for RFG," Octane Week, Vol. VII, No. 31, December 31, 1993.

36. "ARCO Chemical Unable To Sell ETBE Due to Tax Credit Limits," Oxy-Fuel News, Vol. VI, No. 26, July 4, 1994.

37. P.S. Hu, S.C. Davis, C.M. Hansen, M. Mintz, T. Snyder, A. Vyas, and M.Q. Wang, Preliminary Assessment on the Potential Coverage of Alternative Fuel Industries under EPACT Section 501, Draft, Oak Ridge National Laboratory, Oak Ridge, TN, June 1994.

38. U.S. Department of Energy, Assessment of Costs and Benefits of Flexible and Alternative Fuel Use in the U.S. Transportation Sector, DOE/EP-0004, Office of Domestic and International Energy Policy, January 1993.

39. R.C. Anderson, T.J. Lareau, and R.D. Wollstadt, The Economics of Gasoline Ethanol Blends, Research Study Number 045, American Petroleum Institute, 1220 L Street, NW, Washington, DC, November 1988.

40. D.E. Melville and R.A. Korus, "Process Description and Economics of Rapeseed Methyl Ester Production," The Potential of Vegetable Oil as an Alternate Source of Liquid Fuel for Agriculture in the Pacific Northwest - V, University of Idaho, Moscow, ID, 1986-1987. 
41. Y.S. Prasad, N.N. Bakhshi, J.F. Mathews, and R.L. Eager, "Catalytic Conversion of Canola Oil to Fuels and Chemical Feedstocks Part I. Effect of Process Conditions on the Performance of HZSM-5 Catalyst," The Canadian Journal of Chemical Engineering, Vol. 64, April 1986.

42. Y.S. Prasad, N.N. Bakhshi, J.F. Mathews, and R.L. Eager, "Catalytic Conversion of Canola Oil to Fuels and Chemical Feedstocks Part II. Effect of Co-feeding Steam on the Performance of HZSM-5 Catalyst," The Canadian Journal of Chemical Engineering, Vol. 64, April 1986.

43. K. Bormann, H. Tilgner, and H.-J. Moll, "Rape Seed Oil as a Feed Component of Catalytic Cracking Process," Erdoel Erdgas Kohle (Germany), April 1993.

44. P.B. Weisz, W.O. Haag, and P.G. Rodewald, "Catalytic Production of High-Grade Fuel (Gasoline) from Biomass Compounds by Shape-Selective Catalysis," Science, Vol. 206, October $5,1979$.

45. George DeValis, U.S. Department of Agriculture, USDA-ERS, Washington, DC, June 1994.

47. K. Stork and M. Singh, The Impact of the Renewable Oxygenate Standard for Reformulated Gasoline on Ethanol Demand, RFG Energy Use and RFG Greenhouse Gas Emissions, draft report, Argonne National Laboratory, Washington, DC, January 1995.

48. K. Stork, Argonne National Laboratory, Argonne, IL, February 1995.

49. M.A. Delucchi, Emissions of Greenhouse Gases from the Use of Transportation Fuels and Electricity, ANL/ESD/TM-22, Argonne National Laboratory, Argonne, IL, November 1991.

50. K. Stork, Argonne National Laboratory, Argonne, IL, November 15, 1994.

51. E.H. Vidas, B. Tuthill, and D.S. Haverkamp, An Assessment of the Market Benefits of Alternative Motor Vehicle Fuel Use, prepared for U.S. Department of Energy, Office of Policy Integration, by Energy and Environmental Analysis, Inc., Arlington, VA, November 15, 1994. 


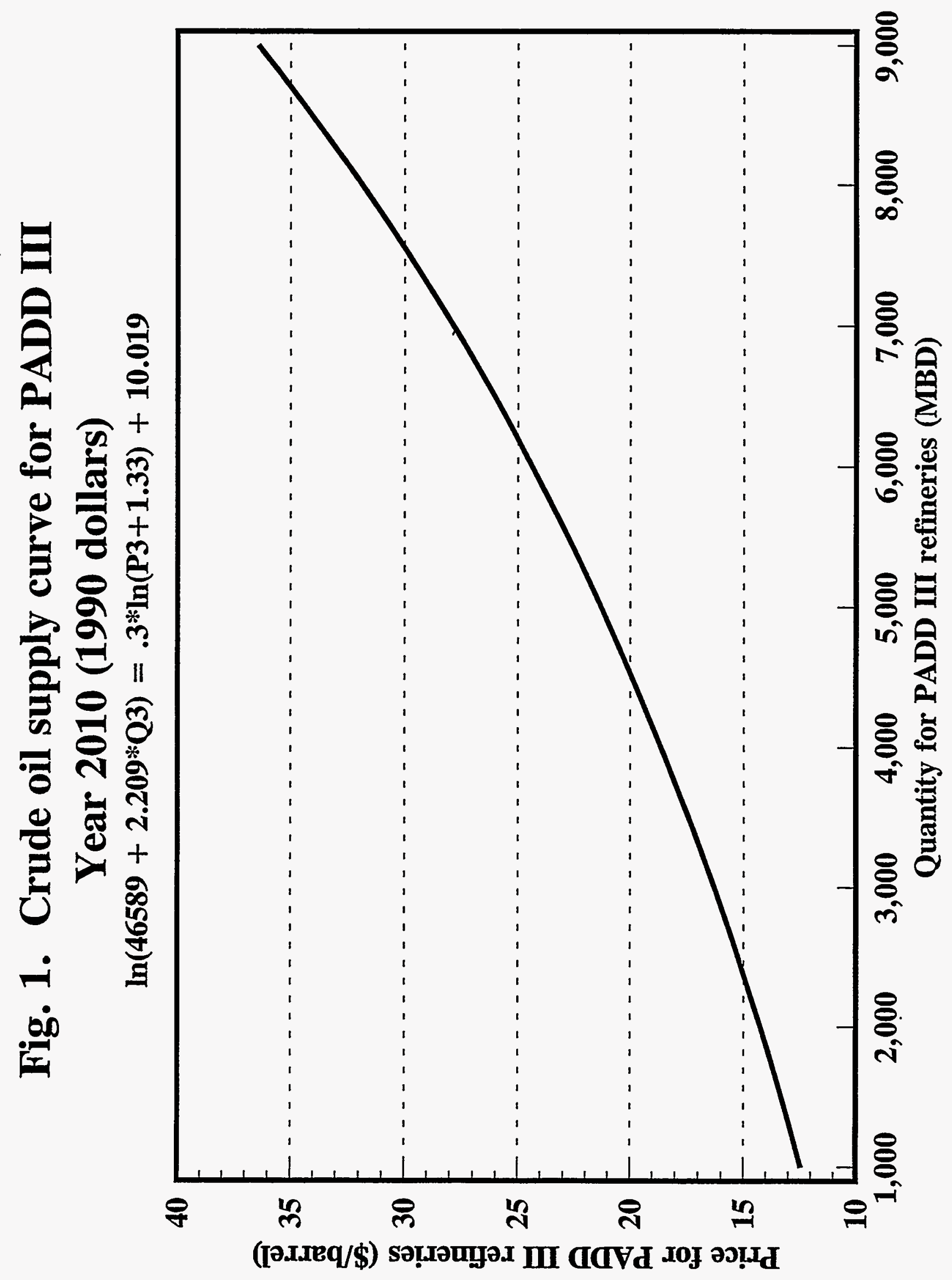




\section{Fig. 2. Natural gas supply curve for PADD III Year 2010 (1990 dollars) \\ $\ln (76066+1.47 * \mathrm{Q} 3)=.3 * \ln (\mathbf{P 3 - 0 . 4 3 7})+10.918$}

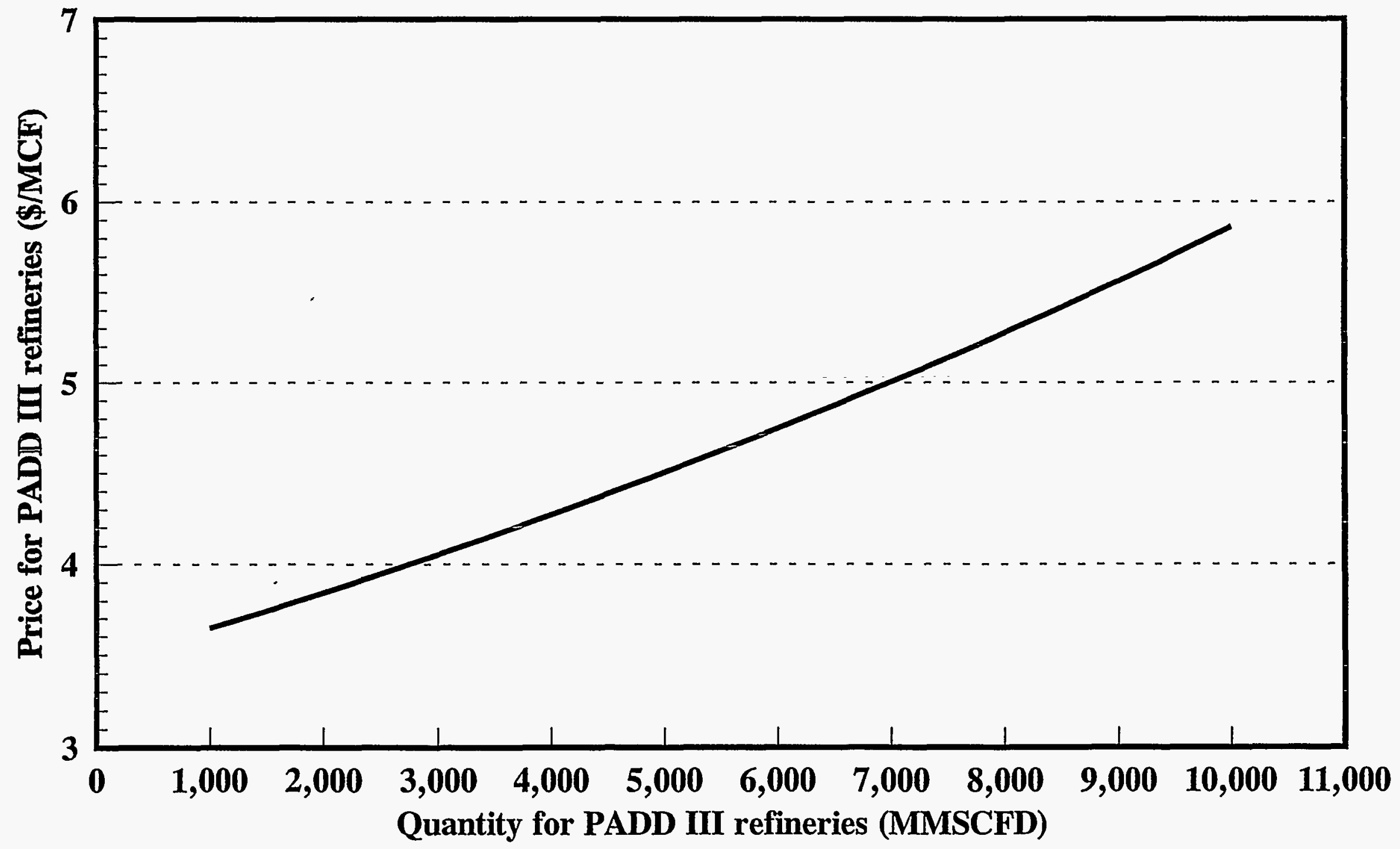




\section{Fig. 3. Corn-derived ethanol supply curve PADD III, year 2010 (1990 dollars)}

$\ln (2.25 * \mathrm{Q} 3)=4.35 * \ln (\mathrm{P3}-17.38)-6.7449$

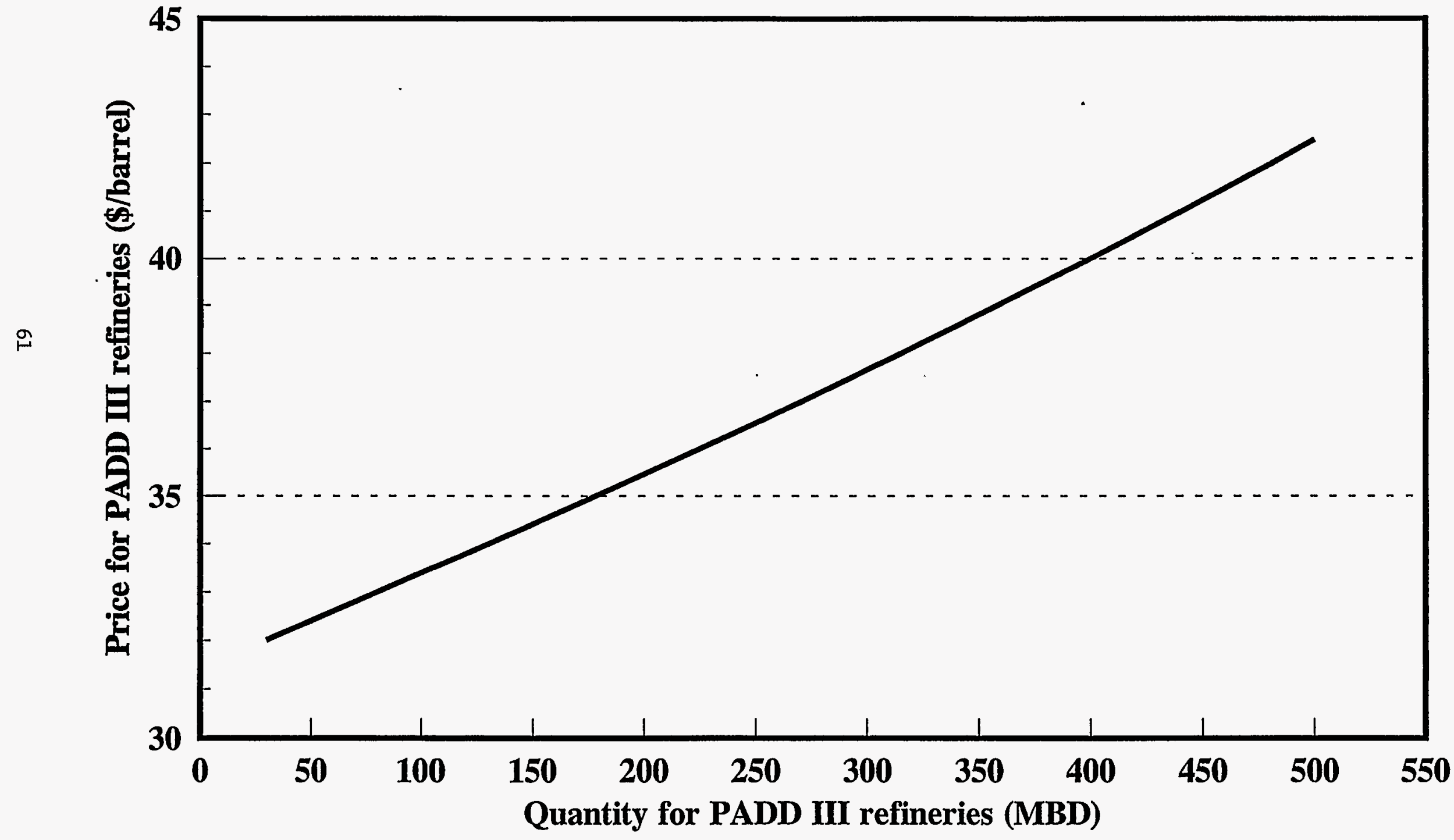


FIGUAR 4

Low Petroleum Gasoline: Possible Petroleum Displacement Sources

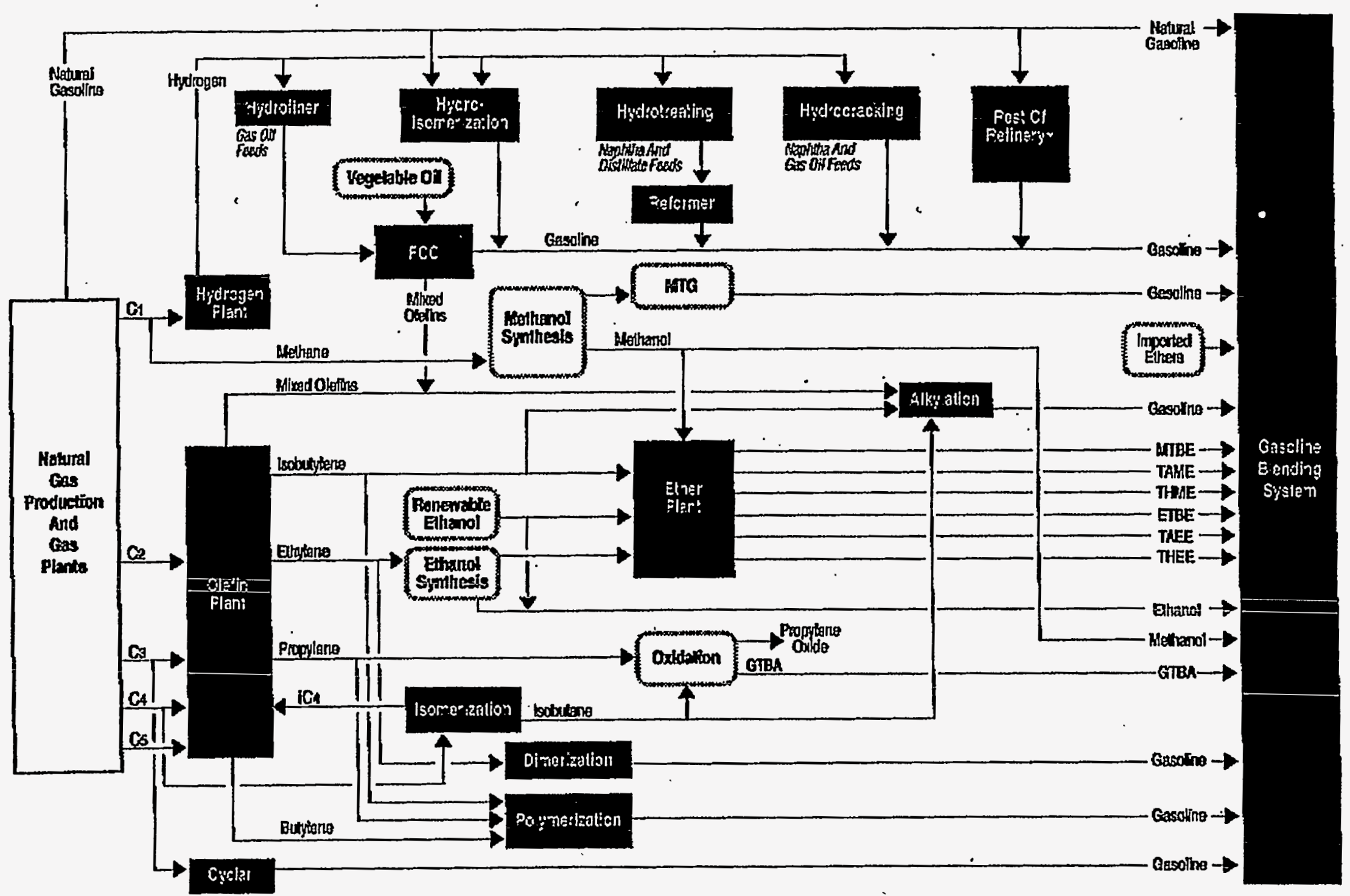

Exksing Refingsy Unth 


\section{Fig. 5. RFG and blendstock VOC emissions values}

(Some values can vary with case)

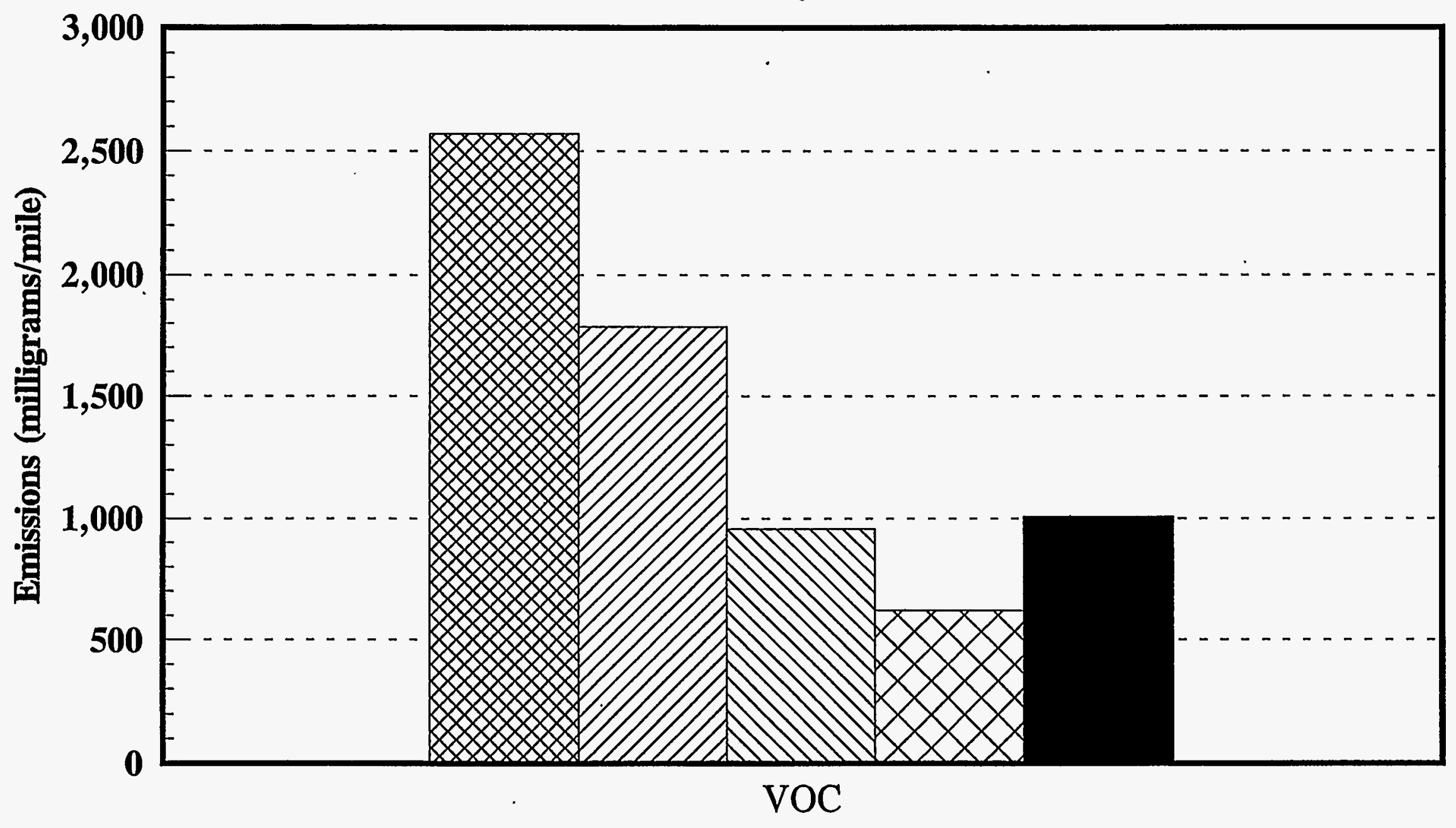

Methanol + GTBA $\square$ Ethanol $\triangle$ MTBE \& ETBE $\square$ RFG RFG emissions are target specifications.

Other emissions are blending values. 


\section{Fig. 6. NOx and VOC sensitivity to oxygen from methyl ethers \\ (PADD III, year 2010, Phase II summer)}

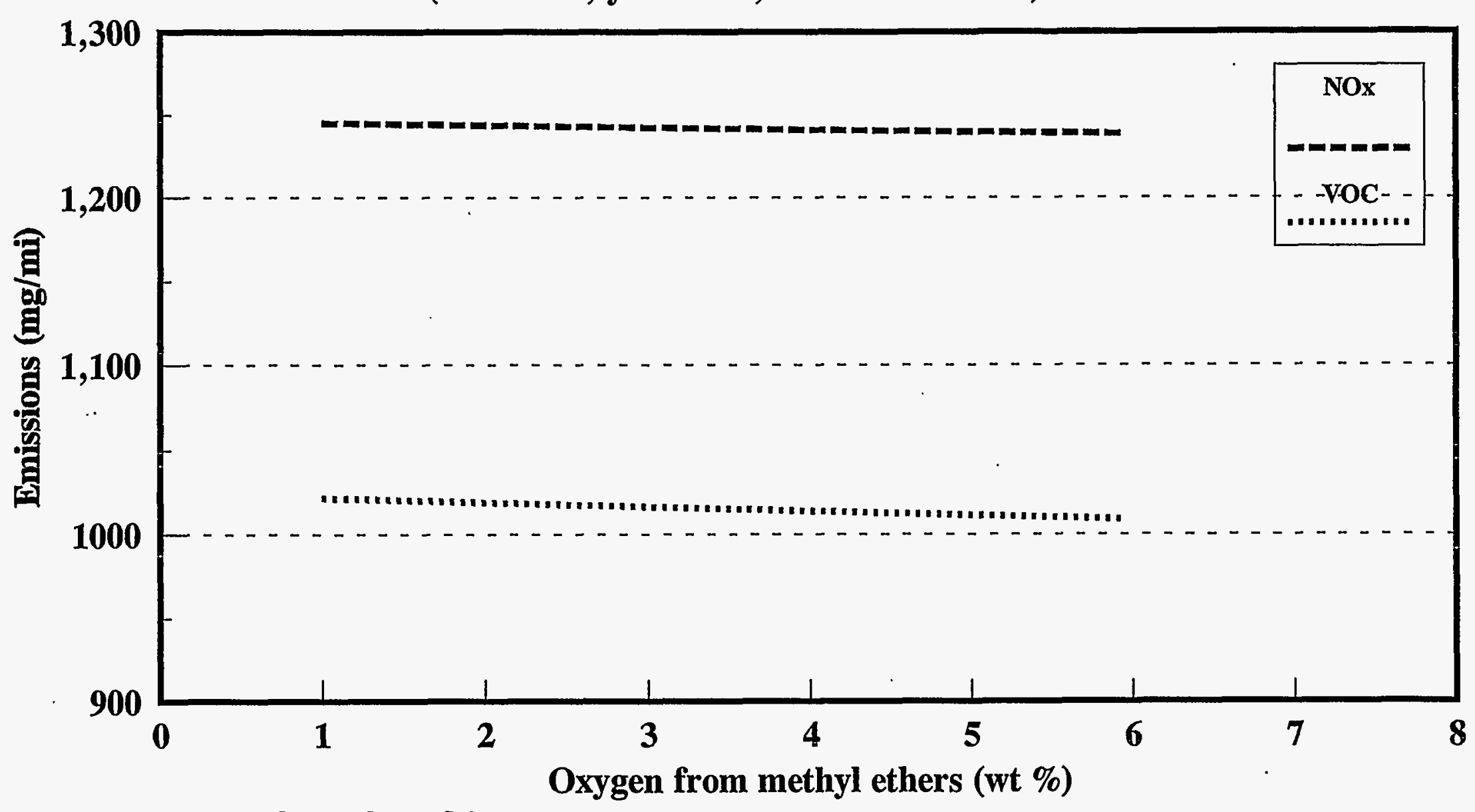

Oxygen content is varied around case $6 \mathrm{M}$.

Oxygen $>3.7 \%$ is outside valid range of

Complex Model. 


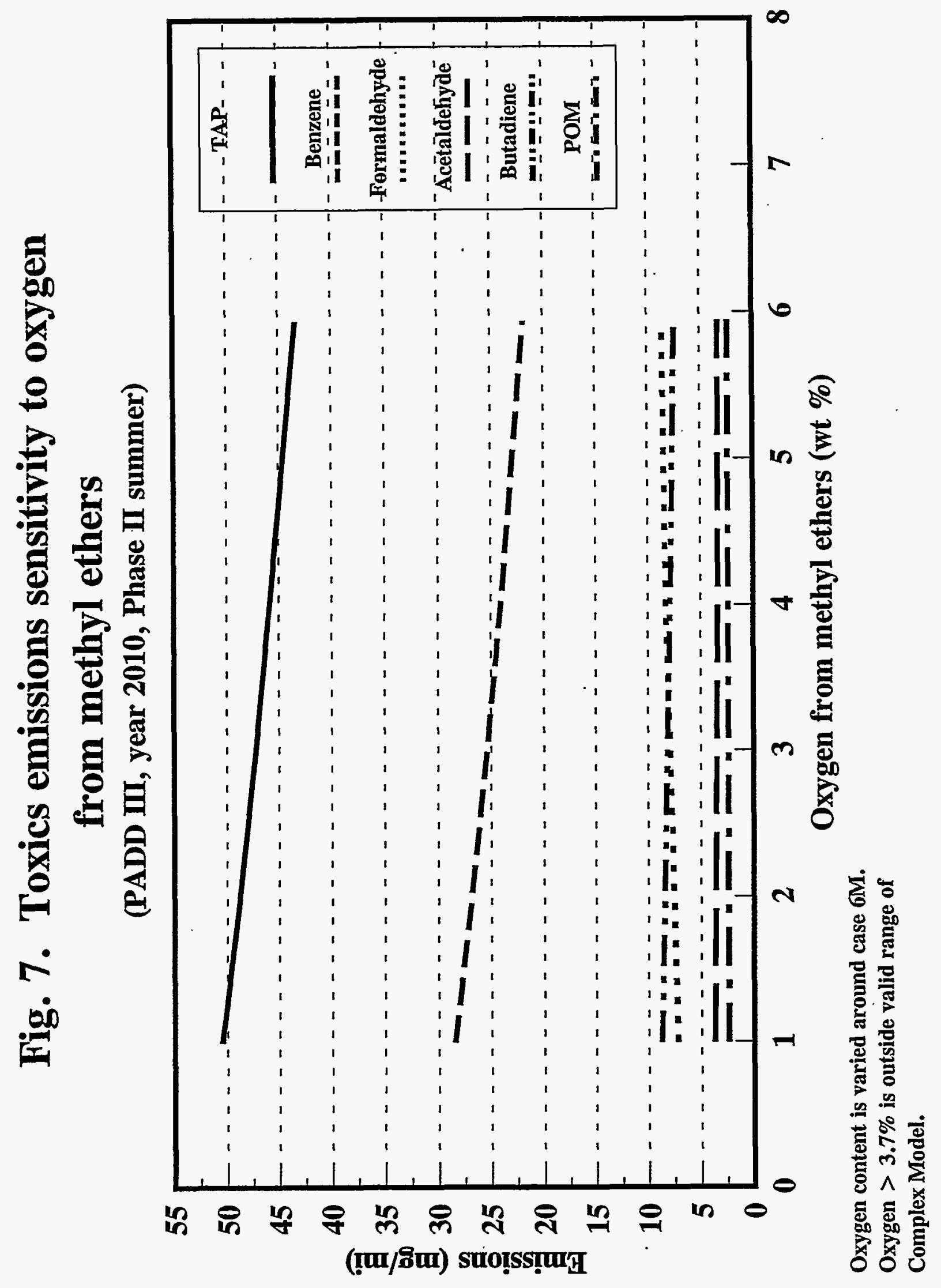




\section{Fig. 8. Toxics emissions sensitivity to oxygen from ethyl ethers \\ (PADD III, year 2010, Phase II summer)}

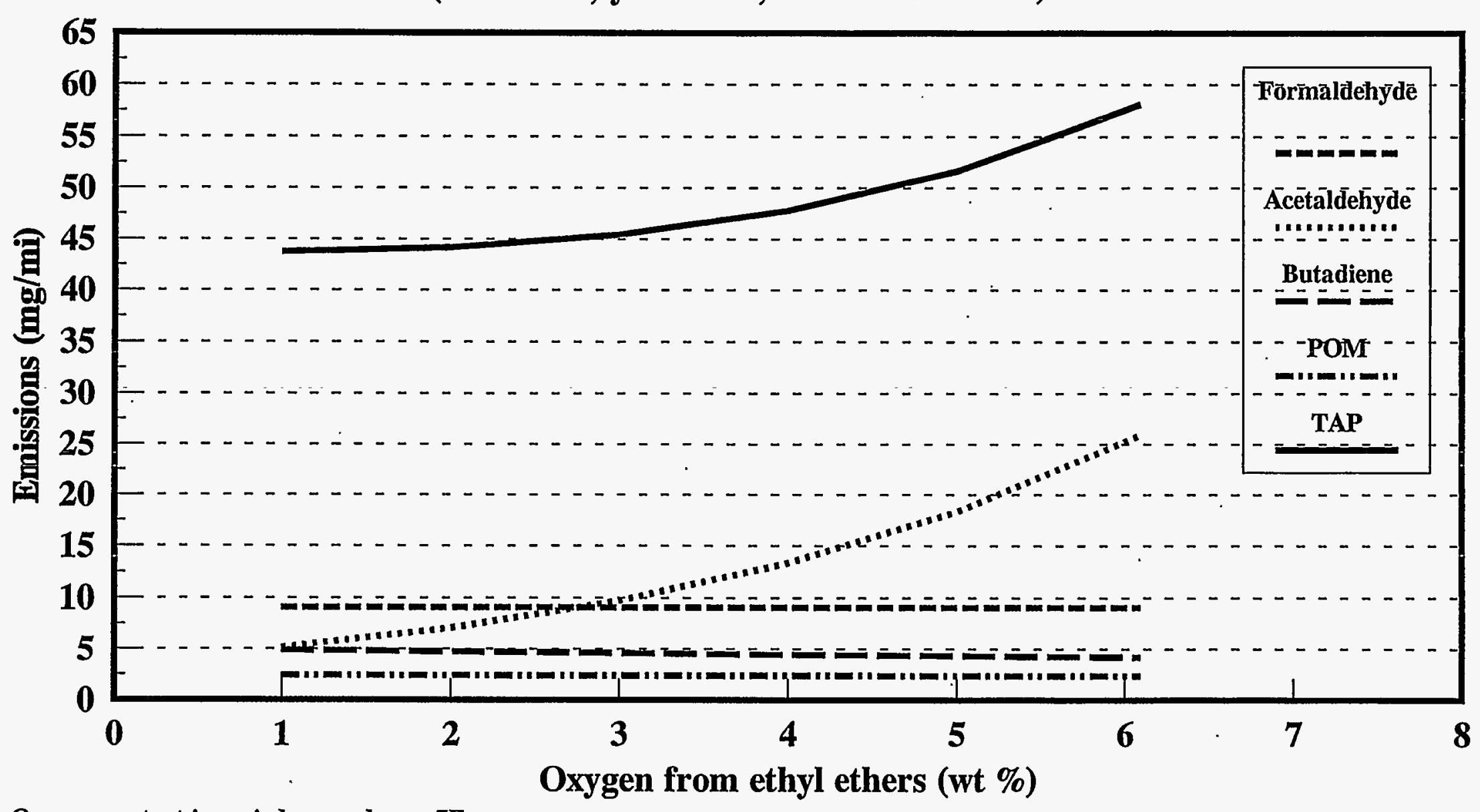

Oxygen content is varied around case 7E. Oxygen $>3.7 \%$ is outside valid range of Complex Model. 


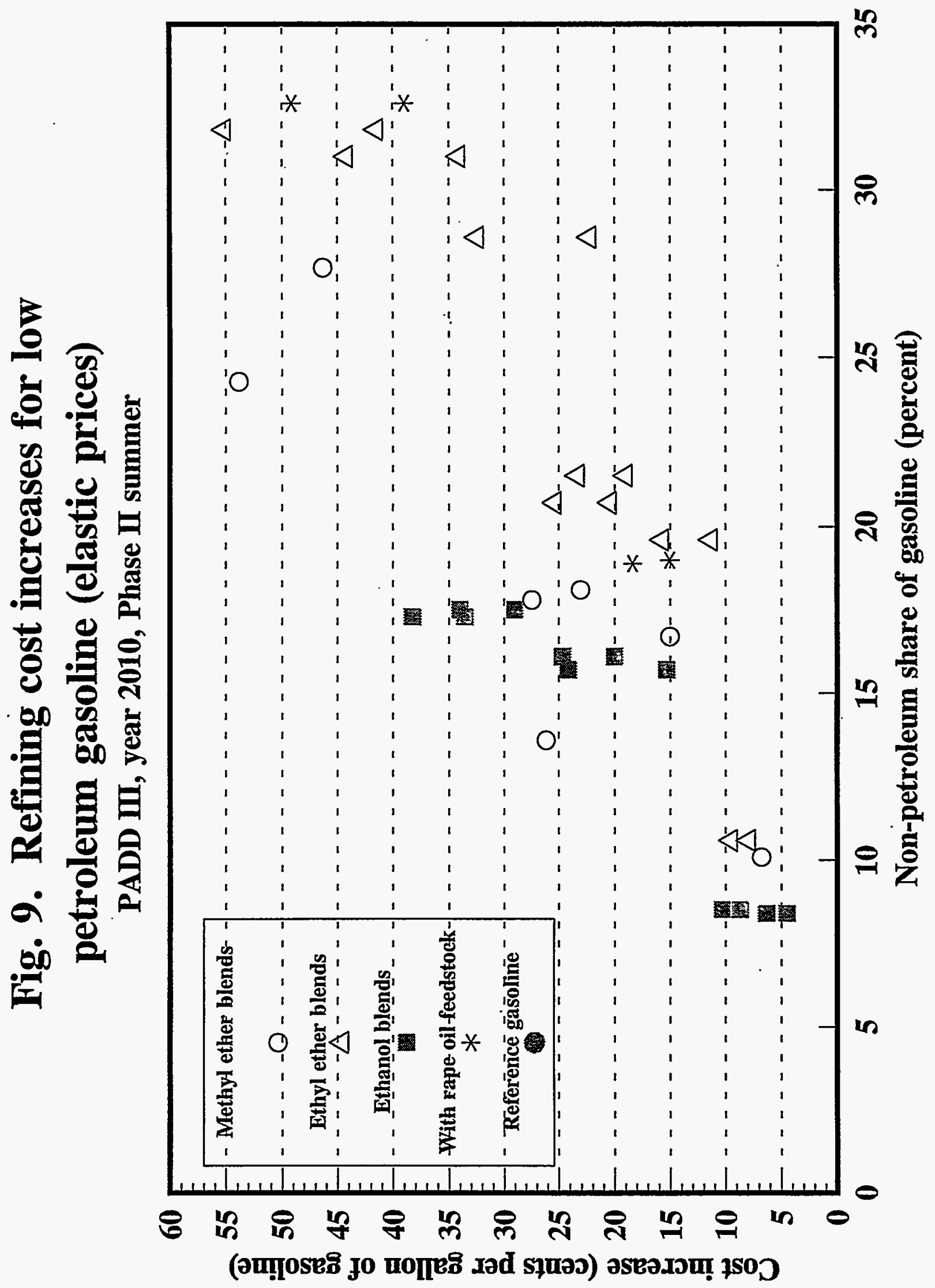




\section{Fig. 10. Refining cost increase for low petroleum gasoline cases (elastic prices) \\ PADD III, year 2010, Phase II summer}

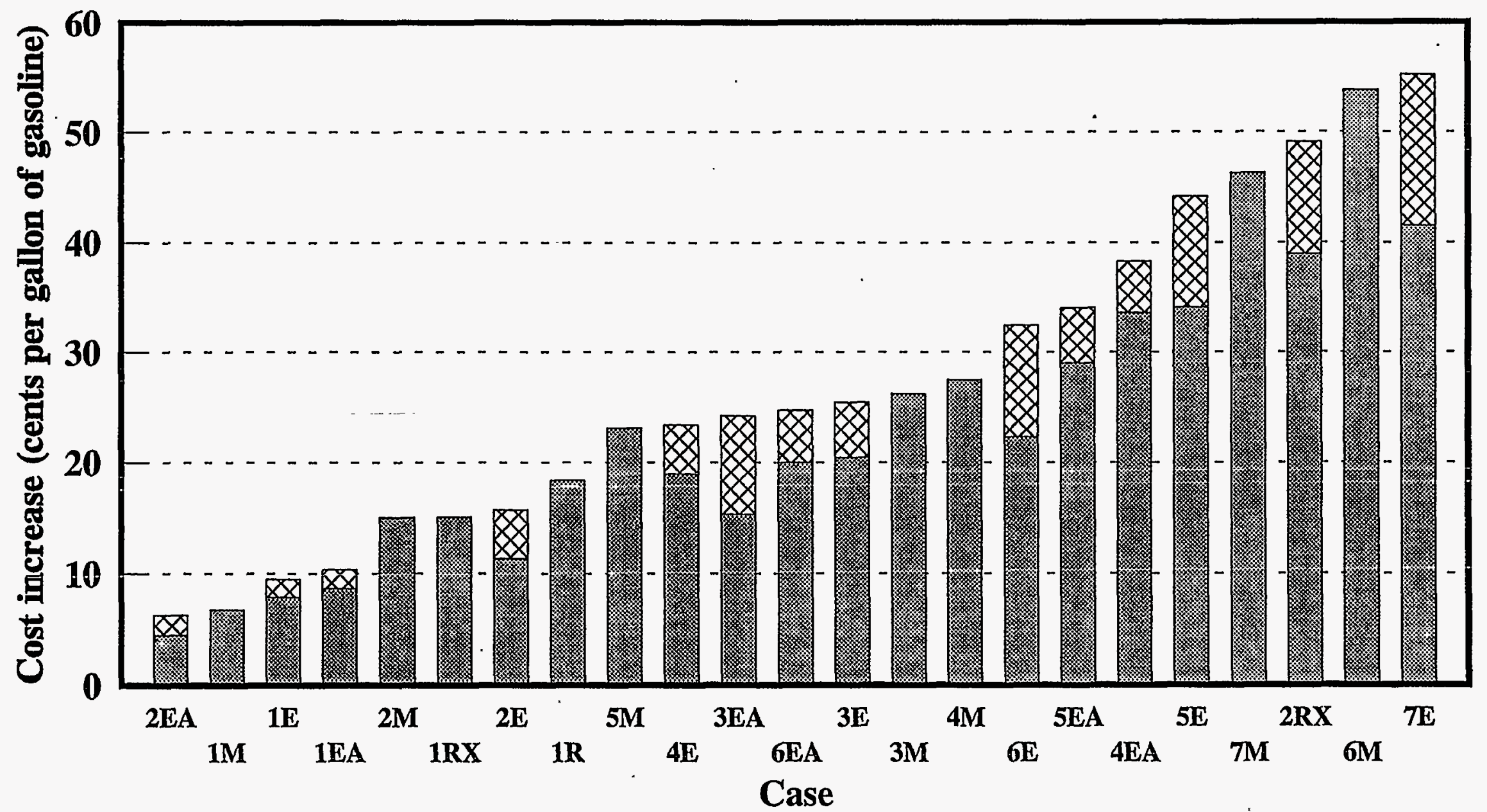

Crosshatch shows cost increase range due to ethanol cost differences. Low end of range: cellulosic; high end of range: corn-derived. 


\section{SUPPLEMENT TO FIGURES}

\begin{tabular}{|c|c|c|c|c|c|c|}
\hline \multicolumn{7}{|c|}{ Ethanol summer case descriptions } \\
\hline Case & 1EA & $2 \mathrm{EA}$ & $3 \mathrm{EA}$ & $4 \mathrm{EA}$ & $5 \mathrm{EA}$ & $6 \mathrm{EA}$ \\
\hline RFG oxygen target, wt\% & 2.1 & 2.1 & 2.7 & 2.7 & 2.7 & 2.7 \\
\hline CG oxygen target, wt\% & & & 3.5 & 3.5 & 3.5 & 3.5 \\
\hline $\begin{array}{l}\text { Crude reduction target, } \\
\text { vol\% }\end{array}$ & & & 10 & 15 & 15 & 10 \\
\hline Forced hydrogenation? & No & No & No & No & No & Yes \\
\hline RFG VOC reduction, $\min \%$ & 30 & 24 & 30 & 30 & 30 & 30 \\
\hline CG RVP, max psi & 7.9 & 7.9 & 7.9 & 7.9 & 8.7 & 7.9 \\
\hline
\end{tabular}

\begin{tabular}{||l||c|c|c|c|c|c|c||}
\hline \multicolumn{7}{|c||}{ Methyl ether summer case descriptions } \\
\hline Case & n & $2 \mathrm{M}$ & $3 \mathrm{M}$ & $4 \mathrm{M}$ & 5M & $6 \mathrm{M}$ & $7 \mathrm{M}$ \\
\hline \hline RFG oxygen target, wt\% & 2.1 & 2.7 & 2.7 & 2.7 & 2.7 & 6.0 & 6.0 \\
\hline CG oxygen target, wt\% & & 3.5 & 3.5 & 3.5 & 3.5 & 6.0 & 6.0 \\
\hline $\begin{array}{l}\text { Crude reduction target, } \\
\text { vol\% }\end{array}$ & & 10 & 10 & 15 & 10 & 10 & 10 \\
\hline $\begin{array}{l}\text { Oxygenate imports } \\
\text { allowed, vol\% }\end{array}$ & 43 & 43 & 0 & 43 & 43 & 43 & 71 \\
\hline Forced hydrogenation? & No & No & No & No & Yes & No & No \\
\hline
\end{tabular}




\section{SUPPLEMENT TO FIGURES (Continued)}

\begin{tabular}{|c|c|c|c|c|c|c|c|}
\hline \multicolumn{8}{|c|}{ Ethyl ether summer case descriptions } \\
\hline $\mathrm{Case}_{4}+4$. & $\sqrt{1 \mathrm{E}}$ & $2 E$ & $3 \mathrm{E}$ & $4 \mathrm{E}$ & $\mathrm{SE}$ & $6 \mathrm{E}$ & $7 \mathrm{E}$ \\
\hline RFG oxygen target, wt\% & 2.1 & 2.7 & 2.7 & 2.7 & 6.0 & 6.0 & 6.0 \\
\hline CG oxygen target, wt\% & & 3.5 & 3.5 & 3.5 & 6.0 & 6.0 & 6.0 \\
\hline $\begin{array}{l}\text { Crude reduction target, } \\
\text { vol\% }\end{array}$ & & 10 & 15 & 10 & 10 & 10 & 17 \\
\hline $\begin{array}{l}\text { Oxygenate imports allowed, } \\
\text { vol\% }\end{array}$ & 43 & 43 & 43 & 43 & 43 & 43 & 43 \\
\hline Forced hydrogenation? & No & No & No & Yes & No & No & No \\
\hline $\begin{array}{l}\text { Linear acetaldehyde } \\
\text { emissions? }\end{array}$ & No & No & No & No & No & Yes & No \\
\hline
\end{tabular}

\begin{tabular}{|l|c|c|c|c|c|c||}
\hline \multicolumn{5}{|c|}{ Rapeseed summer case descriptions } \\
\hline Sase \\
\hline \hline RFG oxygen target, wt\% & 2.7 & 2.7 & 2.7 & 6.0 & 6.0 \\
\hline CG oxygen target, wt\% & 3.5 & 3.5 & 3.5 & 6.0 & 6.0 \\
\hline $\begin{array}{l}\text { Ether type } \\
\text { (M = methyl; E = ethyl) }\end{array}$ & $\mathrm{M}$ & $\mathrm{M}$ & $\mathrm{M}$ & $\mathrm{E}$ & $\mathrm{E}$ \\
\hline $\begin{array}{l}\text { Crude reduction target, } \\
\text { vol\% }\end{array}$ & 10 & 10 & 10 & 10 & 10 \\
\hline $\begin{array}{l}\text { Oxygenate imports allowed, } \\
\text { vol\% }\end{array}$ & 43 & 43 & 43 & 43 & 43 \\
\hline Forced hydrogenation? & No & No & No & No & No \\
\hline Rapeseed oil feed? & No & Yes & Yes & No & Yes \\
\hline $\begin{array}{l}\text { FCC naphtha (rapeseed } \\
\text { derived) quality }\end{array}$ & NA & Low & Hig & NA & High \\
\hline \hline
\end{tabular}




\section{SUPPLEMENT TO FIGURES (Continued)}

\begin{tabular}{||l|c|c|c||}
\hline \multicolumn{3}{|c|}{ Winter case descriptions } \\
\hline Casee & EAV & MW & EWW \\
\hline \hline RFG oxygen target, wt\% & 6.0 & 6.0 & 6.0 \\
\hline CG oxygen target, wt\% & 6.0 & 6.0 & 6.0 \\
\hline Oxygenate type & Ethanol & Methyl ethers & Ethyl ethers \\
\hline Crude reduction target, vol\% & 10 & 10 & 10 \\
\hline Oxygenate imports allowed, vol\% & 100 & 66 & 70 \\
\hline
\end{tabular}




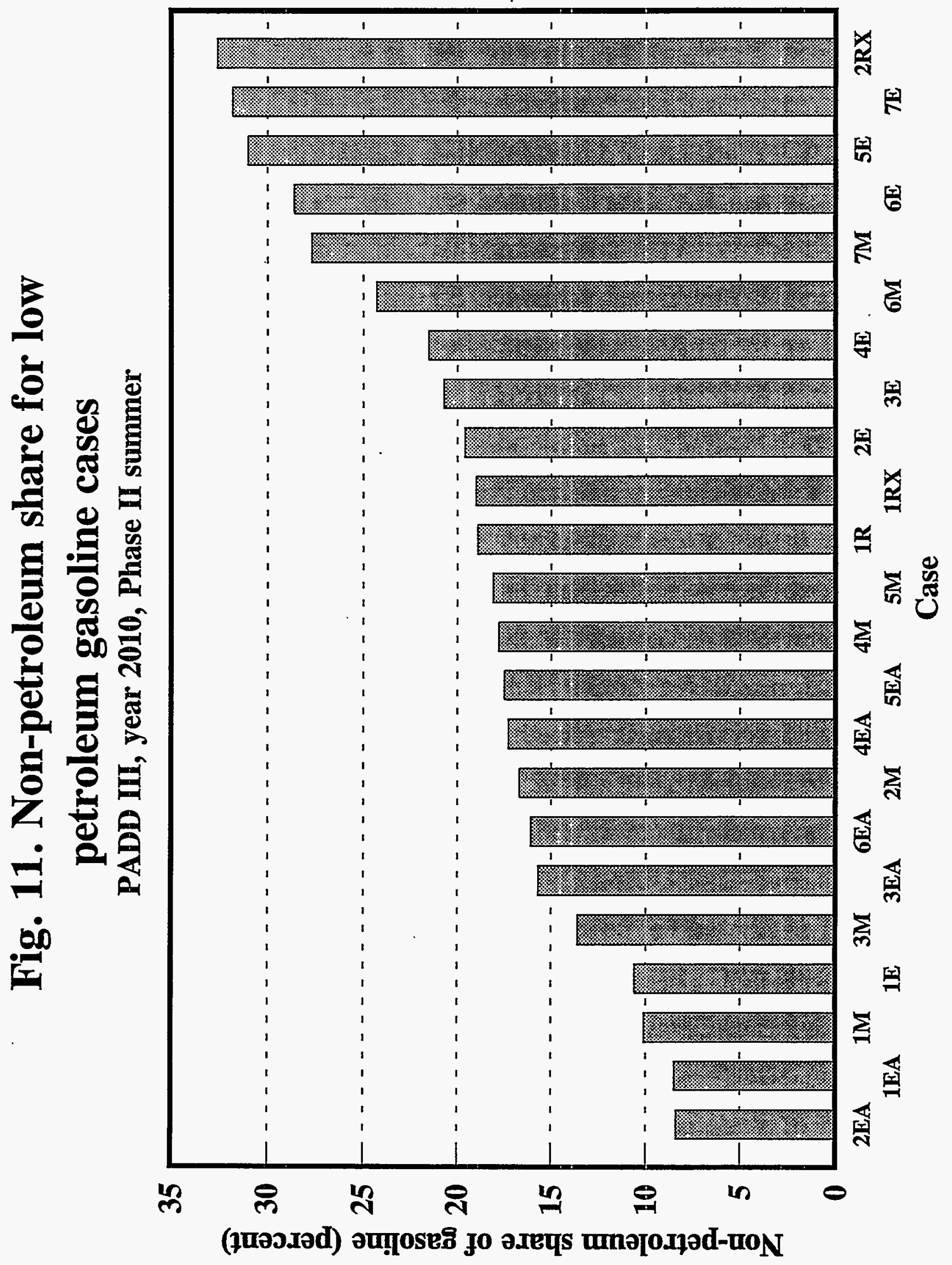




\section{Fig. 12. Cost to reduce crude oil use in low petroleum gasoline policy (elastic prices) \\ PADD III, year 2010, Phase II summer}

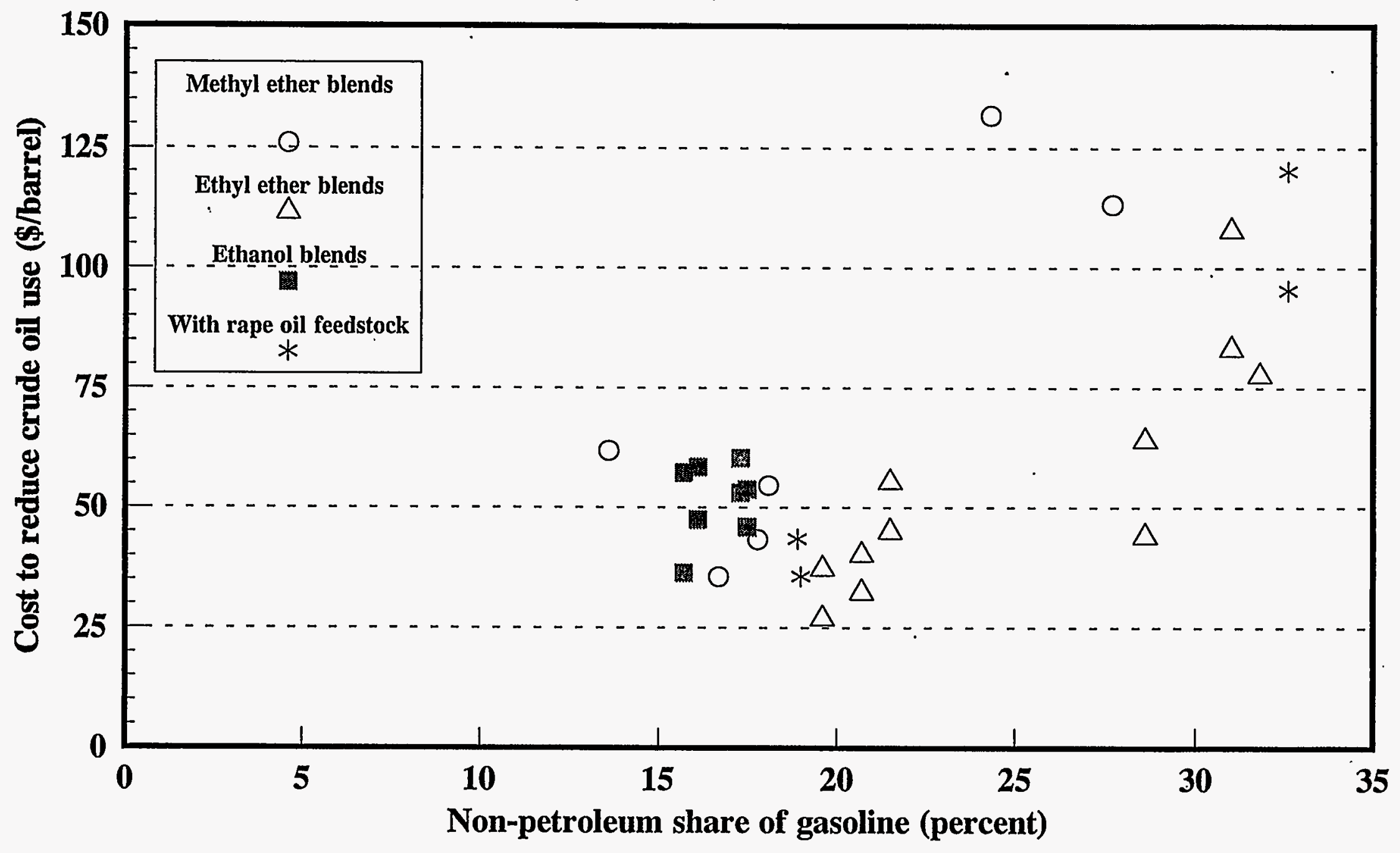




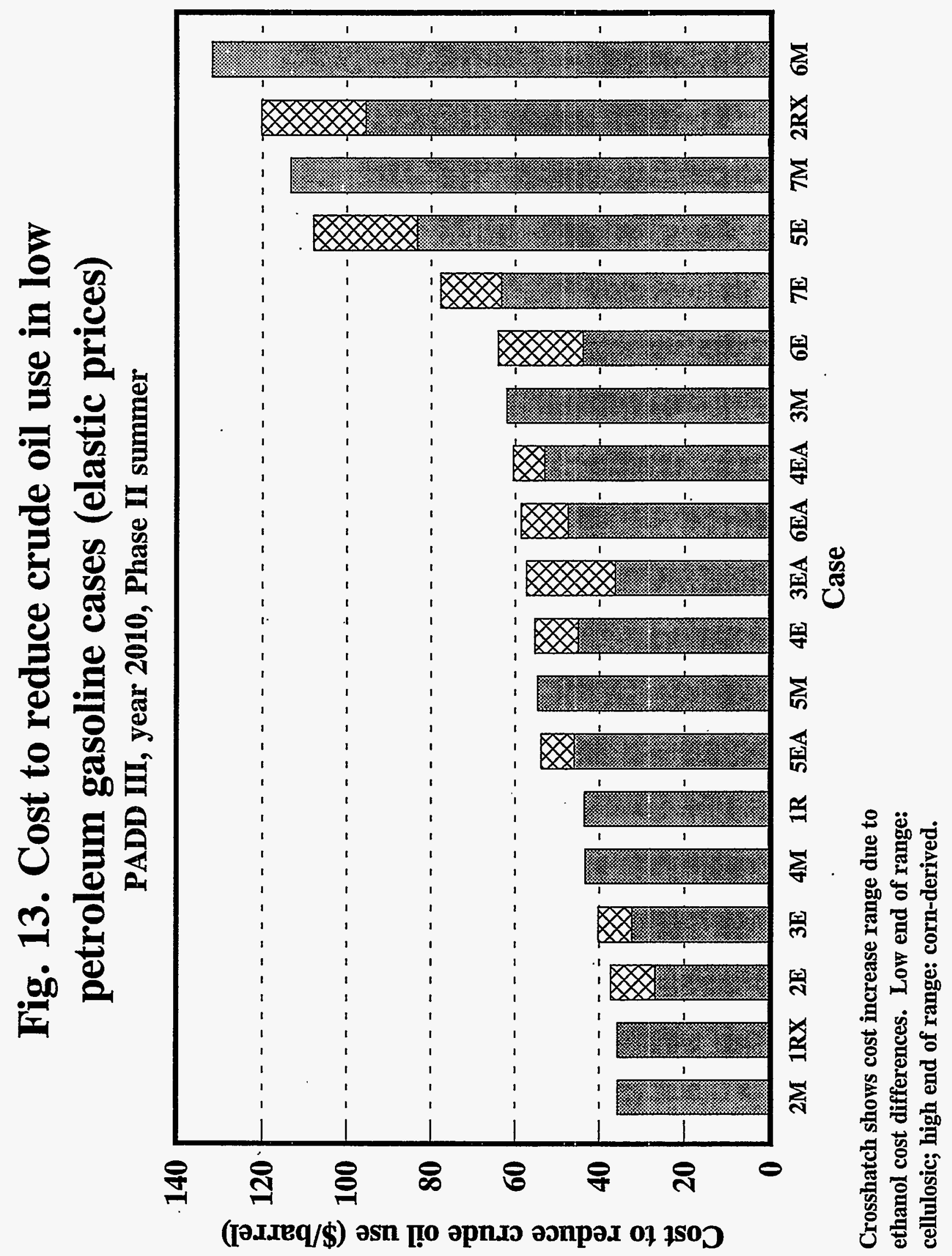




\section{Fig. 14. Crude oil use reduction in low petroleum gasoline policy \\ (PADD III, year 2010, Phase II summer)}

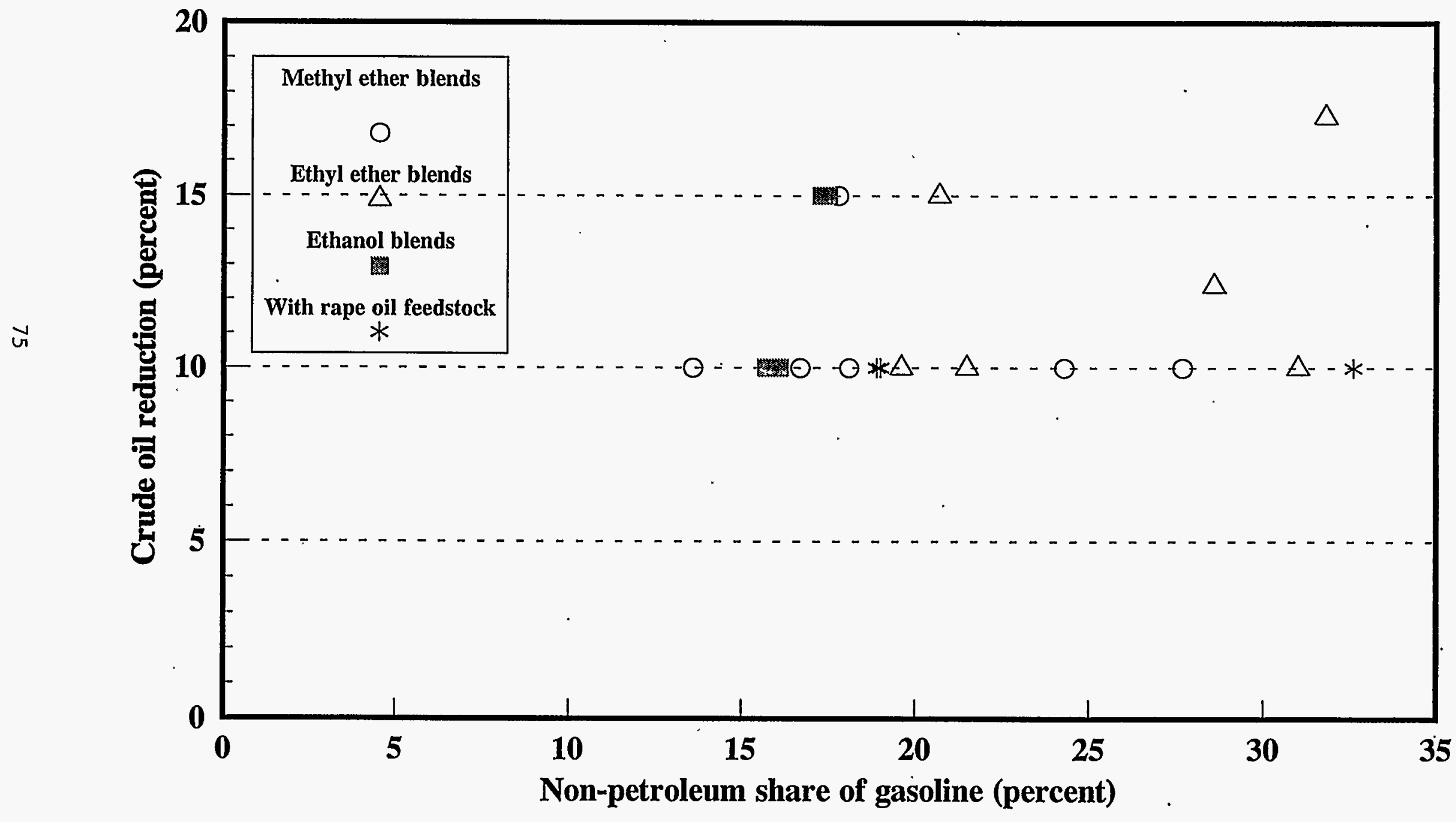




\section{Fig. 15. Crude oil use reduction in low petroleum gasoline cases \\ PADD III, year 2010, Phase II summer}

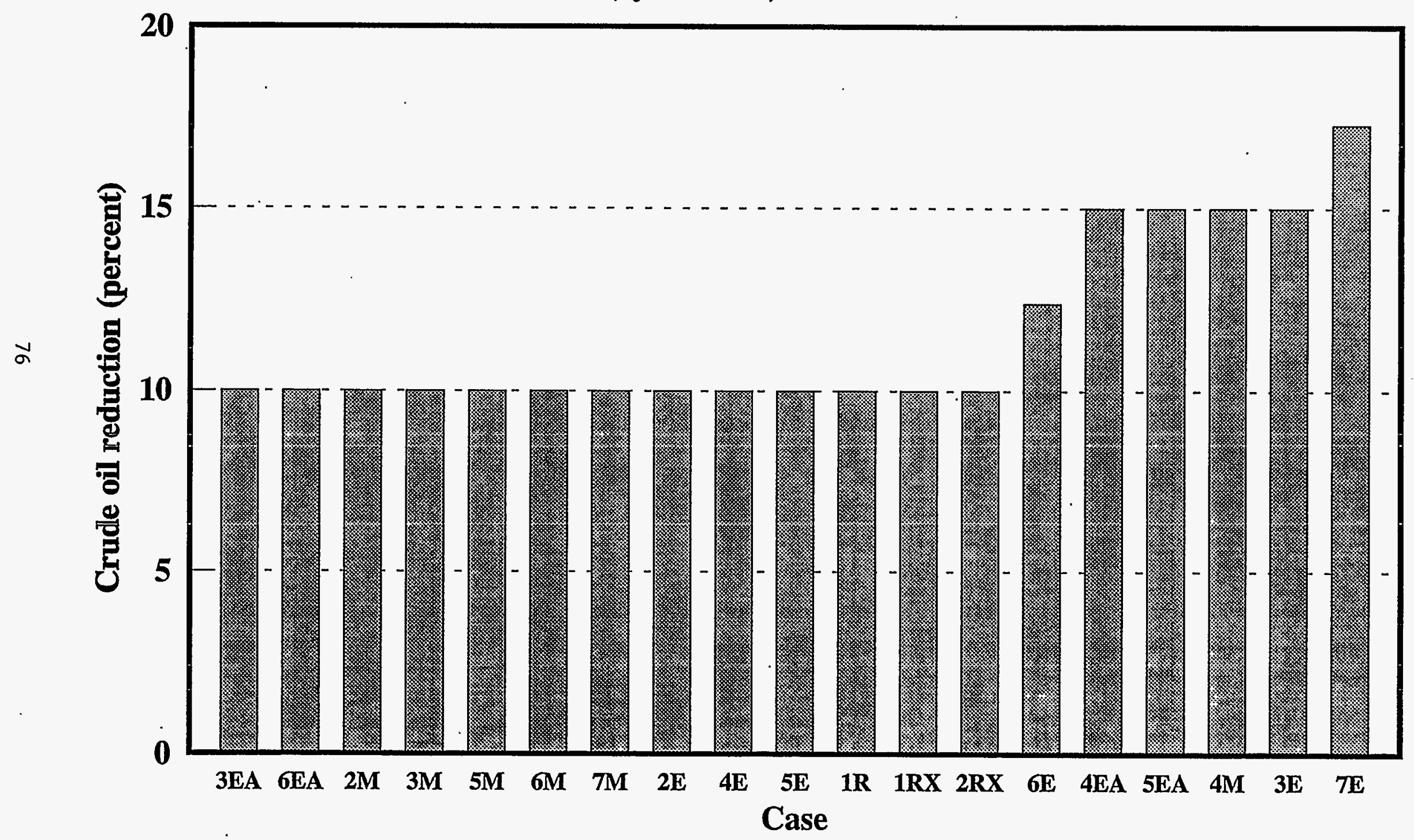




\section{Fig. 16. Low petroleum refinery fuel use \\ (PADD III, year 2010, Phase II summer)}

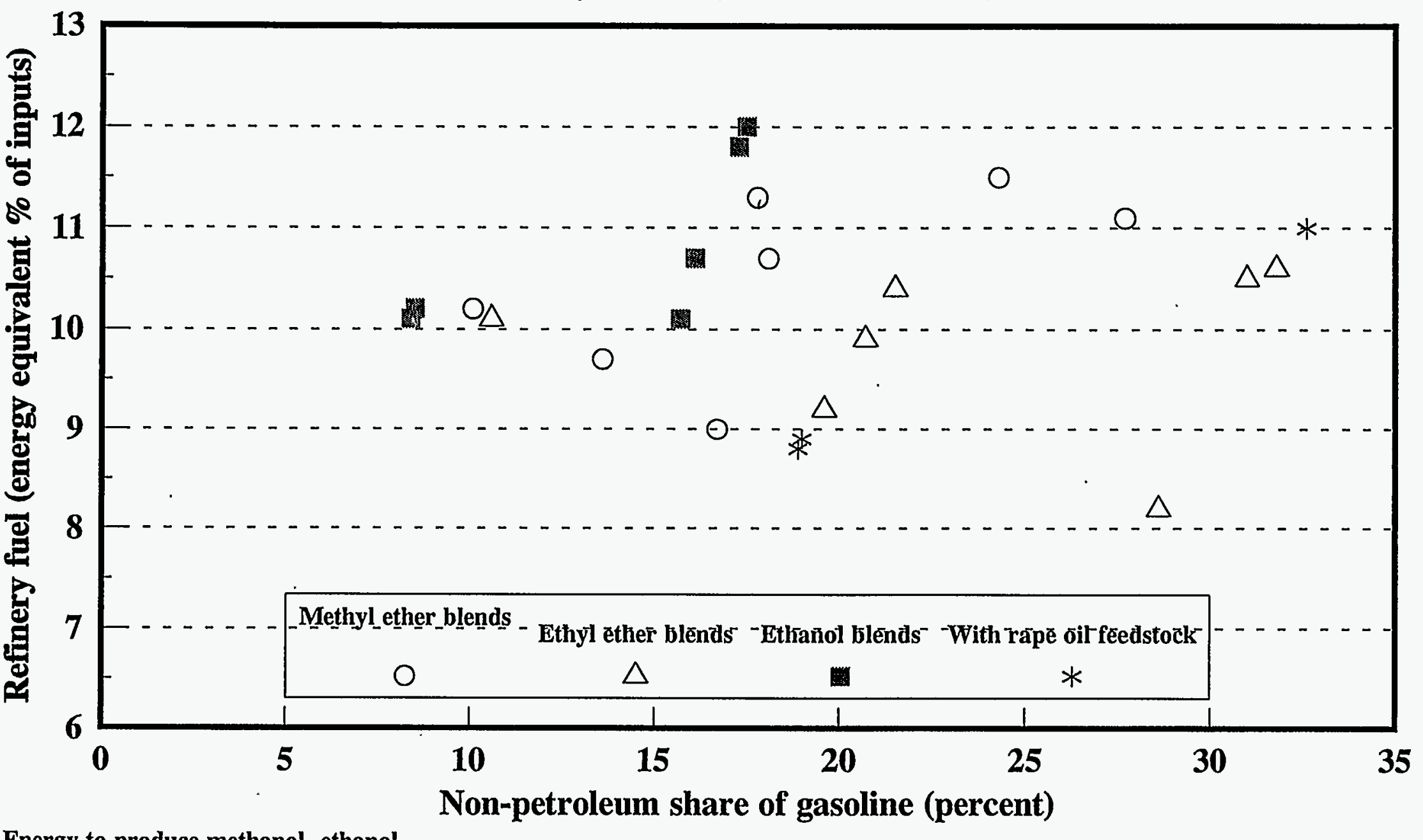

Energy to produce methanol, ethanol, rapeseed oil, and purchased ethers not included in inputs. 


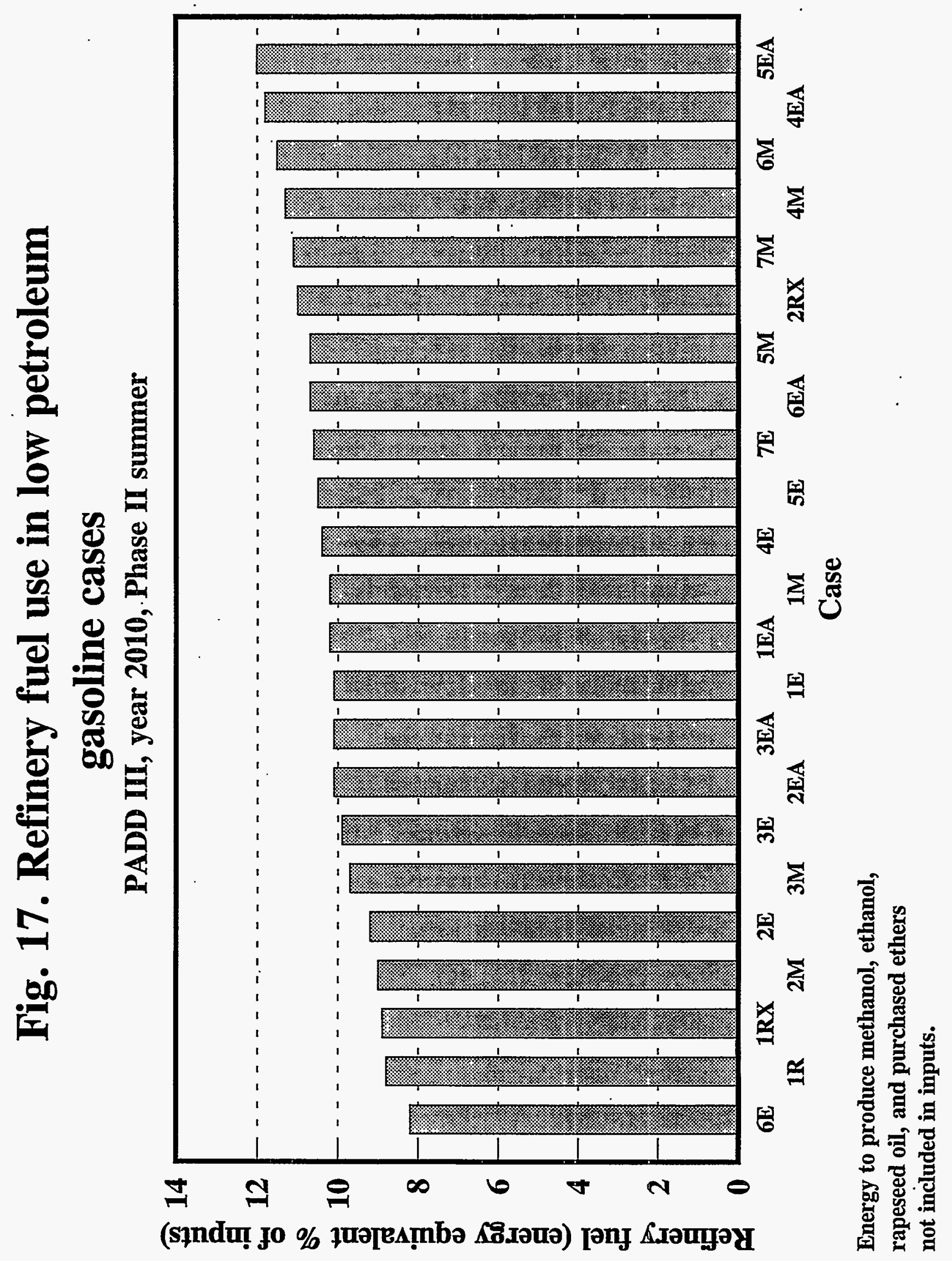


Fig. 18. Refinery investment for low petroleum gasoline policy

(PADD III, year 2010, Phase II summer)

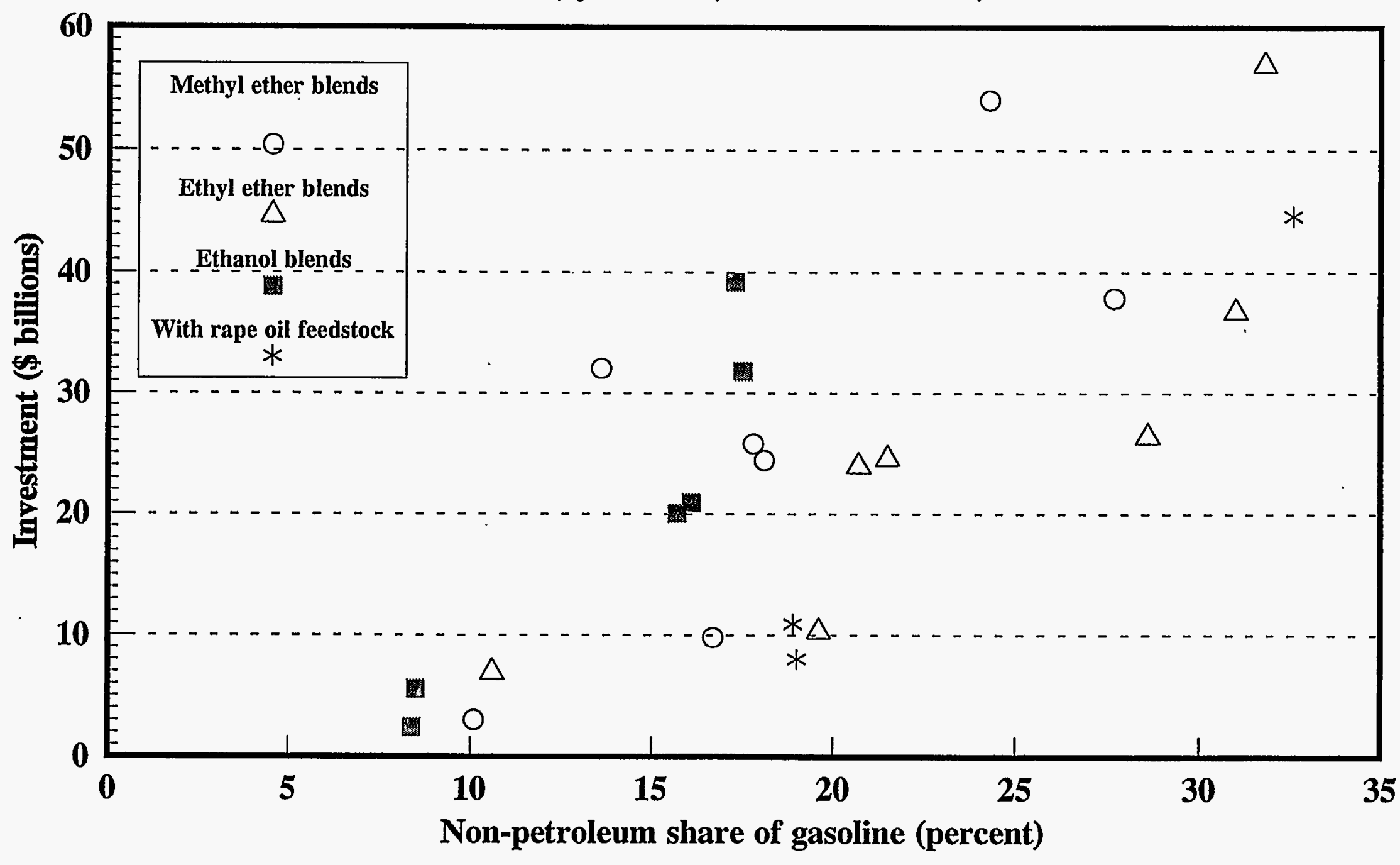


Fig. 19. Refinery investment in low petroleum gasoline cases

PADD III, year 2010, Phase II summer

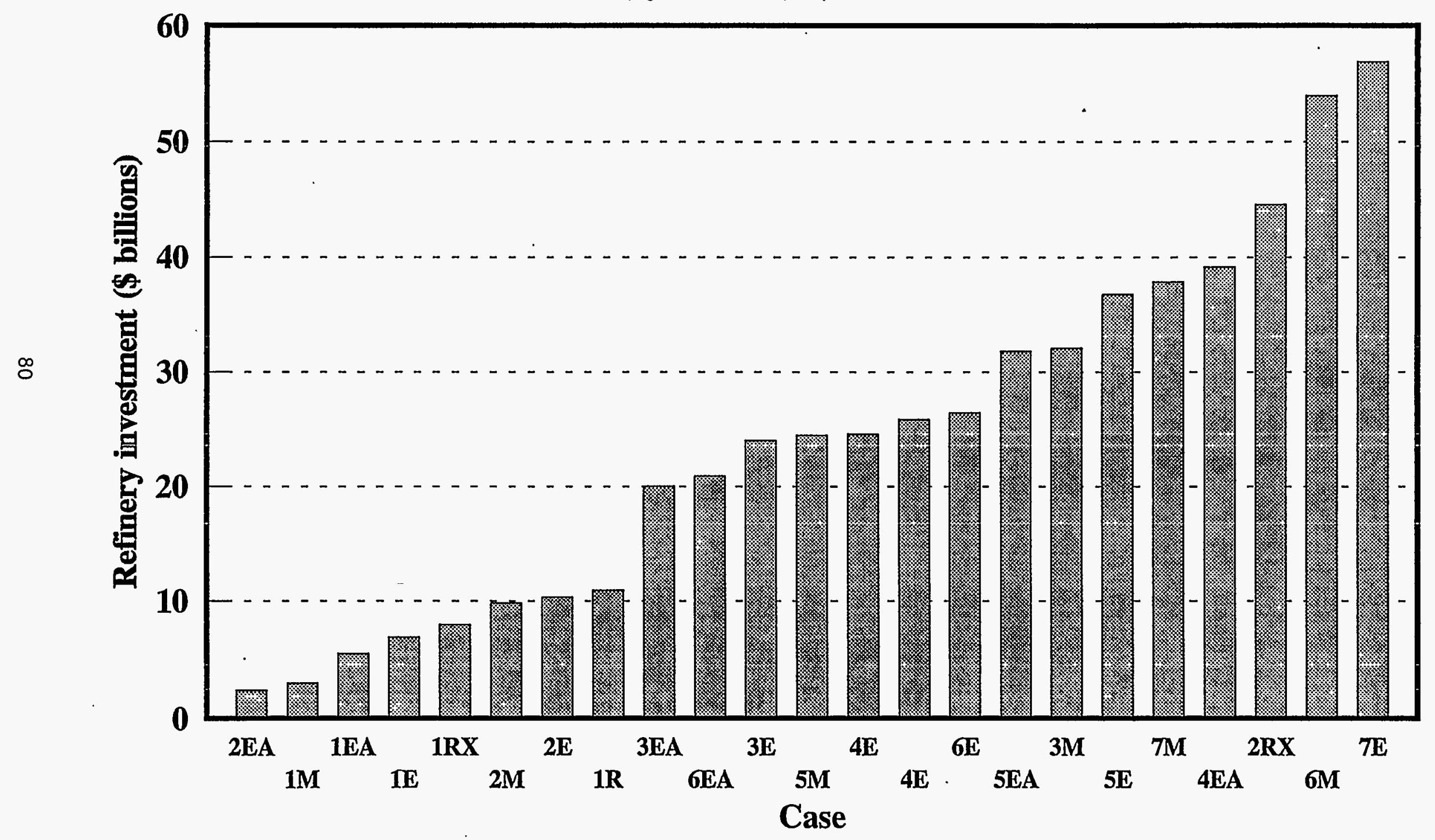




\section{Fig. 20. Greenhouse gas emissons for low petroleum gasoline}

PADD III, year 2010, Phase II summer and winter

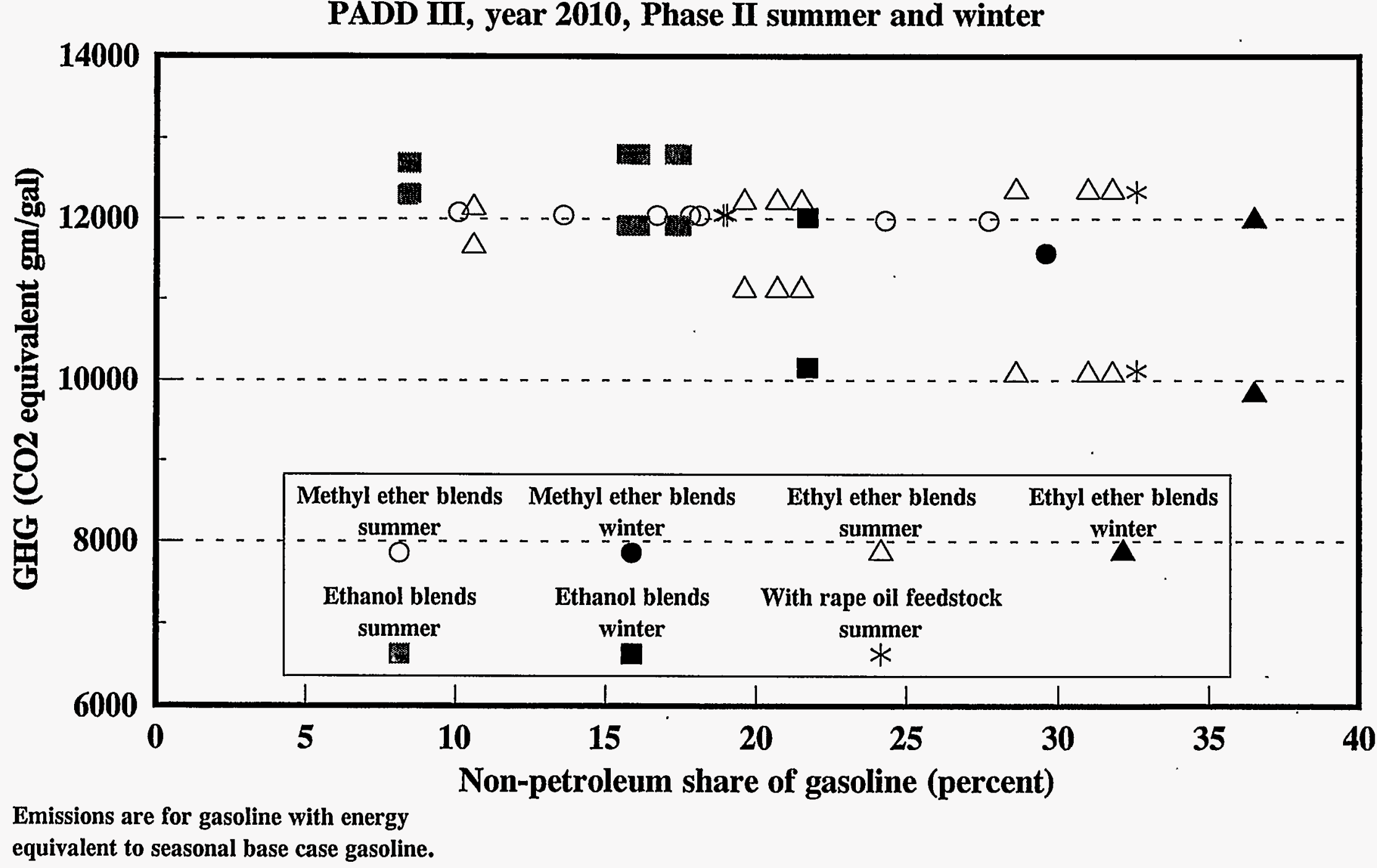




\section{Fig. 21. Greenhouse gas emissions for low petroleum gasolines relative to base gasolines \\ PADD III, year 2010, Phase II summer and winter}

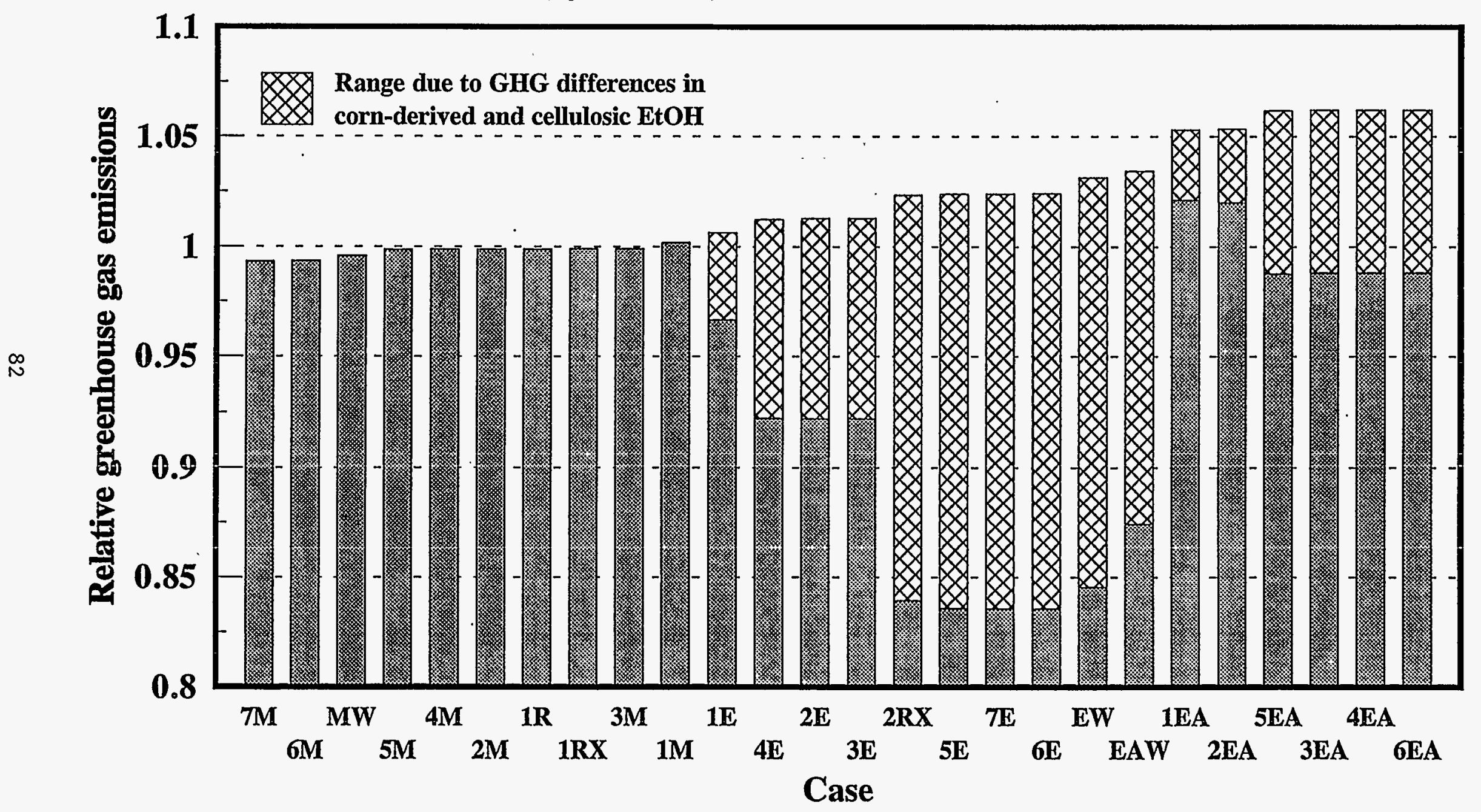

Emissions are for gasoline with energy equivalent to seasonal base case gasoline. 
Fig. 22. Cost increases for low petroleum gasoline, CG RVP max $=8.7$ psi (elastic prices)

PADD III, year 2010, Phase II summer

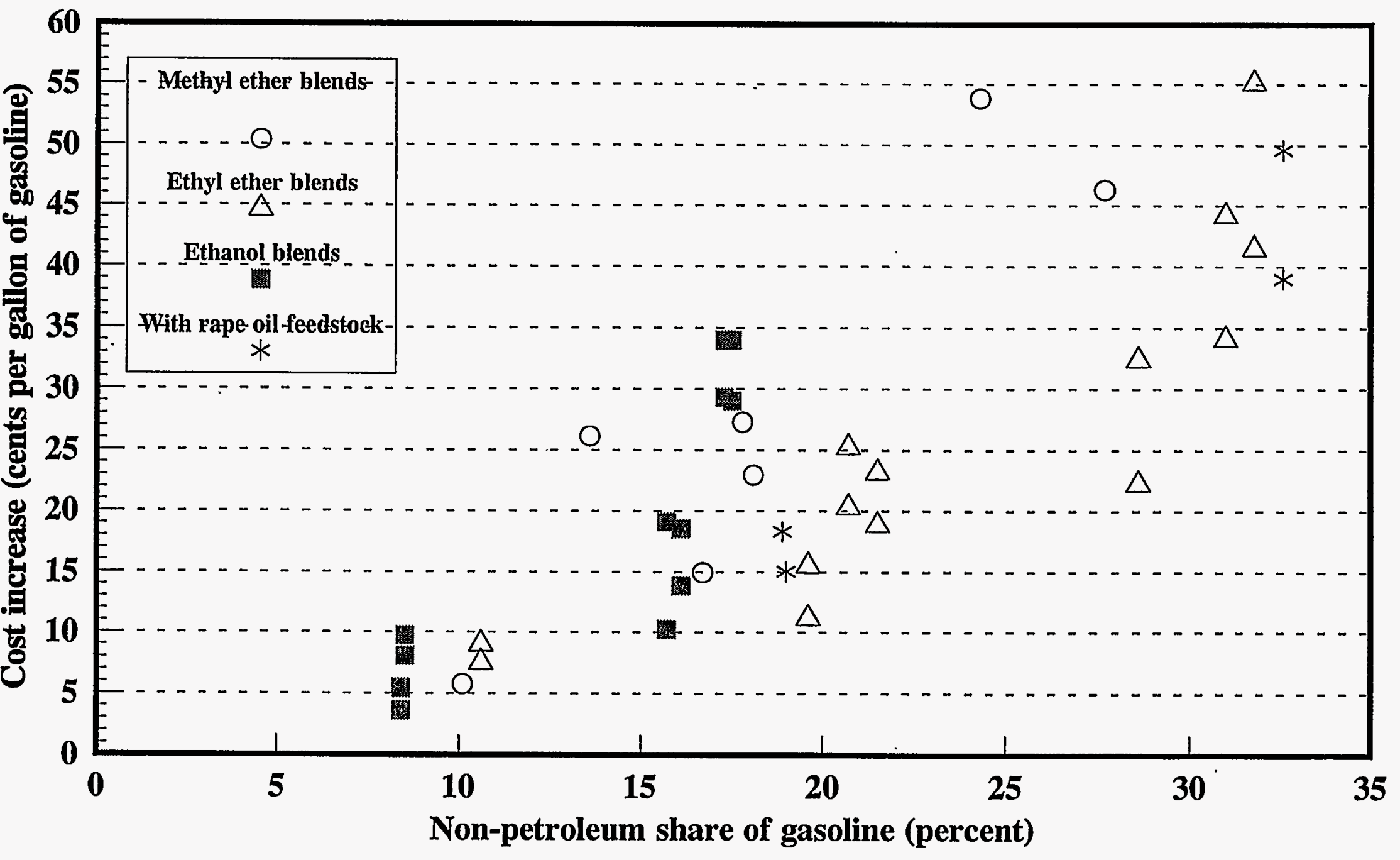




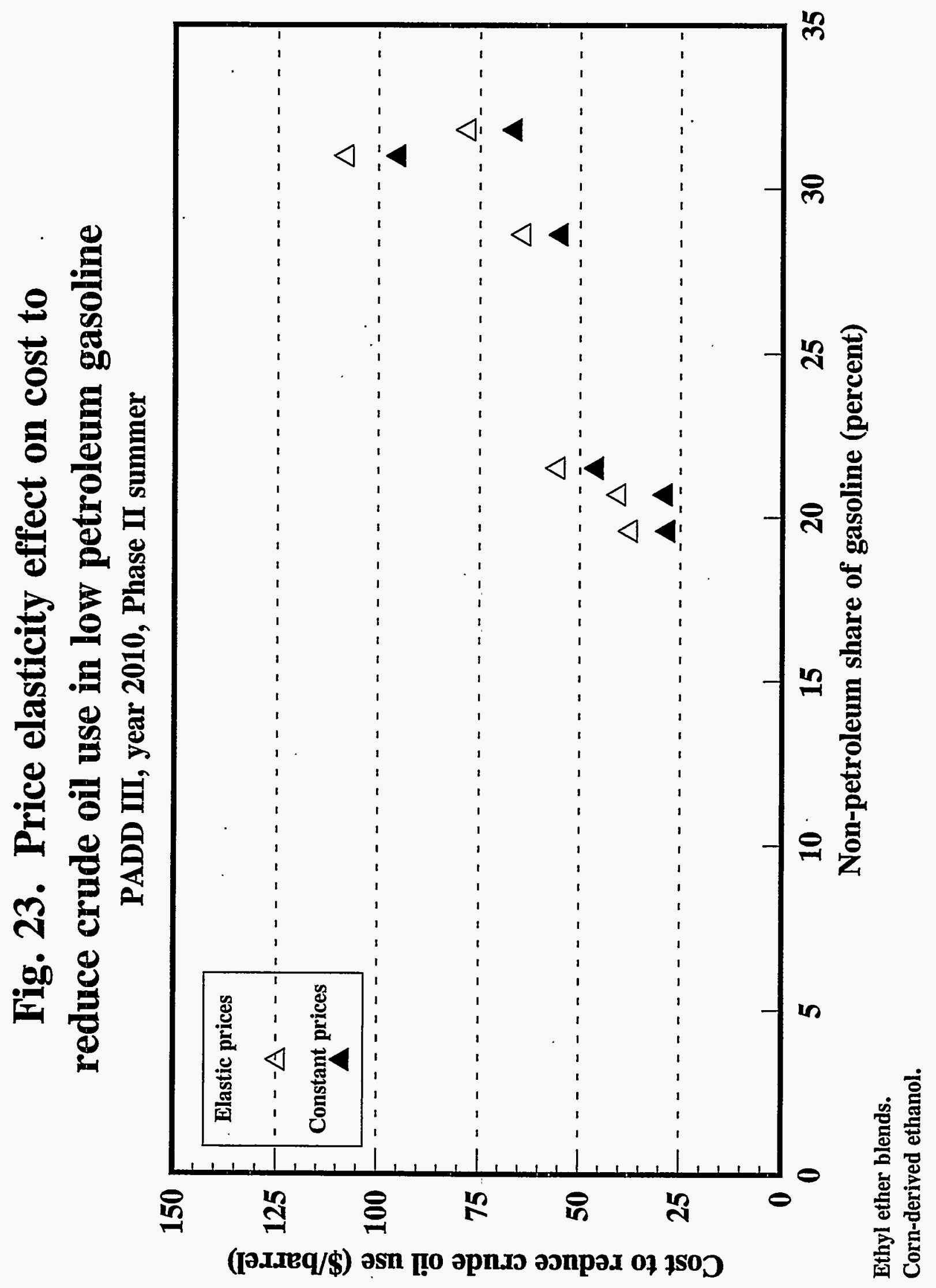




\section{Fig. 24. Year-round refining cost increase for near-30 percent non-petroleum in gasoline}

PADD III, year 2010

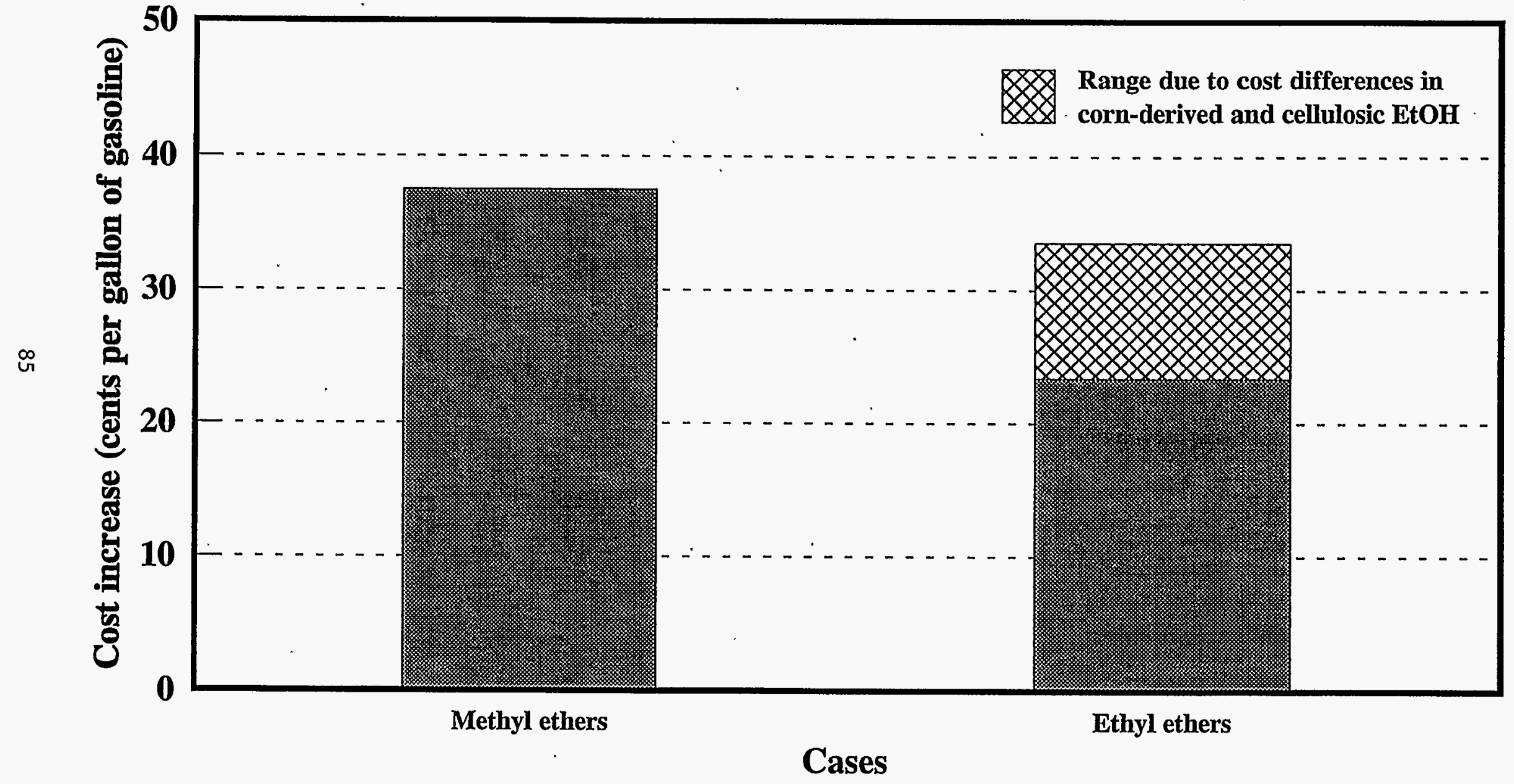

6.5 month winter season.

Methyl ethers: cases $7 \mathrm{M}$ and MW (29\% non-pet).

Ethyl ethers: cases 5E and EW (34\% non-pet). 


\section{Fig. 25. Year-round cost to reduce crude oil use for near-30 percent non-petroleum in gasoline}

PADD III, year 2010

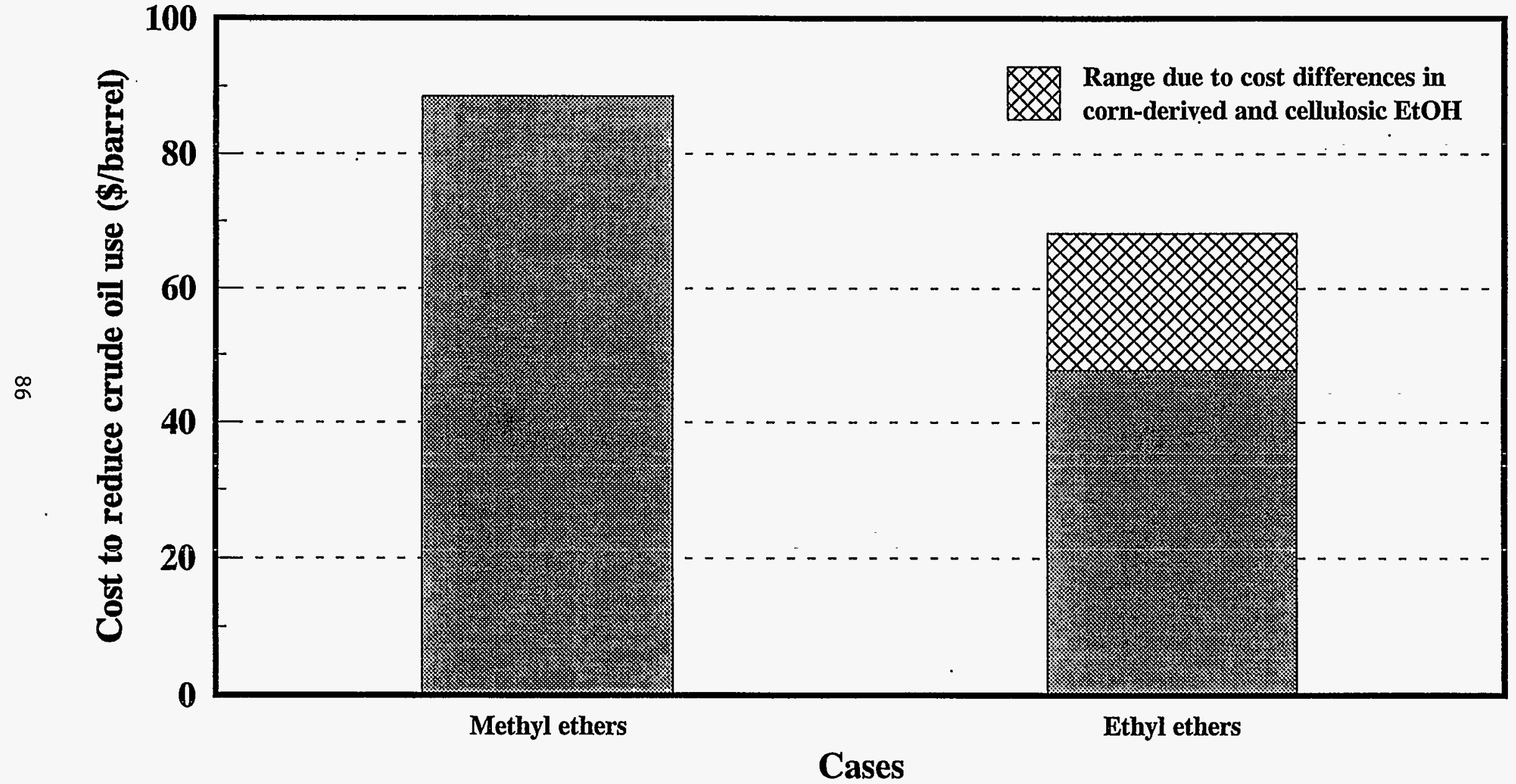

6.5 month winter season.

Methyl ethers: cases $7 \mathrm{M}$ and MW (29\% non-pet).

Ethyl ethers: cases 5E and EW (34\% non-pet). 


\section{Fig. 26. Year-round relative greenhouse gases for near-30 percent non-petroleum in gasoline}

PADD III, year 2010

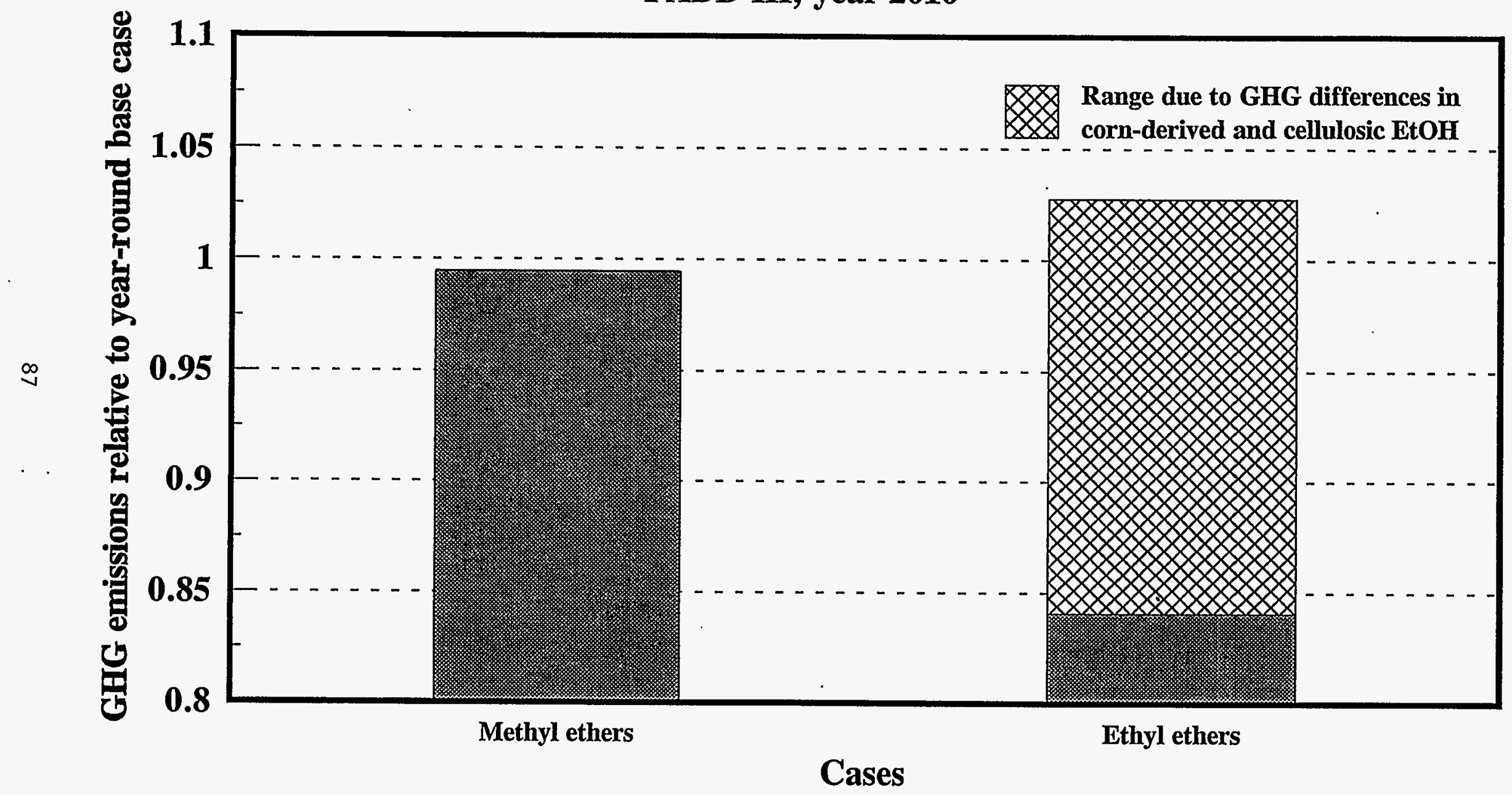

6.5 month winter season.

Methyl ethers: cases 7M and MW (29\% non-pet).

Ethyl ethers: cases 5E and EW (34\% non-pet). 
APPENDIX A

RAW MATERIAL SUPPLY CURVE ESTIMATION 
The crude oil supply curve for PADD III (Fig. 1)

The crude oil supply base is assumed to be global, at $60,000 \mathrm{MBD}$. The projected world reference price for crude oil in the year 2010 is $\$ 26.49 /$ barrel (1990 dollars).

The crude oil supply elasticity is assumed to be 0.3 . Assume that

$$
\ln (\mathrm{Q})=\text { elasticity } * \ln (\mathrm{P})+\mathrm{C} \text {, where } \mathrm{Q} \text { is global supply and } \mathrm{P} \text { is the world reference price. }
$$

Then,

$$
\begin{aligned}
& \ln (60000)=.3 * \ln (26.49)+C \\
& \text { and } C=10.019 .
\end{aligned}
$$

The desired supply curve is for PADD III refineries. The assumed reference supply conditions are Q3 $=6070 \mathrm{MBD}$ for PADD III refineries. Assume the low petroleum program effects in PADD III refineries are proportional to effects in all other PADDs. The reference supply condition for refineries in all PADDs is $13411 \mathrm{MBD}$. To scale the crude effect from PADD III to refineries in all PADDs, use $\mathrm{Q} 3 * 13411 / 6070=2.209 * \mathrm{Q} 3$.

Let $Q=$ crude supply for non-US refinery uses + supply for US refinery uses. Then

$$
\begin{aligned}
& \mathrm{Q}=(60000-13411)+2.209 * \mathrm{Q} 3 . \\
& \mathrm{Q}=46589+2.209 * \mathrm{Q} 3 .
\end{aligned}
$$

The PADD III crude slate for year 2010 is relatively heavy, high sulfur crude, with a weighted reference price of P3 $=\$ 25.16 / \mathrm{barrel}$. Then, the reference price for world oil is P3 $+\$ 1.33$, and the supply curve becomes

$$
\ln (46589+2.209 * \mathrm{Q} 3)=.3 * \ln (\mathrm{P} 3+1.33)+10.019
$$


The natural gas supply curve for PADD III (Fig. 2)

The natural gas supply base supply base for the US is assumed to be the US, Canada, and Mexico.

Assume that US consumption is 85 percent of supply. Therefore the supply $\mathrm{Q}=66301 \mathrm{MMSCFD} / .85$ $=78001 \mathrm{MMSCFD}$. The year 2010 reference price for dry natural gas is assumed to be $\$ 3.17 / \mathrm{MCF}$, derived from raw material price relationships reported by the National Petroleum Council.

The natural gas supply elasticity is assumed to be 0.3 . Assume that

$$
\ln (\mathrm{Q})=\text { elasticity* } \ln (\mathrm{P})+\mathrm{C} \text {, where } \mathrm{Q} \text { is supply and } \mathrm{P} \text { is the reference price for dry natural gas. }
$$

Then,

$$
\begin{aligned}
& \ln (78001)=.3 * \ln (3.17)+C, \\
& \text { and } C=10.918
\end{aligned}
$$

The desired supply curve is for PADD III refineries. Assume the reference supply conditions are $\mathrm{Q} 3=$ 1317 MMSCFD for PADD III refineries. Assume the low petroleum program effects in PADD III refineries are proportional to effects in all other PADDs. The reference supply condition for refineries in all PADDs is $1935 \mathrm{MMSCFD}$. To scale the natural gas effect from PADD III to refineries in all $\mathrm{PADDs}$, use Q3*1935/1317 = $1.47 * \mathrm{Q} 3$.

Let $Q=$ supply for non-refinery uses + supply for refinery uses. Then

$$
\begin{aligned}
& \mathrm{Q}=(78001-1935)+1.47 * \mathrm{Q} 3 \\
& \mathrm{Q}=76066+1.47 * \mathrm{Q} 3
\end{aligned}
$$

The price $\mathrm{P} 3$ of gas to PADD III refineries is the dry gas reference price $\mathrm{P}$, with a regional refinery price adjustment of $+\$ 0.437 / \mathrm{MCF}$. Then, the reference price is $\mathrm{P}=\mathrm{P} 3+\$ .437 / \mathrm{MCF}$, and the supply curve becomes

$$
\ln (76066+1.47 * \mathrm{Q} 3)=.3 * \ln (\mathrm{P} 3-0.437)+10.918 .
$$

\section{The corn-derived ethanol supply curve for PADD III (Fig. 3)}

The feedstock component of the price for corn-derived fuel ethanol is reported in "Estimation of Supply Curve for Ethanol with Corn as the Feedstock." In this report, the average elasticity for the year 2005 and 2015 ethanol feedstock curves is 4.35 . Assume in the base case that the feedstock component is $\$ 0.30 /$ gallon or $\$ 12.6 / \mathrm{barrel}$. Assume that the base price of ethanol, with credit for the federal subsidy, is $\$ 29.98$ per barrel. Assume in the base case, 80 percent of ethanol production capacity is used $=72$ MBD.

Assume that only the feedstock component is price sensitive. Assume that 


$$
\ln (Q)=\text { elasticity } * \ln (P)+C \text {, where } Q \text { is supply and } P \text { is the price. }
$$

Then,

$$
\ln (72)=4.35 * \ln (12.6)+C
$$

and $\mathrm{C}=-6.7449$

Assume regional supply of fuel ethanol is proportional to regional gasoline production. Then $\mathrm{Q}=$ $2.25^{*} \mathrm{Q} 3$, where $\mathrm{Q} 3$ is supply of fuel ethanol for PADD III. The fuel ethanol price P3 includes the nonfeedstock price component, so the feedstock price $=$ P3 - 17.38. The supply curve becomes

$$
\ln (2.25 * \mathrm{Q} 3)=4.35 * \ln (\mathrm{P} 3-17.38)-6.7449 \text {. }
$$

\section{The supply curve for cellulosic ethanol}

The price of cellulosic ethanol is the sum of (1) the feedstock cost from the nearly flat supply curve presented in Figure 2-6 of reference 51, (2) the cost of manufacturing conversion from the same report, with (3) credit for the federal subsidy. Over the range of cases in the low petroleum study, the cellulosic ethanol price is in the range of $\$ 16.24$ to $\$ 16.88$ per barrel. 


\begin{abstract}
APPENDIX B
BLENDSTOCKS, PROPERTIES, PROCESS INVESTMENTS, AND FUEL USE FOR SUMMER GASOLINE PRODUCTION
\end{abstract}




\begin{tabular}{||l||c||}
\hline \multicolumn{2}{|c|}{$\begin{array}{c}\text { Table B-1. } \\
\text { 2010 summer }\end{array}$} \\
PADD III base case blendstocks for year \\
\hline \multicolumn{1}{|c||}{ Blendstock } & Percent \\
\hline Butane & 1.7 \\
\hline Reformate & 30.4 \\
\hline Straight run naphtha & 1.2 \\
\hline C5+ isomerate & 2.9 \\
\hline FCC naphtha & 34.4 \\
\hline Coker naphtha & 1.4 \\
\hline Hydrocrackate & 7.1 \\
\hline Alkylate & 14.4 \\
\hline Polymer gasolines & 1.0 \\
\hline Dimate & 0.1 \\
\hline MTBE & 1.2 \\
\hline Toluene/xylene & 1.3 \\
\hline Natural gasoline & 0.8 \\
\hline Pyrolysis gasoline & 2.1 \\
\hline Raffinates & \\
\hline Other & 1.3 \\
\hline
\end{tabular}




\begin{tabular}{||l||c||}
\hline \multicolumn{1}{||c||}{$\begin{array}{c}\text { Table B-2. PADD III base case gasoline } \\
\text { properties for the year 2010 summer }\end{array}$} \\
\hline Octane, $(\mathrm{R}+\mathrm{M}) / 2$ & 88.7 \\
\hline RVP, psi & 7.9 \\
\hline Aromatics, vol\% & 32.4 \\
\hline Benzene, vol\% & 2.05 \\
\hline Olefins, vol\% & 11.4 \\
\hline Sulfur, ppm & 409 \\
\hline E200, \% & 46.0 \\
\hline E300, \% & 82.9 \\
\hline Specific gravity & .7434 \\
\hline Summer TAP, mg/mi & 87.1 \\
\hline NOx, mg/mi & 1378 \\
\hline VOC, mg/mi & 1270 \\
\hline GHG, CO ${ }_{2}$ equivalent gm/gal & 12053 \\
\hline
\end{tabular}




\begin{tabular}{|c|c|c|c|c|c|c|}
\hline \multicolumn{7}{|c|}{$\begin{array}{c}\text { Table B-3. } \\
\text { RFG blendstocks in PADD III for the year } 2010 \text { summer: } \\
\text { Ethanol blends } \\
\text { RFG minimum emissions reduction \%: VOC } 30 ; \text { summer TAP 26.5; NOx } 7.8 \\
\text { RFG production share }=62 \%\end{array}$} \\
\hline Case $\quad$ u & $\mathrm{BA}$ & $2 \mathrm{EA}$ & $3 \mathrm{EA}$ & $4 \mathrm{EA}$ & $5 \mathrm{AA}$ & $6 \mathrm{EA}$ \\
\hline RFG oxygen target, wt\% & 2.1 & 2.1 & 2.7 & 2.7 & 2.7 & 2.7 \\
\hline CG oxygen target, wt\% & & & 3.5 & 3.5 & 3.5 & 3.5 \\
\hline Crude reduction target, vol\% & & & 10 & 15 & 15 & 10 \\
\hline Forced hydrogenation? & No & No & No & No & No & Yes \\
\hline RFG VOC reduction, $\min \%$ & 30 & 24 & 30 & 30 & 30 & 30 \\
\hline CG RVP, $\max$ psi & 7.9 & 7.9 & 7.9 & 7.9 & 8.7 & 7.9 \\
\hline \multicolumn{7}{|l|}{ Blendstocks, vol\% } \\
\hline Butane & 1.5 & 1.5 & 1.5 & 1.5 & 1.5 & 1.5 \\
\hline Reformate & 35.8 & 26.7 & 36.0 & 33.8 & 34.8 & 37.4 \\
\hline Straight run naphtha & 2.0 & 2.4 & 0.9 & 0.6 & & 0.5 \\
\hline $\mathrm{C} 5+$ isomerate & 3.9 & 4.6 & 7.3 & 8.4 & 7.0 & 7.5 \\
\hline FCC naphtha & 7.9 & 21.2 & 0.6 & 1.7 & 1.7 & 1.4 \\
\hline \multicolumn{7}{|l|}{ Coker naphtha } \\
\hline Hydrocrackate & 10.0 & 7.8 & 8.4 & 10.1 & 13.6 & 10.2 \\
\hline Alkylate & 12.2 & 13.9 & 18.5 & 22.4 & 24.0 & 17.9 \\
\hline Polymer gasolines & 4.6 & 8.0 & 7.3 & 5.0 & 4.8 & 6.3 \\
\hline Dimate & 6.1 & 0.2 & 4.6 & 2.9 & & 2.1 \\
\hline Toluene/xylene & 4.4 & 4.0 & 0.3 & & & 0.3 \\
\hline \multicolumn{7}{|l|}{ Natural gasoline } \\
\hline \multicolumn{7}{|l|}{ Pyrolysis gasoline } \\
\hline Raffinates & 4.0 & 3.4 & 4.1 & 4.1 & 3.2 & 4.7 \\
\hline Other & 1.7 & 0.1 & 2.8 & 1.8 & 1.6 & 2.5 \\
\hline Ethanol & 6.0 & 6.1 & 7.8 & 7.8 & 7.8 & 7.8 \\
\hline
\end{tabular}




\begin{tabular}{|c|c|c|c|c|c|c|}
\hline \multicolumn{7}{|c|}{$\begin{array}{l}\text { Table B-4. } \\
\text { CG blendstocks in PADD III for the year } 2010 \text { summer: } \\
\text { Ethanol blends }\end{array}$} \\
\hline case & $1 \mathrm{EA}$ & $2 \mathrm{EA}$ & $3 \mathrm{EA}$ & $4 \mathrm{E} \mathrm{A}$ & 5EA: & $6 \mathrm{EA}$ \\
\hline RFG oxygen target, wt $\%$ & 2.1 & 2.1 & 2.7 & 2.7 & 2.7 & 2.7 \\
\hline CG oxygen target, wt\% & & & 3.5 & 3.5 & 3.5 & 3.5 \\
\hline Crude reduction target, vol\% & & & 10 & 15 & 15 & 10 \\
\hline Forced hydrogenation? & No & No & No & No & No & Yes \\
\hline RFG VOC reduction, min & 30 & 24 & 30 & 30 & 30 & 30 \\
\hline CG RVP, max psi & 7.9 & 7.9 & 7.9 & 7.9 & 8.7 & 7.9 \\
\hline Blendstocks, vol $\%$, & 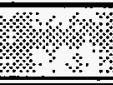 & : & & & ४ै। & 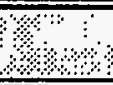 \\
\hline Butane & 1.5 & 1.5 & 1.5 & 1.5 & 1.5 & 1.5 \\
\hline Reformate & 22.2 & 24.7 & 25.6 & 29.9 & 30.8 & 25.6 \\
\hline Straight run naphtha & 2.3 & 3.2 & 10.5 & 8.4 & 9.4 & 10.5 \\
\hline $\mathrm{C} 5+$ isomerate & 3.2 & & & & & \\
\hline FCC naphtha & 43.2 & 43.5 & 24.9 & 17.4 & 17.9 & 24.9 \\
\hline Coker naphtha & & & & 2.0 & 2.0 & \\
\hline Hydrocrackate & & 8.3 & 13.4 & 17.9 & 13.0 & 13.4 \\
\hline Alkylate & 18.4 & 16.3 & 10.4 & 10.6 & 5.0 & 10.4 \\
\hline Polymer gasolines & & & 3.6 & 1.8 & 9.7 & 3.6 \\
\hline \multicolumn{7}{|l|}{ Dimate } \\
\hline Toluene/xylene & & & & 0.4 & 0.6 & \\
\hline \multicolumn{7}{|l|}{ Natural gasoline } \\
\hline \multicolumn{7}{|l|}{ Pyrolysis gasoline } \\
\hline Raffinates & 2.5 & 1.8 & & & & \\
\hline Other & 6.8 & & & & . & \\
\hline Ethanol & & 0.6 & 10.1 & 10.1 & 10.1 & 10.1 \\
\hline
\end{tabular}




\begin{tabular}{|c|c|c|c|c|c|c|}
\hline \multicolumn{7}{|c|}{$\begin{array}{l}\text { Table B-5. } \\
\text { PADD II RFG properties for the year } 2010 \text { summer: } \\
\text { Ethanol blends } \\
\text { RFG minimum emissions reduction \%: VOC } 30 ; \text { summer TAP } 26.5 ; \text { NOx } 7.8 \\
\text { RFG production share }=62 \%\end{array}$} \\
\hline Case & IEA & $2 \mathrm{EA}$ & $3 \mathrm{EA}$ & 4EA & $5 \mathrm{EA}$ & $6 \mathrm{EA}$ \\
\hline RFG oxygen target, wt\% & 2.1 & 2.1 & 2.7 & 2.7 & 2.7 & 2.7 \\
\hline CG oxygen target, wt\% & & & 3.5 & 3.5 & 3.5 & 3.5 \\
\hline Crude reduction target, vol\% & & & 10 & 15 & 15 & 10 \\
\hline Forced hydrogenation? & No & No & No & No & No & Yes \\
\hline RFG VOC reduction, $\min \%$ & 30 & 24 & 30 & 30 & 30 & 30 \\
\hline CG RVP, max psi & 7.9 & 7.9 & 7.9 & 7.9 & 8.7 & 7.9 \\
\hline Properties $\therefore$ a : a & औे & & \& & & + & 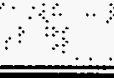 \\
\hline Octane, $(\mathrm{R}+\mathrm{M}) / 2$ & 89.0 & 88.8 & 89.2 & 89.5 & 89.6 & 89.3 \\
\hline RVP, psi & 6.8 & 7.4 & 6.9 & 6.8 & 6.8 & 6.8 \\
\hline Aromatics, vol\% & 27.9 & 26.7 & 22.6 & 21.8 & 21.0 & 23.9 \\
\hline Benzene, vol\% & 0.90 & 0.90 & 0.90 & 0.90 & 0.90 & 0.90 \\
\hline Olefins, vol\% & 14.9 & 12.3 & 14.9 & 10.3 & 7.0 & 11.4 \\
\hline Sulfur, ppm & 56 & 96 & 43 & 44 & 44 & 45 \\
\hline $\mathrm{E} 200, \%$ & 49.9 & 49.9 & 49.9 & 49.9 & 49.9 & 49.9 \\
\hline $\mathrm{E} 300, \%$ & 88.6 & 87.5 & 89.3 & 89.3 & 89.5 & 89.3 \\
\hline Oxygen, wt\% & 2.21 & $2: 24$ & 2.73 & 2.89 & 2.90 & 2.87 \\
\hline Specific gravity & .7538 & .7464 & .7447 & .7425 & .7423 & .7470 \\
\hline Summer TAP, mg/mi & 57.6 & 57.8 & 58.2 & 54.0 & 53.5 & 55.0 \\
\hline $\mathrm{NOx}, \mathrm{mg} / \mathrm{mi}$ & 1234 & $\underline{1236}^{\mathrm{a}}$ & 1235 & 1170 & 1153 & 1185 \\
\hline $\mathrm{VOC}, \mathrm{mg} / \mathrm{mi}$ & $\underline{1006}$ & $\underline{1093}$ & 1008 & $\underline{1006}$ & $\underline{1007}$ & $\underline{1005}$ \\
\hline \multirow{2}{*}{$\begin{array}{l}\mathrm{GHG}, \mathrm{CO}_{2} \text { equivalent gm/gal } \\
\text { (energy equivalent to base case } \\
\text { gasoline) }\end{array}$} & $13084^{b}$ & 13083 & 13115 & 13115 & 13112 & 13115 \\
\hline & $12459^{\circ}$ & 12456 & 12307 & 12307 & 12307 & 12307 \\
\hline \multicolumn{7}{|c|}{$\begin{array}{l}\text { aUnderlined emissions are binding constraints } \\
\text { bEntry above dashed line is for corn-derived ethanol } \\
\text { "Entry below dashed line is for cellulosic ethanol }\end{array}$} \\
\hline
\end{tabular}




\begin{tabular}{|c|c|c|c|c|c|c|}
\hline \multicolumn{7}{|c|}{$\begin{array}{c}\text { Table B-6. } \\
\text { PADD III CG properties for the year } 2010 \text { summer: } \\
\text { Ethanol blends }\end{array}$} \\
\hline 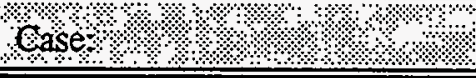 & $1: \mathrm{AA}$ & $2 \mathrm{E} A$ & $3 \mathrm{EA}+$ & $4 \mathrm{EA}$ & $\mathrm{SEA}$ & $6 \mathrm{EA}$ \\
\hline RFG oxygen target, wt\% & 2.1 & $2: 1$ & 2.7 & 2.7 & 2.7 & 2.7 \\
\hline CG oxygen target, wt\% & & & 3.5 & 3.5 & 3.5 & 3.5 \\
\hline Crude reduction target, vol\% & & & 10 & 15 & 15 & 10 \\
\hline Forced hydrogenation? & No & No & No & No & No & Yes \\
\hline RFG VOC reduction, $\min \%$ & 30 & 24 & 30 & 30 & 30 & 30 \\
\hline CG RVP, max psi & 7.9 & 7.9 & 7.9 & 7.9 & 8.7 & 7.9 \\
\hline Properties & ..?. & & ২. & $4 \%$ & 4. & \& \\
\hline Octane, $(R+M) / 2$ & 88.6 & 88.6 & 88.6 & 89.0 & 88.6 & 88.6 \\
\hline RVP, psi & 7.9 & 7.9 & 7.9 & 7.9 & 8.7 & 7.9 \\
\hline Aromatics, vol\% & 32.8 & 32.7 & 32.7 & 32.4 & 31.8 & 32.8 \\
\hline Benzene, vol\% & 1.60 & 1.60 & 1.50 、 & 1.51 & 2.08 & 1.55 \\
\hline Olefins, vol\% & 8.2 & 9.1 & 7.6 & 5.1 & 13.6 & 7.9 \\
\hline Sulfur, ppm & 360 & 356 & 337 & 177 & 199 & 230 \\
\hline $\mathrm{E} 200, \%$ & 47.0 & 43.1 & 49.9 & 49.9 & .49 .9 & 49.9 \\
\hline $\mathrm{E} 300, \%$ & 81.6 & 81.3 & 88.2 & 89.0 & 89.0 & 88.6 \\
\hline Oxygen, wt\% & 0.00 & 0.23 & 3.66 & 3.66 & 3.68 & 3.66 \\
\hline Specific gravity & .7422 & .7440 & .7587 & .7587 & .7574 & .7587 \\
\hline Summer TAP, mg/mi & $79.1^{2}$ & $\underline{79.1}$ & 73.5 & 69.5 & $\underline{79.1}$ & 71.6 \\
\hline NOx, mg/mi & $\underline{1348}$ & 1346 & 1333 & 1259 & 1317 & 1292 \\
\hline $\mathrm{VOC}, \mathrm{mg} / \mathrm{mi}$ & 1277 & 1290 & 1221 & 1199 & 1337 & 1202 \\
\hline \multirow{2}{*}{$\begin{array}{l}\mathrm{GHG}, \mathrm{CO}_{2} \text { equivalent gm/gal } \\
\text { (energy equivalent to base case } \\
\text { gasoline) }\end{array}$} & \multirow[t]{2}{*}{12060} & $12072^{b}$ & 12301 & 12301 & 12296 & 12301 \\
\hline & & $12032^{c}$ & 11269 & 11269 & 11262 & 11269 \\
\hline \multicolumn{7}{|c|}{$\begin{array}{l}\text { aUnderlined emissions are binding constraints } \\
\text { 'Entry above dashed line is for corn-derived ethanol } \\
\text { 'Entry below dashed line is for cellulosic ethanol }\end{array}$} \\
\hline
\end{tabular}




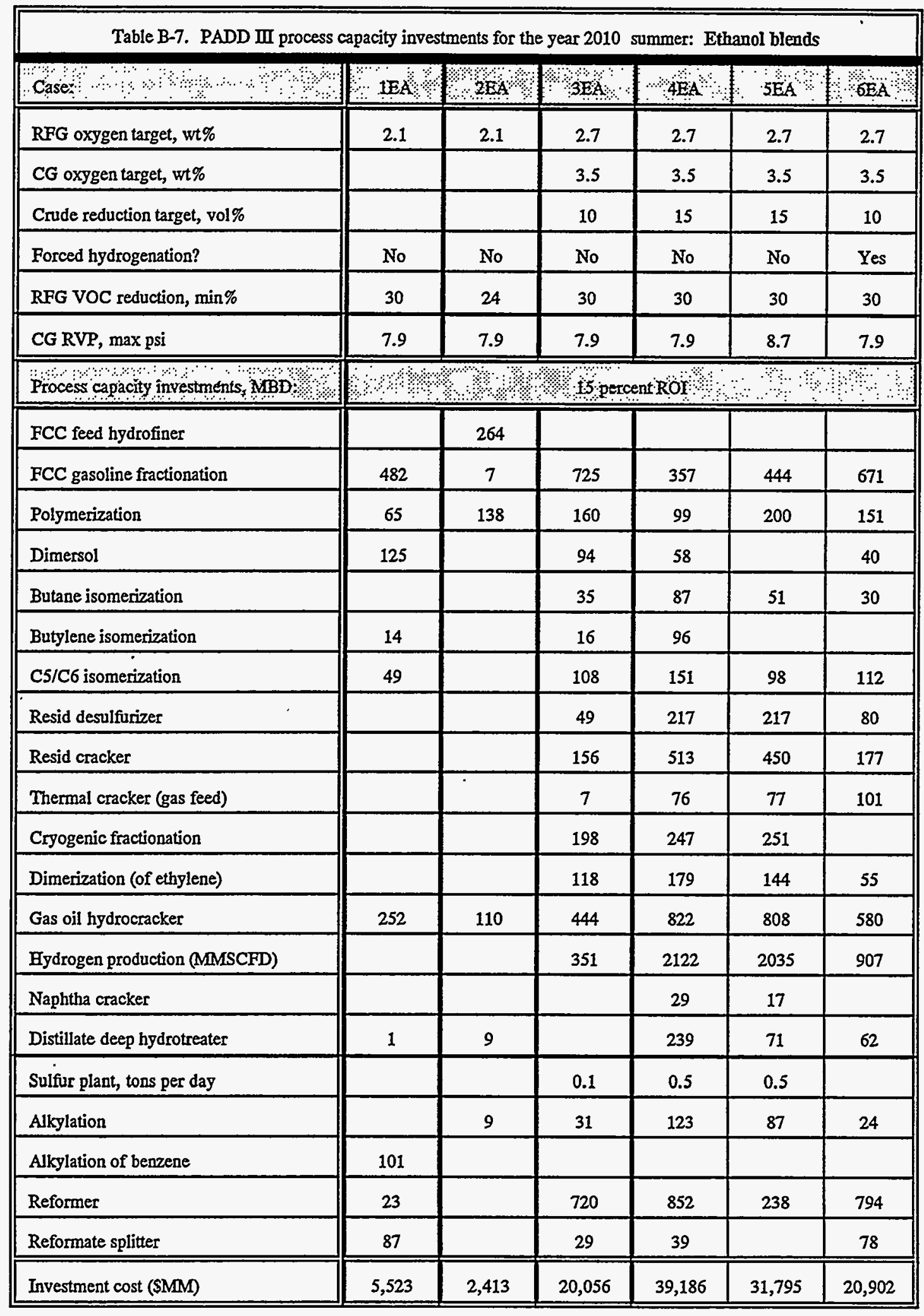


Table B-8. PADD III low petroleum refinery fuel use for the year 2010 summer: Ethanol blends

\begin{tabular}{|c|c|c|c|c|c|c|c|}
\hline ouse $.4 \%$ \%) & Base & Hel & $2 \mathrm{EA}$ & $3 \mathrm{EA}$ & $4 \mathrm{EA}$ & $5 \mathrm{EA}$ & $6 \mathrm{GEA}$ \\
\hline RFG oxygen target, wt\% & & 2.1 & 2.1 & 2.7 & 2.7 & 2.7 & 2.7 \\
\hline CG oxygen target, wt\% & & & & 3.5 & 3.5 & 3.5 & 3.5 \\
\hline $\begin{array}{l}\text { Crude reduction target, } \\
\text { vol\%. }\end{array}$ & & & & 10 & 15 & 15 & 10 \\
\hline Forced hydrogenation? & & No & No & No & No & No & Yes \\
\hline RFG VOC reduction, $\min \%$ & & 30 & 24 & 30 & 30 & 30 & 30 \\
\hline CG RVP, max psi & & 30 & 24 & 30 & 30 & 8.7 & 7.9 \\
\hline Refinery fill, energy $/ 4$ & & 10.2 & 10. & 1018 & 1108 & 12,0 & 101 \\
\hline
\end{tabular}




\begin{tabular}{|c|c|c|c|c|c|c|}
\hline \multicolumn{7}{|c|}{$\begin{array}{l}\text { Table B-9. } \\
\text { RFG blendstocks in PADD III for the year } 2010 \text { summer: } \\
\text { Methyl ether oxygenates } \\
\text { RFG minimum emissions reduction \%: VOC } 30 ; \text { summer TAP } 26.5 ; \text { NOx } 7.8 \\
\text { RFG production share }=62 \%\end{array}$} \\
\hline Casero on on wo & $1 \mathrm{M}$ & $2 M$ & $3 M$ & $41 \mathrm{x}$ & $5 \mathrm{MI}$ & $6 \mathrm{M}$ \\
\hline RFG oxygen target, wt $\%$ & 2.1 & $2: 7$ & 2.7 & 2.7 & 2.7 & 6.0 \\
\hline CG oxygen target, wt\% & & 3.5 & 3.5 & 3.5 & 3.5 & 6.0 \\
\hline Crude reduction target, vol\% & & 10 & 10 & 15 & 10 & 10 \\
\hline $\begin{array}{l}\text { Oxygenate imports allowed, } \\
\text { vol\% }\end{array}$ & 43 & 43 & 0 & 43 & 43 . & 43 \\
\hline Forced hydrogenation? & No & No & No & No & Yes & No \\
\hline \multicolumn{7}{|l|}{ Blendstocks, vol \%: } \\
\hline Butane & 1.5 & 1.5 & 1.5 & 1.5 & 1.5 & 1.5 \\
\hline Reformate & 26.9 & 21.3 & 26.0 & 24.6 & 25.0 & 18.9 \\
\hline Straight run naphtha & 0.6 & 3.9 & & 6.7 & 0.5 & \\
\hline $\mathrm{C} 5+$ isomerate & 6.9 & 8.3 & & 6.4 & 9.1 & 2.8 \\
\hline FCC naphtha & 25.9 & 24.0 & 20.4 & 10.9 & 18.2 & 1.2 \\
\hline \multicolumn{7}{|l|}{ Coker naphtha } \\
\hline Hydrocrackate & 6.3 & 5.5 & 10.9 & & 10.3 & \\
\hline Alkylate & 11.4 & 8.7 & 11.6 & 19.8 & 13.3 & \\
\hline Polymer gasolines & 2.5 & 7.3 & 10.1 & 9.4 & 3.3 & 19.9 \\
\hline Dimate & 1.3 & & & & & \\
\hline Toluene/xylene & 0.3 & 0.3 & 0.2 & 0.4 & 0.3 & 6.5 \\
\hline \multicolumn{7}{|l|}{ Natural gasoline } \\
\hline \multicolumn{7}{|l|}{ Pyrolysis gasoline } \\
\hline Raffinates & 3.4 & 3.2 & 3.2 & 3.2 & 2.6 & 15.0 \\
\hline Other & 0.3 & 0.2 & 0.5 & 1.5 & 0.4 & \\
\hline MTBE & 5.8 & 8.9 & 11.0 & 10.3 & 10.7 & 25.9 \\
\hline TAME & 6.6 & 6.9 & 4.5 & 5.2 & 4.7 & 7.7 \\
\hline THME & 0.1 & & & & & 0.5 \\
\hline
\end{tabular}




\begin{tabular}{|c|c|}
\hline \multicolumn{2}{|c|}{$\begin{array}{l}\text { Table B-9 (continued). } \\
\text { RFG blendstocks in PADD III for the year } 2010 \text { summer: } \\
\text { Methyl ether oxygenates } \\
\text { RFG minimum emissions reduction \%: VOC } 30 \text {; summer TAP } \\
26.5 ; \text { NOx } 7.8 \\
\text { RFG production share }=62 \%\end{array}$} \\
\hline 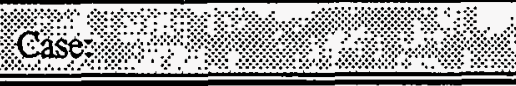 & $1.1 \% \mathrm{M}+$ \\
\hline RFG oxygen target, wt\% & 6.0 \\
\hline CG oxygen target, wt\% & 6.0 \\
\hline Crude reduction target, vol\% & 10 \\
\hline Oxygenate imports allowed, vol\% & 71 \\
\hline Forced hydrogenation? & No \\
\hline Blendstocks, $101 \% \%$ \% $/ 2 \%$ & 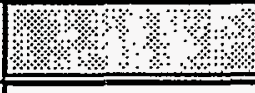 \\
\hline Butane & 1.5 \\
\hline Reformate. & 15.8 \\
\hline \multicolumn{2}{|l|}{ Straight nun naphtha } \\
\hline $\mathrm{C} 5+$ isomerate & 3.8 \\
\hline FCC naphtha & 3.5 \\
\hline \multicolumn{2}{|l|}{ Coker naphtha } \\
\hline \multicolumn{2}{|l|}{ Hydrocrackate } \\
\hline Alkylate & 1.2 \\
\hline Polymer gasolines & 21.3 \\
\hline \multicolumn{2}{|l|}{ Dimate } \\
\hline Toluene/xylene & 1.7 \\
\hline \multicolumn{2}{|l|}{ Natural gasoline } \\
\hline \multicolumn{2}{|l|}{ Pyrolysis gasoline } \\
\hline Raffinates & 16.7 \\
\hline \multicolumn{2}{|l|}{ Other } \\
\hline MTBE & 24.2 \\
\hline TAME & 8.6 \\
\hline THME & 1.8 \\
\hline
\end{tabular}




\begin{tabular}{|c|c|c|c|c|c|c|}
\hline \multicolumn{7}{|c|}{$\begin{array}{l}\text { Table B-10. } \\
\text { CG blendstocks in PADD III for the year } 2010 \text { summer: } \\
\text { Methyl ether oxygenates }\end{array}$} \\
\hline Case & $1 M$ & $2 \mathrm{MI}$ & $3 \mathrm{M}$ & $4 \mathrm{M}$ & $5 \mathrm{Nat}$ & $6 \mathrm{M}$ \\
\hline RFG oxygen target, wt\% & 2.1 & 2.7 & 2.7 & 2.7 & 2.7 & 6.0 \\
\hline CG oxygen target, wt\% & & 3.5 & 3.5 & 3.5 & 3.5 & 6.0 \\
\hline Crude reduction target, vol\% & & 10 & 10 & 15 & 10 & 10 \\
\hline $\begin{array}{l}\text { Oxygenate imports allowed, } \\
\text { vol\% }\end{array}$ & 43 & 43 & 0 & 43 & 43 & 43 \\
\hline Forced hydrogenation? & No & No & No & No & Yes & No \\
\hline \multicolumn{7}{|l|}{ Blendstocks; vol\% } \\
\hline Butane & 1.5 & 2.5 & 1.5 & 2.5 & 2.9 & 1.5 \\
\hline Reformate & 31.9 & 24.0 & 25.0 & 40.8 & 41.4 & 0.2 \\
\hline Straight run naphtha & 3.3 & 5.2 & 4.8 & 2.0 & 4.0 & \\
\hline $\mathrm{C} 5+$ isomerate & 1.7 & & & & & \\
\hline FCC naphtha & 36.0 & 34.5 & 26.8 & 19.3 & 17.4 & 38.7 \\
\hline Coker naphtha & 3.1 & 2.0 & 2.3 & 2.0 & 2.2 & \\
\hline Hydrocrackate & 4.7 & 0.4 & 11.6 & 9.6 & 9.7 & \\
\hline Alkylate & 17.7 & 11.1 & 3.9 & 0.6 & 2.4 & 13.7 \\
\hline Polymer gasolines & & & 4.1 & & & 12.4 \\
\hline \multicolumn{7}{|l|}{ Dimate } \\
\hline \multicolumn{7}{|l|}{ Toluene/xylene } \\
\hline Natural gasoline & & 0.9 & & 3.3 & & \\
\hline \multicolumn{7}{|l|}{ Pyrolysis gasoline } \\
\hline \multicolumn{7}{|l|}{ Raffinates } \\
\hline \multicolumn{7}{|l|}{ Other } \\
\hline MTBE & & 19.1 & 15.2 & 16.6 & 15.1 & 31.3 \\
\hline TAME & & 0.2 & 4.4 & 2.0 & 4.6 & 2.2 \\
\hline THME & & & 0.3 & 1.3 & 0.2 & \\
\hline
\end{tabular}




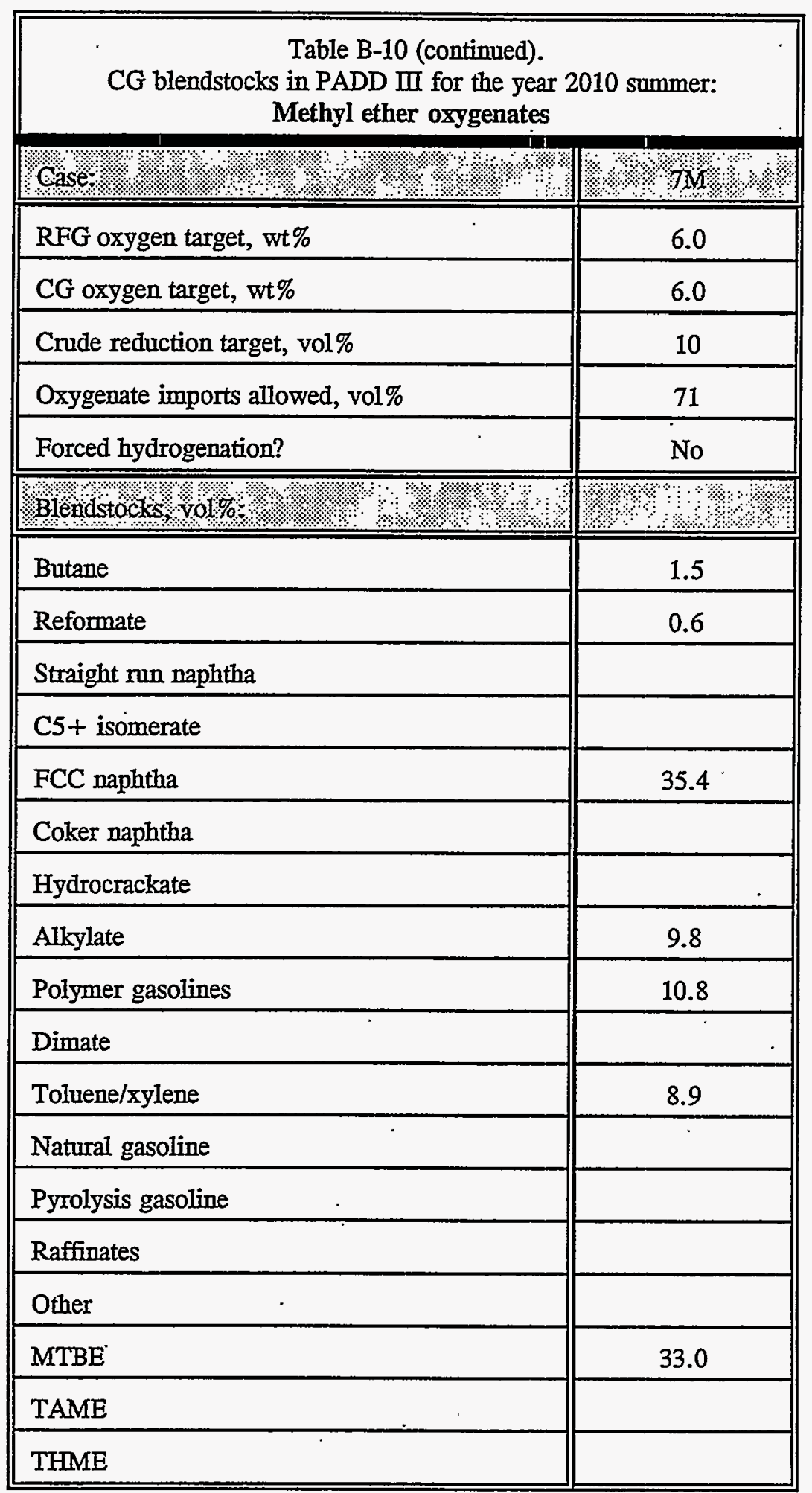




\begin{tabular}{|c|c|c|c|c|c|c|}
\hline $\begin{array}{r}\text { PADD III R } \\
\text { RFG minimum emissions }\end{array}$ & $\begin{array}{l}\text { Tak } \\
\text { G properti } \\
\text { Methyl et } \\
\text { eduction \% } \\
\text { G product }\end{array}$ & $\begin{array}{l}\text { le B-11. } \\
\text { s for the } \\
\text { ler oxyge } \\
\text { : VOC } \\
\text { on share }\end{array}$ & $\begin{array}{l}\text { ear } 2010 \\
\text { lates } \\
=62 \%\end{array}$ & $\begin{array}{l}\text { ummer: } \\
\text { TAP } 26 .\end{array}$ & NOx 7.8 & \\
\hline Case & $1 \mathrm{M}$ & $2 \mathrm{M}$ & $3 \mathrm{M}$ & $4 \mathrm{M}$ & $5 \mathrm{MU}$ & $6 \mathrm{M}$ \\
\hline RFG oxygen target, wt\% & 2.1 & 2.7 & 2.7 & 2.7 & 2.7 & 6.0 \\
\hline CG oxygen target, wt\% & & 3.5 & 3.5 & 3.5 & 3.5 & 6.0 \\
\hline Crude reduction target, vol\% & & 10 & 10 & 15 & 10 & 10 \\
\hline $\begin{array}{l}\text { Oxygenate imports allowed, } \\
\text { vol\% }\end{array}$ & 43 & 43 & 0 & 43 & 43 & 43 \\
\hline Forced hydrogenation? & No & No & No & No & Yes & No \\
\hline Properties $\mathrm{s}$ & अ. & ४ै। & धथ & :? & अ? & ২ \\
\hline Octane, $(\mathrm{R}+\mathrm{M}) / 2$ & 88.7 & 88.6 & 88.6 & 89.2 & 89.3 & 91.7 \\
\hline RVP, psi & 6.6 & 6.8 & 6.9 & 6.8 & 6.7 & 7.1 \\
\hline Aromatics, vol\% & 23.8 & 21.0 & 21.2 & 20.1 & 20.4 & 16.8 \\
\hline Benzene, vol\% & 0.90 & 0.90 & 0.90 & 0.90 & 0.90 & 0.57 \\
\hline Olefins, vol\% & 10.4 & 14.3 & 15.3 & 13.1 & 8.5 & 19.6 \\
\hline Sulfur, ppm & 139 & 104 & 87 & 115 & 103 & 48 \\
\hline $\mathrm{E} 200, \%$ & 49.9 & 48.9 & 48.9 & 49.4 & 49.4 & 49.4 \\
\hline E300, \% & 85.1 & 86.4 & 87.3 & 87.7 & 87.1 & 88.6 \\
\hline Oxygen, wt\% & 2.14 & 2.74 & 2.72 & 2.74 & 2.74 & 5.94 \\
\hline Specific gravity & .7426 & .7395 & .7413 & .7386 & .7378 & .7535 \\
\hline Summer TAP, mg/mi & 54.0 & 51.7 & 51.8 & 51.3 & 50.9 & 43.4 \\
\hline NOx, mg/mi & $1236^{\mathrm{a}}$ & $\underline{1234}$ & $\underline{1235}$ & 1225 & 1191 & $\underline{1239}$ \\
\hline $\mathrm{VOC}, \mathrm{mg}, \mathrm{mi}$ & $\underline{1008}$ & $\underline{1005}$ & 1008 & $\underline{1006}$ & $\underline{1004}$ & $\underline{1009}$ \\
\hline $\begin{array}{l}\mathrm{GHG}, \mathrm{CO}_{2} \text { equivalent gm/gal } \\
\text { (energy equivalent to base case } \\
\text { gasoline) }\end{array}$ & 12085 & 12070 & 12073 & 12064 & 12062 & 11995 \\
\hline
\end{tabular}




\begin{tabular}{|c|c|}
\hline \multicolumn{2}{|c|}{$\begin{array}{l}\text { Table B-11 (contimued). } \\
\text { PADD II RFG properties for the year } 2010 \text { summer: } \\
\text { Methyl ether oxygenates } \\
\text { RFG minimum emissions reduction \%: VOC } 30 \text {; summer TAP } \\
26.5 ; \text { NOx } 7.8 \\
\text { RFG production share }=62 \%\end{array}$} \\
\hline 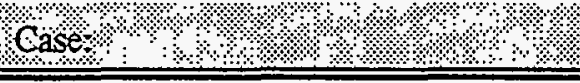 & १:. $2 \mathrm{M}$ \\
\hline RFG oxygen target, wt $\%$ & 6.0 \\
\hline CG oxygen target, wt\% & 6.0 \\
\hline Crude reduction target, vol\% & 10 \\
\hline Oxygenate imports allowed, vol\% & 71 \\
\hline Forced hydrogenation? & No \\
\hline Poperties $\%$ \% $\%$, $\%$ \% & \%.: \\
\hline Octane, $(\mathrm{R}+\mathrm{M}) / 2$ & 90.7 \\
\hline RVP, psi & 7.3 \\
\hline Aromatics, vol\% & 11.2 \\
\hline Benzene, vol\% & 0.61 \\
\hline Olefins, vol\% & 21.5 \\
\hline Sulfur, ppm & 49 \\
\hline $\mathrm{E} 200, \%$ & 48.9 \\
\hline $\mathrm{E} 300, \%$ & 89.5 \\
\hline Oxygen, wt $\%$ & 6.02 \\
\hline Specific gravity & .7448 \\
\hline Summer TAP, $\mathrm{mg} / \mathrm{mi}$ & 42.3 \\
\hline NOx, mg/mi & ${\underline{1235^{\mathrm{a}}}}^{2}$ \\
\hline VOC, mg,mi & $\underline{1008}$ \\
\hline $\begin{array}{l}\mathrm{GHG}, \mathrm{CO}_{2} \text { equivalent gm/gal (energy } \\
\text { equivalent to base case gasoline) }\end{array}$ & 11989 \\
\hline 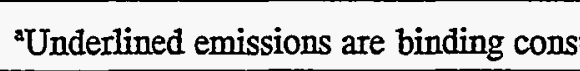 & \\
\hline
\end{tabular}




\begin{tabular}{|c|c|c|c|c|c|c|}
\hline \multicolumn{7}{|c|}{$\begin{array}{l}\text { Table B-12. } \\
\text { PADD III CG properties for the year } 2010 \text { summer: } \\
\text { Methyl ether oxygenates }\end{array}$} \\
\hline Case & $I M$ & $2 \mathrm{M}$ & $3 \mathrm{M}$ & $4 \mathrm{M}$ & $5 \mathrm{M}$ & $6 \mathrm{M}$ \\
\hline RFG oxygen target, wt\% & 2.1 & 2.7 & 2.7 & 2.7 & 2.7 & 6.0 \\
\hline CG oxygen target, wt\% & & 3.5 & 3.5 & 3.5 & 3.5 & 6.0 \\
\hline Crude reduction target, vol\% & & 10 & 10 & 15 & 10 & 10 \\
\hline $\begin{array}{l}\text { Oxygenate imports allowed, } \\
\text { vol\% }\end{array}$ & 43 & 43 & 0 & 43 & 43 & 43 \\
\hline Forced hydrogenation? & No & No & No & No & Yes & No \\
\hline Propertiest & ৷৷ & ४৷ & : & $\because$ & 3 & $\because \because$ \\
\hline Octane, $(\mathrm{R}+\mathrm{M}) / 2$ & 88.6 & 88.6 & 88.6 & 88.6 & 88.6 & 94.9 \\
\hline RVP, psi & 7.9 & 7.9 & 7.7 & 7.9 & 7.9 & 7.8 \\
\hline Aromatics, vol\% & 31.6 & 25.2 & 24.2 & 30.0 & 27.6 & 21.7 \\
\hline Benzene, vol\% & 1.66 & 1.11 & 1.34 & 1.63 & 1.57 & 0.56 \\
\hline Olefins, vol\% & 8.6 & 7.6 & 9.9 & 3.9 & 4.4 & 16.9 \\
\hline Sulfur, ppm & 351 & 419 & 385 & 244 & 290 & 247 \\
\hline E200, \% & 49.9 & 51.9 & 50.4 & 52.4 & 51.4 & 50.9 \\
\hline E300, \% & 82.2 & 84.4 & 84.9 & 84.4 & 84.9 & 61.5 \\
\hline Oxygen, wt\% & 0.00 & 3.47 & 3.49 & 3.43 & 3.45 & 5.97 \\
\hline Specific gravity & .7422 & .7473 & .7463 & .7587 & .7558 & .7452 \\
\hline Summer TAP, mg/mi & $\underline{78.5^{\mathrm{a}}}$ & 60.2 & 61.3 & 65.5 & 64.3 & 47.7 \\
\hline NOx, mg/mi & $\underline{1349}$ & $\underline{1343}$ & $\underline{1339}$ & 1291 & 1304 & $\underline{1343}$ \\
\hline $\mathrm{VOC}, \mathrm{mg} / \mathrm{mi}$ & 1256 & 1223 & 1172 & 1216 & 1216 & 1147 \\
\hline $\begin{array}{l}\mathrm{GHG}, \mathrm{CO}_{2} \text { equivalent gm/gal } \\
\text { (energy equivalent to base case } \\
\text { gasoline) }\end{array}$ & 12060 & 11991 & 11995 & 12000 & 11996 & 11944 \\
\hline
\end{tabular}




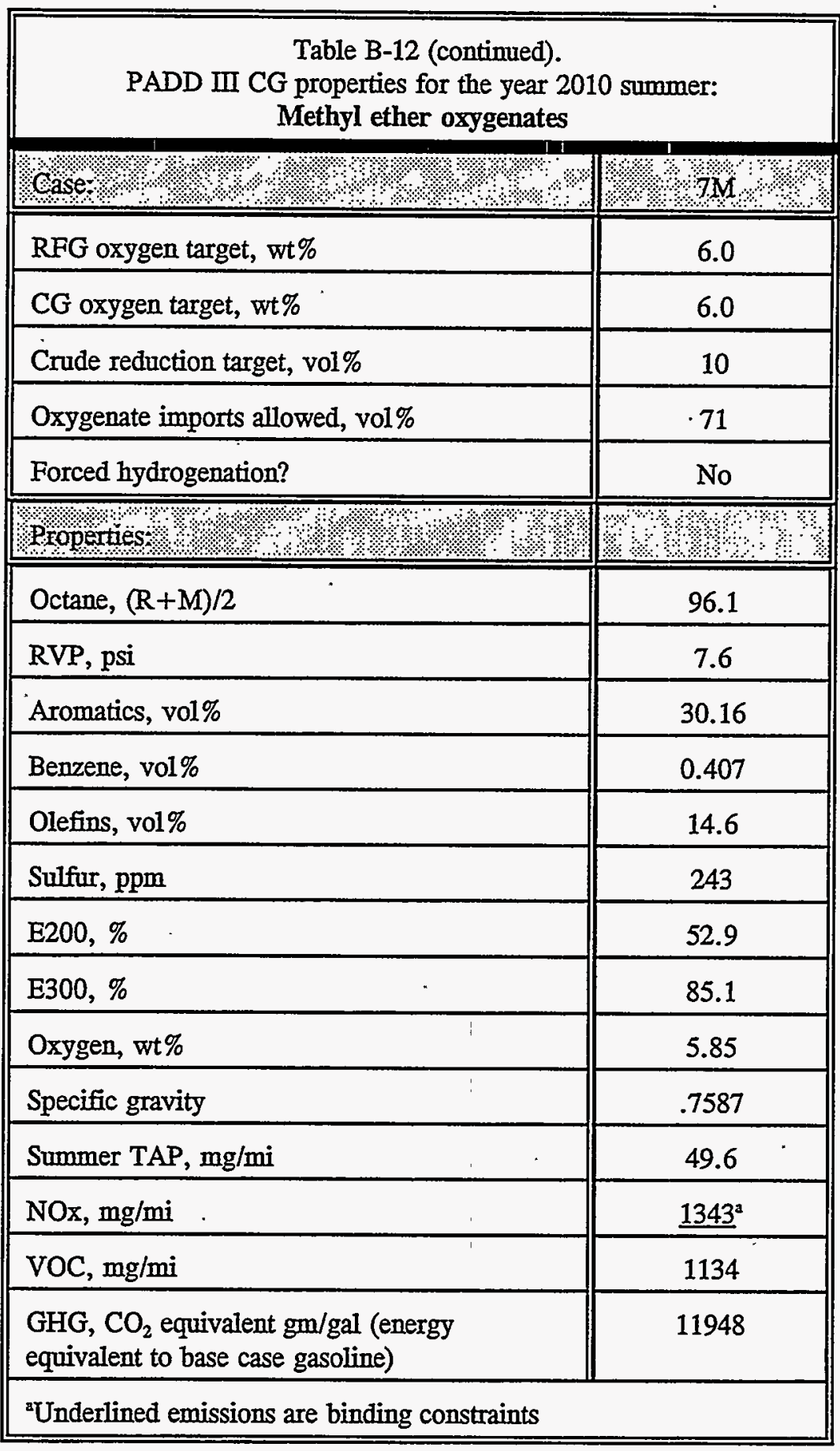


Table B-13. PADD III process capacity investments for the year 2010 summer: Methyl ether oxygenates

\begin{tabular}{|c|c|c|c|c|c|c|}
\hline Case & $1 \mathrm{M}$ & $2 \mathrm{M}$ & $\mathrm{SM}$ & 414 & $5 N+$ & $6 \mathrm{M}$ \\
\hline RFG oxygen target, wt\% & 2.1 & 2.7 & 2.7 & 2.7 & 2.7 & 6.0 \\
\hline CG oxygen target, wt\% & & 3.5 & 3.5 & 3.5 & 3.5 & 6.0 \\
\hline Crude reduction target, vo1\% & & 10 & 10 & 15 & 10 & 10 \\
\hline Oxygenate imports allowed, vol\% & 43 & 43 & 0 & 43 & 43 & 43 \\
\hline Forced hydrogenation? & No & No & No & No & Yes & No \\
\hline \multicolumn{7}{|c|}{ Process capacity investruents, $\mathrm{MBD}$} \\
\hline FCC feed hydrofiner & 322 & 231 & & & & 501 \\
\hline FCC gasoline fractionation & 82 & $\cdot 25$ & 112 & 497 & 86 & 1029 \\
\hline Polymerization & 20 & 122 & 237 & 168 & 37 & 576 \\
\hline Dimersol & 23 & & & & & \\
\hline Butane isomerization & 78 & 85 & 127 & 121 & & \\
\hline Butylene isomerization & 44 & & & & 8 & \\
\hline C5/C6 isomerization & 78 & 148 & 159 & 73 & 180 & \\
\hline Resid desulfurizer & & 77 & 214 & 27 & 217 & 432 \\
\hline Resid cracker & & 100 & 149 & 322 & 191 & \\
\hline Thermal cracker (gas feed) & & 59 & 77 & 86 & 122 & 431 \\
\hline Cryogenic fractionation & & 192 & 251 & 279 & 35 & 312 \\
\hline Dimerization (of ethylene) & & 101 & 256 & 198 & 15 & 309 \\
\hline Gas oil hydrocracker & & & 310 & 516 & 816 & 125 \\
\hline C2-C5 dehydrogenation & & & 244 & & & 332 \\
\hline Ether plant & & & 237 & & & 350 \\
\hline Hydrogen production (MMSCFD) & & & 496 & 1362 & 2721 & 1413 \\
\hline Naphtha cracker & & & & 2 & 129 & 735 \\
\hline Distillate deep hydrotreater & & & & 12 & 689 & 79 \\
\hline Sulfur plant, tons per day & & & 0.1 & 0.2 & 0.2 & 0.8 \\
\hline Coker (fluid) & & & & & & 260 \\
\hline Reformer & & & & & & 21 \\
\hline Reformate splitter & & & & & . & 11 \\
\hline Hydrogenation of $\mathrm{C} 5 / \mathrm{C} 6$ olefins & & & & & & 155 \\
\hline LPG aromatization & & & & & & 156 \\
\hline Investment cost (\$MM) & 3,016 & 9,829 & 32,054 & 25,811 & 24,435 & 54,038 \\
\hline
\end{tabular}




\begin{tabular}{|c|c|}
\hline \multicolumn{2}{|c|}{$\begin{array}{c}\text { Table B-13 (continued). PADD III process capacity investments for the year } 2010 \\
\text { summer: Methyl ether oxygenates) }\end{array}$} \\
\hline casel & $2,72 \%$ \\
\hline RFG oxygen target, wt\% & 6.0 \\
\hline CG oxygen target, wt\% & 6.0 \\
\hline Crude reduction target, vol\% & 10 \\
\hline Oygenate imports allowed, vol\% & 71 \\
\hline Forced hydrogenation? & No \\
\hline 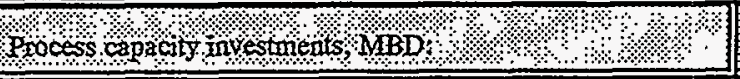 & 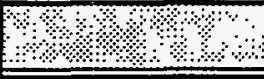 \\
\hline FCC feed hydrofiner & 513 \\
\hline FCC gasoline fractionation & 927 \\
\hline Polymerization & 585 \\
\hline \multicolumn{2}{|l|}{ Butane isomerization } \\
\hline Butylene isomerization & 15 \\
\hline $\mathrm{C} 5 / \mathrm{C} 6$ isomerization & 32 \\
\hline Resid desulfurizer & 432 \\
\hline Thermal cracker (gas feed) & 508 \\
\hline Cryogenic fractionation & 312 \\
\hline Dimerization (of ethylene) & 223 \\
\hline Gas oil hydrocracker & 105 \\
\hline C2-C5 dehydrogenation & 29 \\
\hline \multicolumn{2}{|l|}{ Ether plant } \\
\hline Hydrogen production (MMSCFD) & 1611 \\
\hline Naphtha cracker & 594 \\
\hline Distillate deep hydrotreater & 77 \\
\hline Sulfur plant, tons per day & 0.8 \\
\hline Coker (fluid) & 260 \\
\hline Reformer & 72 \\
\hline Reformate splitter & 13 \\
\hline Hydrogenation of $\mathrm{C} 5 / \mathrm{C} 6$ olefins & 156 \\
\hline LPG aromatization & 152 \\
\hline Aromatics recovery & 10 \\
\hline Investment cost (SMM) & 37,865 \\
\hline
\end{tabular}


Table B-14. PADD III low petroleum refinery fuel use for the year 2010 summer: Methyl ether oxygenates

\begin{tabular}{|c|c|c|c|c|c|c|c|}
\hline Case & Base: & $1 \mathrm{M}$ & $2 \mathrm{M}$ & $3 \mathrm{M}$ & $4 \mathrm{M}$ & $5 \mathrm{MN}$ & $6 \mathrm{M}$ \\
\hline RFG oxygen target, wt\% & & 2.1 & 2.7 & 2.7 & 2.7 & 2.7 & 6.0 \\
\hline CG oxygen target, wt\% & & & 3.5 & 3.5 & 3.5 & 3.5 & 6.0 \\
\hline $\begin{array}{l}\text { Crude reduction target, } \\
\text { vol\% }\end{array}$ & & & 10 & 10 & 15 & 10 & 10 \\
\hline $\begin{array}{l}\text { Oxygenate imports allowed, } \\
\text { vol\% }\end{array}$ & & 43 & 43 & 0 & 43 & 43 & 43 \\
\hline Forced hydrogenation? & & No & No & No & No & Yes & No \\
\hline $\begin{array}{l}\text { Refinery fuel use, energy } \\
\text { equivalent } \% \text { of inputs }\end{array}$ & 88 & & 90 & 97 & 113 & 107 & 15 \\
\hline
\end{tabular}

Table B-14 (contimed). PADD III low petroleum refinery fuel use for the year 2010 summer: Methyl ether oxygenates

\begin{tabular}{|c|c|}
\hline Case & $7 \mathrm{M}$ \\
\hline RFG oxygen target, wt\% & 6.0 \\
\hline CG oxygen target, wt\% & 6.0 \\
\hline Crude reduction target, vol\% & 10 \\
\hline Oygenate imports allowed, vol\% & 71 \\
\hline Forced hydrogenation? & No \\
\hline $\begin{array}{l}\text { Refriery ful ase energy equivalent } \% \text { of } \\
\text { inputs }\end{array}$ & का 11 \\
\hline
\end{tabular}




\begin{tabular}{|c|c|c|c|c|c|c|c|}
\hline \multicolumn{8}{|c|}{$\begin{array}{l}\text { Table B-15. } \\
\text { RFG blendstocks in PADD III for the year } 2010 \text { summer: } \\
\text { Ethyl ether oxygenates } \\
\text { RFG minimum emissions reduction \%: VOC 30; summer TAP 26.5; NOx } 7.8 \\
\text { RFG production share }=62 \%\end{array}$} \\
\hline $4 \mathrm{ase}$ & $1 \mathrm{E}$ & $2 E$ & $3 E$ & $4 \mathrm{~B}$ & SE: & $6 \mathrm{E}$ & 7Q: \\
\hline RFG oxygen target, wt\% & 2.1 & 2.7 & 2.7 & 2.7 & 6.0 & 6.0 & 6.0 \\
\hline CG oxygen target, wt\% & & 3.5 & 3.5 & 3.5 & 6.0 & 6.0 & 6.0 \\
\hline Crude reduction target, vol\% & & 10 & 15 & 10 & 10 & 10 & 17 \\
\hline Oxygenate imports allowed, vol\% & 43 & 43 & 43 & 43 & 43 & 43 & 43 \\
\hline Forced hydrogenation? & No & No & No & Yes & No & No & No \\
\hline Linear acetaldehyde emissions? & No & No & No & No & No & Yes & No \\
\hline Blendstock yol $\%$ \% & 3 & ४. & 3 & !n & 8 & . & ४। \\
\hline Butane & 1.5 & 1.5 & 1.5 & 1.5 & 3.2 & 2.2 & 2.7 \\
\hline Reformate & 25.6 & 19.7 & 12.2 & 19.7 & 14.2 & 21.0 & 13.5 \\
\hline Straight run naphtha & 4.4 & 9.4 & 5.0 & 1.8 & & & \\
\hline $\mathrm{C} 5+$ isomerate & 4.6 & 4.2 & 4.6 & 5.8 & 4.2 & 9.6 & 2.6 \\
\hline FCC naphtha & 22.1 & 25.6 & 21.6 & 20.1 & & 19.0 & \\
\hline Coker naphtha & 1.7 & & & & & & \\
\hline Hydrocrackate & 6.2 & 1.4 & 10.7 & 19.7 & 8.5 & & 8.5 \\
\hline Alkylate & 6.7 & 11.7 & 14.6 & 8.7 & 20.6 & & 24.1 \\
\hline Polymer gasolines & 1.5 & 2.8 & 7.9 & 1.5 & 3.5 & 5.0 & 3.7 \\
\hline Dimate & 3.5 & 2.0 & 0.2 & & & 0.2 & \\
\hline Toluene/xylene & 2.8 & 0.1 & & 0.1 & 0.1 & & \\
\hline Natural gasoline & & & & & & 1.2 & \\
\hline \multicolumn{8}{|l|}{ Pyrolysis gasoline } \\
\hline Raffinates & 4.7 & 3.0 & $3.3^{-}$ & 2.8 & 7.4 & 1.9 & 6.7 \\
\hline Other & 0.7 & 0.9 & 0.8 & 1.1 & & 0.8 & \\
\hline ETBE & 8.9 & 14.2 & 13.9 & 16.7 & 38.2 & 31.8 & 38.2 \\
\hline TAEE & 4.9 & 3.2 & 3.7 & 0.6 & & 7.0 & \\
\hline THEE & 0.1 & 0.2 & & & & 0.2 & \\
\hline
\end{tabular}




\begin{tabular}{|c|c|c|c|c|c|c|c|}
\hline \multicolumn{8}{|c|}{$\begin{array}{l}\text { Table B-16. } \\
\text { CG blendstocks in PADD III for the year } 2010 \text { summer: } \\
\text { Ethyl ether oxygenates }\end{array}$} \\
\hline 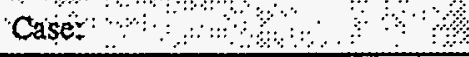 & $1 \mathrm{E}$ & $2 \mathrm{E}$ & $3 \mathrm{E}:$ & $4 \mathrm{E}$ & $5 E$ & $6 \mathrm{E}$ & IE \\
\hline RFG oxygen target, wt\% & 2.1 & 2.7 & 2.7 & 2.7 & 6.0 & 6.0 & 6.0 \\
\hline CG oxygen target, wt\% & & 3.5 & 3.5 & 3.5 & 6.0 & 6.0 & 6.0 \\
\hline Crude reduction target, vol\% & & 10 & 15 & 10 & 10 & 10 & 17 \\
\hline Oxygenate imports allowed, vol\% & 43 & 43 & 43 & 43 & 43 & 43 & 43 \\
\hline Forced hydrogenation? & No & No & No & Yes & No & No & No \\
\hline Linear acetaldehyde emissions? & No & No & No & No & No & Yes & No \\
\hline \multicolumn{8}{|l|}{ Blendstocks, vol $\%$, } \\
\hline Butane & 1.5 & 2.9 & 2.4 & 2.5 & 1.6 & 1.5 & 1.5 \\
\hline Reformate & 30.3 & 14.7 & 23.1 & 34.4 & & 0.5 & \\
\hline Straight run naphtha & & 4.5 & 5.1 & 5.5 & & 8.6 & \\
\hline $\mathrm{C5}+$ isomerate & & & & & 0.5 & & 3.3 \\
\hline FCC naphtha & 39.6 & 33.5 & 28.2 & 10.4 & 40.9 & 43.3 & 40.8 \\
\hline Coker naphtha & 0.5 & 4.8 & 4.0 & 4.8 & 4.6 & 4.6 & 3.2 \\
\hline Hydrocrackate & & 17.0 & 9.6 & 16.7 & 5.7 & 1.3 & 6.3 \\
\hline Alkylate & 16.0 & & & & & & \\
\hline Polymer gasolines & 9.8 & & & & & & \\
\hline \multicolumn{8}{|l|}{ Dimate } \\
\hline Toluene/xylene & 2.3 & & 0.2 & & & & \\
\hline Natural gasoline & & & 4.9 & 2.7 & & 0.7 & \\
\hline \multicolumn{8}{|l|}{ Pyrolysis gasoline } \\
\hline Raffinates & & & & & 2.8 & 0.6 & 1.8 \\
\hline Other & & & & & 3.8 & & 2.8 \\
\hline ETBE & & 20.0 & 20.2 & 17.5 & 25.6 & 33.6 & 24.0 \\
\hline TAEE & & 2.6 & 2.1 & 5.0 & 11.9 & 5.2 & 15.0 \\
\hline THEE & & & 0.3 & 0.5 & 2.6 & & 1.2 \\
\hline
\end{tabular}




\begin{tabular}{|c|c|c|c|c|c|c|c|}
\hline PADD II & $\begin{array}{l}\text { FG prope } \\
\text { Ethyl } \\
\text { reductior } \\
\text { RFG prod }\end{array}$ & $\begin{array}{l}\text { ble B-17 } \\
\text { ies for th } \\
\text { her oxyg } \\
\% \text { : VOC } \\
\text { ction shar }\end{array}$ & $\begin{array}{l}\text { year } 20 \\
\text { enates } \\
30 \text {; sum } \\
e=62 \%\end{array}$ & $\begin{array}{l}10 \text { summ } \\
\text { ner TAP }\end{array}$ & 26.5; NC & 7.8 & \\
\hline case +2 & 18. & $2 \mathrm{E}$ & 3E & $4 \mathrm{~B}$ & $\mathrm{SE}$ & $6 \mathrm{E}$ & \%E: \\
\hline RFG oxygen target, wt\% & 2.1 & 2.7 & 2.7 & 2.7 & 6.0 & 6.0 & 6.0 \\
\hline CG oxygen target, wt\% & & 3.5 & 3.5 & 3.5 & 6.0 & 6.0 & 6.0 \\
\hline Crude reduction target, vol\% & & 10 & 15 & 10 & 10 & 10 & 17 \\
\hline Oxygenate imports allowed, vol\% & 43 & 43 & 43 & 43 & 43 & 43 & 43 \\
\hline Forced hydrogenation? & No & No & No & Yes & No & No & No \\
\hline Linear acetaldehyde emissions? & No & No & No & No & No & Yes & No \\
\hline Properies, 4$) \%$ & 3.1 .9 & \%. & & $4 \%$ & २ै. & & 3 \\
\hline Octane, $(R+M) / 2$ & 89.0 & 88.8 & 89.3 & 89.4 & 96.7 & 93.3 & 97.1 \\
\hline RVP, psi & 6.6 & 6.7 & 6.9 & 6.7 & 6.5 & 6.5 & 6.5 \\
\hline Aromatics, vol\% & 24.6 & 20.8 & 13.7 & 16.7 & 10.0 & 15.2 & 10.0 \\
\hline Benzene, vol\% & 0.90 & 0.90 & 0.69 & 0.90 & 0.09 & 0.52 & 0.09 \\
\hline Olefins, vol\% & 1.1 & 12.6 & 14.2 & 7.6 & 3.9 & 9.8 & 4.1 \\
\hline Sulfur, ppm & 126 & 138 & 122 & 130 & 23 & 182 & 23 \\
\hline $\mathrm{E} 200, \%$ & 48.4 & 48.4 & 47.5 & 48.0 & 47.0 & 47.0 & 47.0 \\
\hline $\mathrm{E} 300, \%$ & 85.7 & 85.7 & 88.8 & 87.3 & 91.9 & 89.3 & 91.9 \\
\hline Oxygen, wt\% & 2.13 & 2.74 & 2.79 & 2.75 & 6.09 & 6.06 & 6.10 \\
\hline Specific gravity & .7441 & .7397 & .7263 & .7327 & .7335 & .7418 & .7316 \\
\hline Summer TAP, mg/mi & 57.9 & 57.2 & 52.8 & 55.1 & $\underline{58.1^{2}}$ & $\underline{58.2}$ & $\underline{58.2}$ \\
\hline NOx, mg/mi & $\underline{1234}$ & $\underline{1237}$ & 1205 & 1184 & 1078 & 1206 & 1078 \\
\hline VOC, $\mathrm{mg} / \mathrm{mi}$ & $\underline{1007}$ & $\underline{1005}$ & $\underline{1011}$ & $\underline{1008}$ & 964 & 984 & 964 \\
\hline $\mathrm{GHG}, \mathrm{CO}_{2}$ equivalent $\mathrm{gm} / \mathrm{gal}$ & $12173^{b}$ & 12198 & 12201 & 12193 & 12340 & 12350 & 12340 \\
\hline gasoline) & $11396^{c}$ & 11218 & 11218 & 11242 & 10133 & 10070 & 10133 \\
\hline $\begin{array}{l}{ }^{2} \text { Underlined emissions are binding } \\
\text { "Entry above dashed line is for et } \\
\text { "Entry below dashed line is for et }\end{array}$ & aints & n co & rive & anol & & & \\
\hline
\end{tabular}




\begin{tabular}{|c|c|c|c|c|c|c|c|}
\hline \multicolumn{8}{|c|}{$\begin{array}{l}\text { Table B-18. } \\
\text { PADD III CG properties for the year } 2010 \text { summer: } \\
\text { Ethyl ether oxygenates }\end{array}$} \\
\hline Case: & $1 \mathrm{E}$ & थख् & $3 \mathrm{E}$ & $4 \mathrm{E}$ & $5 \mathrm{E}$ & $6 \mathrm{E}$ & $\mathrm{ZE}$ \\
\hline RFG oxygen target, wt\% & 2.1 & 2.7 & 2.7 & 2.7 & 6.0 & 6.0 & 6.0 \\
\hline CG oxygen target, wt\% & & 3.5 & 3.5 & 3.5 & 6.0 & 6.0 & 6.0 \\
\hline Crude reduction target, vol\% & & 10 & 15 & 10 & 10 & 10 & 17 \\
\hline Oxygenate imports allowed, vol\% & 43 & 43 & 43 & 43 & 43 & 43 & 43 \\
\hline Forced hydrogenation? & No & No & No & Yes & No & No & No \\
\hline Linear acetaldehyde emissions? & No & No & No & No & No & Yes & No \\
\hline \multicolumn{8}{|l|}{ Propertes $\mathrm{s}$} \\
\hline Octane, $(\mathrm{R}+\mathrm{M}) / 2$ & 88.6 & 88.6 & 88.6 & 89.2 & 94.0 & 91.1 & 93.5 \\
\hline RVP, psi & 7.9 & 7.9 & 7.9 & 7.9 & 6.5 & 6.5 & 6.5 \\
\hline Aromatics, vol\% & 31.6 & 20.1 & 23.2 & 22.8 & 20.4 & 17.6 & 15.8 \\
\hline Benzene, vol\% & 1.59 & 1.15 & 1.36 & 1.71 & 0.92 & 0.72 & 0.76 \\
\hline Olefins, vol\% & 8.3 & 8.4 & 7.2 & 4.0 & 12.3 & 10.0 & 14.2 \\
\hline Sulfur, ppm & 379 & 542 & 451 & 297 & 500 & 550 & 461 \\
\hline $\mathrm{E} 200, \%$ & 42.6 & 48.0 & 48.4 & 48.0 & 42.1 & 46.5 & 42.1 \\
\hline $\mathrm{E} 300, \%$ & 82.2 & 85.3 & 84.9 & 87.3 & 84.9 & 87.9 & 85.3 \\
\hline Oxygen, wt\% & 0.00 & 3.55 & 3.52 & 3.53 & 6.04 & 6.05 & 6.08 \\
\hline Specific gravity & .7441 & .7372 & .7418 & .7436 & .7487 & .7414 & .7449 \\
\hline Summer TAP, mg/mi & 79.2 & 69.3 & 71.2 & 71.5 & 78.1 & 67.3 & 74.8 \\
\hline NOx, mg/mi & $\underline{1346^{2}}$ & $\underline{1343}$ & 1336 & 1285 & $\underline{1346}$ & 1327 & 1332 \\
\hline $\mathrm{VOC}, \mathrm{mg} / \mathrm{mi}$ & $\underline{1289}$ & 1237 & 1231 & 1210 & 1056 & 1046 & 1033 \\
\hline \multirow{2}{*}{$\begin{array}{l}\mathrm{GHG}, \mathrm{CO}_{2} \text { equivalent gm/gal } \\
\text { (energy equivalent to base case } \\
\text { gasoline) }\end{array}$} & \multirow[t]{2}{*}{12060} & $12220^{b}$ & 12219 & 12214 & 12342 & 12333 & 12342 \\
\hline & & $10951^{c}$ & 10949 & 10913 & 9976 & 10074 & 9969 \\
\hline
\end{tabular}




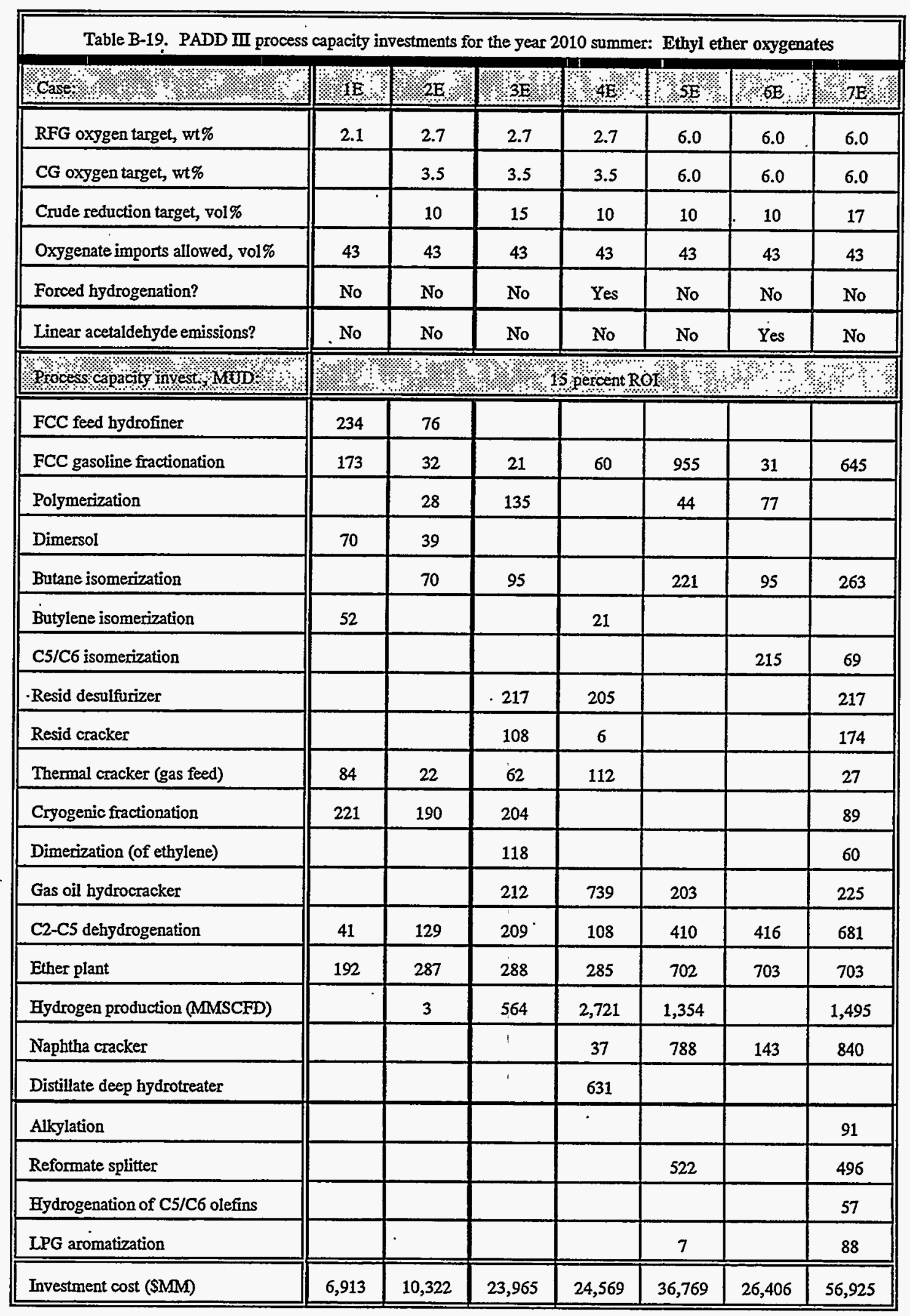


Table B-20. PADD III low petroleum refinery fuel use for the year 2010 summer: Ethyl ether oxygenates

\begin{tabular}{|c|c|c|c|c|c|c|c|c|}
\hline म & Base & $1 \mathrm{E}$ & $2 \mathrm{E}$ & $3 E$ & $4 \mathrm{E}$ & $\mathrm{SE}:$ & $6 \mathrm{E}$ & $7 \mathrm{E}$ \\
\hline $\begin{array}{l}\text { RFG oxygen target, } \\
\text { wt\% }\end{array}$ & & 2.1 & 2.7 & 2.7 & 2.7 & 6.0 & 6.0 & 6.0 \\
\hline $\begin{array}{l}\text { CG oxygen target, } \\
\text { wt\% }\end{array}$ & & & 3.5 & 3.5 & 3.5 & 6.0 & 6.0 & 6.0 \\
\hline $\begin{array}{l}\text { Crude reduction } \\
\text { target, vol\% }\end{array}$ & & & 10 & 15 & 10 & 10 & 10 & 17 \\
\hline $\begin{array}{l}\text { Oxygenate imports } \\
\text { allowed, vol\% }\end{array}$ & & 43 & 43 & 43 & 43 & 43 & 43 & 43 \\
\hline $\begin{array}{l}\text { Forced } \\
\text { hydrogenation? }\end{array}$ & & No & No & No & Yes & No & No & No \\
\hline $\begin{array}{l}\text { Linear acetaldehyde } \\
\text { emissions? }\end{array}$ & & No & No & No & No & No & Yes & No \\
\hline $\begin{array}{l}\text { Refinery fuel use } \\
\text { relative to Base }\end{array}$ & 88 & 101 & 92 & 99 & 10.4 & 10.5 & 82 & 10.6 \\
\hline
\end{tabular}




\begin{tabular}{|c|c|c|c|c|c|}
\hline \multicolumn{6}{|c|}{$\begin{array}{l}\text { Table B-21. RFG blendstocks in PADD III for the year } 2010 \text { summer: } \\
\text { Rapeseed oil feedstock } \\
\text { RFG minimum emissions reduction \%: VOC } 30 \text {; summer TAP 26.5; NOx } 7.8 \\
\text { RFG production share }=62 \%\end{array}$} \\
\hline $\mathrm{Case}$ & $2 \mathrm{M}$ & $1 \mathrm{R}$ & $1 \mathrm{R} \times$ & $5 \mathrm{E}$ & $2 \mathrm{RX}$ \\
\hline RFG oxygen target, wt\% & 2.7 & 2.7 & 2.7 & 6.0 & 6.0 \\
\hline CG oxygen target, wt\% & 3.5 & 3.5 & 3.5 & 6.0 & 6.0 \\
\hline $\begin{array}{l}\text { Ether type } \\
(M=\text { methyl; } E=\text { ethyl) }\end{array}$ & $\mathbf{M}$ & M & $\mathbf{M}$ & E & E \\
\hline Crude reduction target, vol\% & 10 & 10 & 10 & 10 & 10 \\
\hline Oxygenate imports allowed, vol\% & 43 & 43 & 43 & 43 & 43 \\
\hline Forced hydrogenation? & No & No & No & No & No \\
\hline Rapeseed oil feed? & No & Yes & Yes & No & Yes \\
\hline $\begin{array}{l}\text { FCC naphtha (rapeseed derived) } \\
\text { quality }\end{array}$ & NA & Low & High & NA & High \\
\hline \multicolumn{6}{|l|}{ Blendstocks rolo } \\
\hline Butane & 1.5 & 1.5 & 2.6 & 3.2 & 3.7 \\
\hline Reformate & 21.3 & 21.7 & 23.6 & 14.2 & 7.6 \\
\hline Straight run naphtha & 3.9 & 3.3 & 5.7 & & \\
\hline C5+ isomerate & 8.3 & 8.6 & 4.6 & 4.2 & \\
\hline FCC naphtha & 24.0 & 28.1 & 27.9 & & \\
\hline \multicolumn{6}{|l|}{ Coker naphtha } \\
\hline Hydrocrackate & 5.5 & 4.2 & 4.8 & 8.5 & 11.6 \\
\hline Alkylate & 8.7 & 9.2 & 7.5 & 20.6 & 20.6 \\
\hline Polymer gasolines & 7.3 & 3.7 & 5.2 & 3.5 & \\
\hline Toluene/xylene & 0.3 & 0.3 & 0.2 & 0.1 & 4.1 \\
\hline Raffinates & 3.2 & 3.6 & 3.2 & 7.4 & 14.2 \\
\hline Other & 0.2 & & & & \\
\hline MTBE & 8.9 & 8.8 & 14.8 & & \\
\hline TAME & 6.9 & 7.0 & & & \\
\hline ETBE & & & & 38.2 & 38.2 \\
\hline
\end{tabular}




\begin{tabular}{|c|c|c|c|c|c|}
\hline \multicolumn{6}{|c|}{$\begin{array}{l}\text { Table B-22. CG blendstocks in PADD III for the year } 2010 \text { summer: Rapeseed oil } \\
\text { feedstock }\end{array}$} \\
\hline Case, & $2 \mathrm{M}$ & $\mathrm{TR}$ & $1 \mathrm{Rx}$ & $5 \mathrm{E}$ & $2 \mathrm{RX}$ \\
\hline RFG oxygen target, wt\% & 2.7 & 2.7 & 2.7 & 6.0 & 6.0 \\
\hline CG oxygen target, wt\% & 3.5 & 3.5 & 3.5 & 6.0 & 6.0 \\
\hline $\begin{array}{l}\text { Ether type } \\
(M=\text { methyl; } E=\text { ethyl })\end{array}$ & $\mathbf{M}$ & M & M & E & $\mathrm{E}$ \\
\hline Crude reduction target, vol\% & 10 & 10 & 10 & 10 & 10 \\
\hline Oxygenate imports allowed, vol\% & 43 & 43 & 43 & 43 & 43 \\
\hline Forced hydrogenation? & No & No & No & No & No \\
\hline Rapeseed oil feed? & No & Yes & Yes & No & Yes \\
\hline $\begin{array}{l}\text { FCC naphtha (rapeseed derived) } \\
\text { quality. }\end{array}$ & NA & Low & High & NA & High \\
\hline Blendstocks, vol $\%$, & & ॥: & औ & +1: & $\because$ \\
\hline Butane & 2.5 & 2.1 & 2.7 & 1.6 & 1.8 \\
\hline Reformate & 24.0 & 18.2 & 15.2 & & \\
\hline Straight run naphtha & 5.2 & 5.1 & 3.0 & & \\
\hline C5 + isomerate & & & & 0.5 & \\
\hline FCC naphtha & 34.5 & 38.3 & 41.4 & 40.9 & 48.6 \\
\hline Coker naphtha & 2.0 & 2.3 & 2.3 & 4.6 & \\
\hline Hydrocrackate & 0.4 & & 0.3 & 5.7 & 9.4 \\
\hline Alkylate & $11 . i$ & 12.0 & 5.4 & & \\
\hline Polymer gasolines & & 2.4 & 1.4 & & \\
\hline Toluene/xylene & & & & & 0.3 \\
\hline Natural gasoline & 0.9 & & 8.2 & & \\
\hline Raffinates & & 0.3 & & 2.8 & \\
\hline Other & & & & 3.8 & 1.1 \\
\hline MTBE & 19.1 & 19.2 & 14.1 & & \\
\hline TAME & 0.2 & & 5.9 & & \\
\hline ETBE & & & & 25.6 & 35.8 \\
\hline TAEE & & & & 11.9 & 1.8 \\
\hline THEE & & & & 2.6 & 1.1 \\
\hline
\end{tabular}


Table B-23. PADD III RFG properties for the year 2010 summer: Rapeseed oil feedstock RFG minimum emissions reduction \%: VOC 30; summer TAP 26.5; NOx 7.8

RFG production share $=62 \%$

\begin{tabular}{|c|c|c|c|c|c|}
\hline Case & $22 \mathrm{MA}$ & HO & $1 \mathrm{RX}$ & $5 \mathrm{E}$ & $2 \mathrm{RX}$ \\
\hline RFG oxygen target, wt\% & 2.7 & 2.7 & 2.7 & 6.0 & 6.0 \\
\hline CG oxygen target, wt\% & 3.5 & 3.5 & 3.5 & 6.0 & 6.0 \\
\hline Ether type $(M=$ methyl; $E=$ ethyl) & $\mathbf{M}$ & $\mathrm{M}$ & $\mathbf{M}$ & $\mathrm{E}$ & $\mathrm{E}$ \\
\hline Crude reduction target, vol\% & 10 & 10 & 10 & 10 & 10 \\
\hline Oxygenate imports allowed, vol\% & 43 & 43 & 43 & 43 & 43 \\
\hline Forced hydrogenation? & No & No & No & No & No \\
\hline Rapeseed oil feed? & No & Yes & Yes & No & Yes \\
\hline FCC naphtha (rapeseed derived) quality & NA & Low & High & NA & High \\
\hline Propertes $\%$ \% & & & $\ldots$ & & \\
\hline Octane, $(R+M) / 2$ & 88.6 & 88.6 & 88.6 & 96.7 & 95.1 \\
\hline RVP, psi & 6.8 & 6.7 & 6.7 & 6.5 & 6.5 \\
\hline Aromatics, vol\% & 21.0 & 22.2 & 25.7 & 10.0 & 10.0 \\
\hline Benzene, vol\% & 0.90 & 0.9 & 0.90 & 0.09 & 0.07 \\
\hline Olefins, vol\% & 14.3 & 12.1 & 12.3 & 3.9 & 0.5 \\
\hline Sulfur, ppm & 104 & 109 & 104 & 23 & 22 \\
\hline $\mathrm{E} 200, \%$ & 48.9 & 49.4 & 49.4 & 47.0 & 46.5 \\
\hline $\mathrm{E} 300, \%$ & 86.4 & 85.5 & 86.6 & 91.9 & 91.2 \\
\hline Oxygen, wt\% & 2.74 & 2.73 & 2.67 & 6.09 & 6.06 \\
\hline Specific gravity & .7395 & .7422 & .7470 & .7335 & .7364 \\
\hline Summer TAP, mg/mi & 51.7 & 52.0 & 53.9 & $\underline{58.1^{2}}$ & $\underline{58.1}$ \\
\hline NOx, mg/mi & $\underline{1234}$ & 1224 & $\underline{1234}$ & 1078 & 1077 \\
\hline VOC, mg/mi & 1005 & 1008 & 1008 & 964 & 972 \\
\hline \multirow{2}{*}{$\begin{array}{l}\mathrm{GHG}, \mathrm{CO}_{2} \text { equivalent gm/gal (energy } \\
\text { equivalent to base case gasoline). }\end{array}$} & \multirow[t]{2}{*}{12070} & \multirow[t]{2}{*}{12067} & \multirow[t]{2}{*}{12074} & $12340^{b}$ & 12342 \\
\hline & & & & $10133^{c}$ & 10135 \\
\hline $\begin{array}{l}\text { aUnderlined emissions are binding constraints } \\
{ }^{b} \text { Entry above dashed line is for ethers produced } \\
\text { 'Entry below dashed line is for ethers produced }\end{array}$ & rom cos & A $\cdot$ & lanol & & \\
\hline
\end{tabular}




\begin{tabular}{|c|c|c|c|c|c|}
\hline Casen $)$ औ & $2 \mathrm{M}$ & 18 & $\mathrm{tRX}$ & 蓜 & $2 R X$ \\
\hline RFG oxygen target, wt\% & 2.7 & 2.7 & 2.7 & 6.0 & 6.0 \\
\hline CG oxygen target, wt\% & 3.5 & 3.5 & 3.5 & 6.0 & 6.0 \\
\hline $\begin{array}{l}\text { Ether type } \\
(M=\text { methyl; } E=\text { ethyl })\end{array}$ & M & $\mathbf{M}$ & $\mathbf{M}$ & E & $\mathrm{E}$ \\
\hline Crude reduction target, vol\% & 10 & 10 & 10 & 10 & 10 \\
\hline Oxygenate imports allowed, vol\% & 43 & 43 & 43 & 43 & 43 \\
\hline Forced hydrogenation? & No & No & No & No & No \\
\hline Rapeseed oil feed? & No & Yes & Yes & No & Yes \\
\hline FCC naphtha (rapeseed derived) quality & NA & Low & High & NA & High \\
\hline Properties & $\therefore$ & 4 & : & 3 & $\vdots$ \\
\hline Octane, $(R+M) / 2$ & 88.6 & 88.7 & 89.1 & 94.0 & 95.9 \\
\hline RVP, psi & 7.9 & 7.9 & 7.9 & 6.5 & 6.5 \\
\hline Aromatics, vol\% & 25.2 & 22.0 & 24.1 & 20.4 & 20.6 \\
\hline Benzene, vol\% & 1.11 & 1.01 & 0.98 & 0.92 & 0.81 \\
\hline Olefins, vol\% & 7.6 & 12.8 & 11.7 & 12.3 & 11.5 \\
\hline Sulfur, ppm & 419 & 353 & 369 & 500 & 473 \\
\hline E200, \% & 51.9 & 51.9 & 49.9 & 42.1 & 47.5 \\
\hline $\mathrm{E} 300, \%$ & 84.4 & 84.6 & 85.1 & 84.9 & 85.3 \\
\hline Oxygen, wt\% & 3.47 & 3.48 & 3.51 & 6.04 & 6.02 \\
\hline Specific gravity & .7473 & .7433 & .7445 & .7487 & .7443 \\
\hline Summer TAP, mg/mi & 60.2 & 56.5 & 57.4 & 78.1 & 75.6 \\
\hline NOx, mg/mi & $1343^{a}$ & $\underline{1346}$ & 1347 & 1346 & 1342 \\
\hline VOC, $\mathrm{mg} / \mathrm{mi}$ & 1223 & 1190 & 1205 & 1056 & 1035 \\
\hline \multirow{2}{*}{$\begin{array}{l}\mathrm{GHG}, \mathrm{CO}_{2} \text { equivalent gm/gal (energy } \\
\text { equivalent to base case gasoline) }\end{array}$} & \multirow[t]{2}{*}{11911} & \multirow[t]{2}{*}{11996} & \multirow[t]{2}{*}{11993} & $12340^{\mathrm{b}}$ & 12329 \\
\hline & & & & $9976^{c}$ & 10089 \\
\hline $\begin{array}{l}{ }^{2} \text { Underlined emissions are binding cons } \\
\text { 'Entry above dashed line is for ethers } \\
\text { 'Entry below dashed line is for ethers }\end{array}$ & 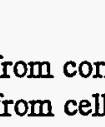 & ack & hanol & & \\
\hline
\end{tabular}




\begin{tabular}{|c|c|c|c|c|c|}
\hline \multicolumn{6}{|c|}{$\begin{array}{l}\text { Table B-25. PADD III process capacity investments for the year } 2010 \text { summer: Rapeseed oil } \\
\text { feedstock }\end{array}$} \\
\hline $\mathrm{case}, 4,4$ & $201 \%$ & 10 & $\mathrm{HX}$ & SE & $2 R \times$ \\
\hline RFG oxygen target, wt\% & 2.7 & 2.7 & 2.7 & 6.0 & 6.0 \\
\hline CG oxygen target, wt\% & 3.5 & 3.5 & 3.5 & 6.0 & 6.0 \\
\hline $\begin{array}{l}\text { Ether type } \\
(M=\text { methyl; }: E=\text { ethyl })\end{array}$ & $\mathbf{M}$ & $\mathbf{M}$ & M & $\mathbf{E}$ & $\mathrm{E}$ \\
\hline Crude reduction target, vol\% & 10 & 10 & 10 & 10 & 10 \\
\hline Oxygenate imports allowed, vol\% & 43 & 43 & 43 & 43 & 43 \\
\hline Forced hydrogenation? & No & No & No & No & No \\
\hline Rapeseed oil feed? & No & Yes & Yes & No & Yes \\
\hline FCC naphtha (repeseed derived) quality & $\mathrm{NA}$ & Low & High & NA & High \\
\hline 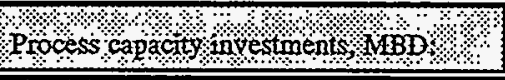 & $2 \%$ & 3 & ४ & perentige & $\mathrm{P}$ \\
\hline FCC feed hydrofiner & 231 & 620 & 610 & & \\
\hline FCC gasoline fractionation & 25 & & & 955 & 385 \\
\hline Polymerization & 122 & 78 & 97 & 44 & \\
\hline Butane isomerization & 85 & 92 & 56 & 221 & 271 \\
\hline Butylene isomerization & & 20 & & & 46 \\
\hline C5/C6 isomerization & 148 & 160 & & & \\
\hline Resid desulfurizer & 77 & 21 & 125 & & \\
\hline Resid cracker & 100 & 150 & 162 & & \\
\hline Thermal cracker (gas feed) & 59 & 57 & & & \\
\hline Cryogenic fractionation & 192 & 186 & 177 & & \\
\hline Dimerization (of ethylene) & 101 & 98 & 23 & & \\
\hline Gas oil hydrocracker & & & & 203 & 447 \\
\hline C2-C5 dehydrogenation & & & & 410 & 489 \\
\hline Ether plant & & & & 702 & 685 \\
\hline Eydrogen production (MMSCFD) & & & & 1,354 & 2,106 \\
\hline Naphtha cracker & & & & 788 & 1,025 \\
\hline Distillate deep hydrotreater & & 18 & 13 & & \\
\hline Reformate splitter & & 50 & & 522 & 279 \\
\hline LPG aromatization & & & & 7 & 106 \\
\hline Investment cost (\$MM) & 9,829 & $\begin{array}{c}10,94 \\
1\end{array}$ & 8,013 & 36,769 & 44,596 \\
\hline
\end{tabular}


Table B-26. PADD III low petroleum refinery fuel use for the year 2010 summer: Rapeseed oil feedstock

\begin{tabular}{|c|c|c|c|c|c|c|}
\hline 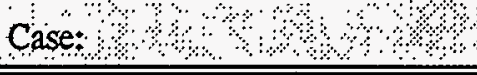 & Base & $2 \mathrm{M}$ & $1 \mathrm{R}$ & $\mathrm{RX}$ & SE & $2 \mathrm{RX}$ \\
\hline RFG oxygen target, wt\% & & 2.7 & 2.7 & 2.7 & 6.0 & 6.0 \\
\hline CG oxygen target, wt\% & & 3.5 & 3.5 & 3.5 & 6.0 & 6.0 \\
\hline $\begin{array}{l}\text { Ether type } \\
(\mathrm{M}=\text { methyl; } \mathrm{E}=\text { ethyl })\end{array}$ & & $\mathbf{M}$ & $\mathbf{M}$ & M & $\mathrm{E}$ & $\mathrm{E}$ \\
\hline Crude reduction target, vol\% & & 10 & 10 & 10 & 10 & 10 \\
\hline $\begin{array}{l}\text { Oxygenate imports allowed, } \\
\text { vol\% }\end{array}$ & & 43 & 43 & 43. & 43 & 43 \\
\hline Force hydrogenation? & & No & No & No & No & No \\
\hline Rapeseed oil feed? & & No & Yes & Yes & No & Yes \\
\hline $\begin{array}{l}\text { FCC naphtha (rapeseed } \\
\text { derived) quality }\end{array}$ & & NA & Low & High & NA & High \\
\hline $\begin{array}{l}\text { Refinery fuel use energy } \\
\text { equitivalent } \% \text { of inputs }\end{array}$ & ' & $9: 0$ & 8.8 & 8.9 & 0 & 110 \\
\hline
\end{tabular}


APPENDIX C

HYDROGEN REPLACEMENT FUEL CREDITS 
Hydrogen derived from non-petroleum sources is credited to low petroleum gasoline according to the following arbitrary procedure:

To determine the percentage of total hydrogen that enters refined product, deduct hydrogen used in desulfurization or in fuel gas:

Fraction of $\mathrm{H}_{2}$ used in desulfurization and fuel gas $=f$, where

$$
f=\left(\mathrm{H}_{2} \text { to } \mathrm{H}_{2} \mathrm{~S}+\mathrm{H}_{2} \text { to fuel gas }\right) /\left(\text { Total } \mathrm{H}_{2}\right)
$$

Percent $\mathrm{H}_{2}$ to product $=100 *(1-\mathrm{f})$

Of the $\mathrm{H}_{2}$ that enters product, assume that the percentage that enters low petroleum gasoline is proportional to the percentage of hydrocracked stocks that enter gasoline:

Percent $\mathrm{H}_{2}$ that enters low petroleum gasoline $=\mathrm{s}$, where

$\mathrm{s}=100 *(1-\mathrm{f}) *($ hydrocracked stocks that enter gasoline/total hydrocracked blend stocks)

Finally, assume that the percentage of hydrogen derived from non-petroleum sources, which can be credited to low petroleum gasoline, is:

$\mathrm{s} *\left(\right.$ Non-petroleum-derived $\mathrm{H}_{2}$ /Total purchased and generated $\mathrm{H}_{2}$ ). 


\section{APPENDIX D \\ BLENDSTOCKS, PROPERTIES, PROCESS INVESTMENTS, AND FUEL USE FOR WINTER GASOLINE PRODUCTION}




\begin{tabular}{|c|c|}
\hline \multicolumn{2}{|c|}{$\begin{array}{l}\text { Table D-1. } \\
\text { PADD III base case blendstocks for year } \\
2010 \text { winter }\end{array}$} \\
\hline Blendstock & Percent \\
\hline Butane & 8.8 \\
\hline Reformate & 27.1 \\
\hline Straight run naphtha & 1.4 \\
\hline $\mathrm{C} 5+$ isomerate & 6.1 \\
\hline FCC naphtha & 33.3 \\
\hline Coker naphtha & 1.4 \\
\hline Hydrocrackate & 3.8 \\
\hline Alkylate & 10.8 \\
\hline Polymer gasolines & 5.1 \\
\hline Dimate & 0.1 \\
\hline \multicolumn{2}{|l|}{ MTBE } \\
\hline Toluene/xylene & 0.2 \\
\hline Natural gasoline & 0.6 \\
\hline \multicolumn{2}{|l|}{ Pyrolysis gasoline } \\
\hline Raffinates & 1.4 \\
\hline Other & \\
\hline
\end{tabular}

D-1 


\begin{tabular}{||l||c||}
\hline \multicolumn{2}{||c||}{$\begin{array}{c}\text { Table D-2. PADD II base case gasoline } \\
\text { properties for the year } 2010 \text { winter }\end{array}$} \\
\hline Octane, $(\mathrm{R}+\mathrm{M}) / 2$ & 88.7 \\
\hline RVP, psi & 12.5 \\
\hline Aromatics, vol\% & 30.0 \\
\hline Benzene, vol\% & 2.04 \\
\hline Olefins, vol\% & 13.3 \\
\hline Sulfur, ppm & 361 \\
\hline E200, \% & 53.3 \\
\hline E300, \% & 82.9 \\
\hline Specific gravity & .7284 \\
\hline Winter TAP, mg/mi & 115.4 \\
\hline NOx, mg/mi & 1578 \\
\hline $\begin{array}{l}\text { GHG, CO } 2 \text { equivalent } \\
\text { gm/gal (energy equivalent } \\
\text { to base case gasoline) }\end{array}$ & 11613 \\
\hline
\end{tabular}

D-2 


\begin{tabular}{|c|c|c|c|}
\hline \multicolumn{4}{|c|}{$\begin{array}{l}\text { Table D-3. } \\
\text { RFG blendstocks in PADD III for the year } 2010 \\
\text { RFG minimum emissions reduction \%: winter TAP 16.8; NOx (no increase) } \\
\text { RFG production share }=62 \%\end{array}$} \\
\hline Case & EAW: & $M W$ & $\mathrm{EW}$ \\
\hline RFG oxygen target, wt\% & 6.0 & 6.0 & 6.0 \\
\hline CG oxygen target, wt\% & 6.0 & 6.0 & 6.0 \\
\hline Oxygenate type & Ethanol & Methyl ethers & Ethyl ethers \\
\hline Crude reduction target, vol\% & 10 & 10 & 10 \\
\hline $\begin{array}{l}\text { Oxygenate imports allowed, } \\
\text { vol\% }\end{array}$ & & 66 & 70 \\
\hline \multicolumn{4}{|l|}{ Blendstocks, yol $\%$, } \\
\hline Butane & 7.8 & 8.8 & 9.5 \\
\hline Reformate & 4.5 & 23.4 & \\
\hline Straight run naphtha & 9.8 & & \\
\hline $\mathrm{C} 5+$ isomerate & & & 4.0 \\
\hline FCC naphtha & 36.1 & 18.4 & 32.0 \\
\hline Coker naphtha & 0.3 & & 1.8 \\
\hline Hydrocrackate & & & 4.3 \\
\hline Alkylate & 14.4 & 2.6 & \\
\hline Polymer gasolines & 6.9 & 13.4 & 4.7 \\
\hline \multicolumn{4}{|l|}{ Dimate } \\
\hline Toluene/xylene & 0.4 & 0.4 & \\
\hline \multicolumn{4}{|l|}{ Natural gasoline } \\
\hline \multicolumn{4}{|l|}{ Pyrolysis gasoline } \\
\hline Raffinates & 2.3 & & 5.5 \\
\hline Other & 0.2 & & \\
\hline MTBE & & 32.5 & \\
\hline THME & & 0.6 & \\
\hline Ethanol & 17.3 & & \\
\hline ETBE & & & 38.2 \\
\hline
\end{tabular}

D-3 


\begin{tabular}{|c|c|c|c|}
\hline \multicolumn{4}{|c|}{$\begin{array}{l}\text { Table D-4. } \\
\text { CG blendstocks in PADD III for the year } 2010 \text { winter }\end{array}$} \\
\hline $\mathrm{Case} / 4,4$ ४ & अ. $\mathrm{AWW}$ & m.MW! & EWt: \\
\hline RFG oxygen target, wt\% & 6.0 & 6.0 & 6.0 \\
\hline CG oxygen target, wt\% & 6.0 & 6.0 & 6.0 \\
\hline Oxygenate type & Ethanol & Methyl ethers & Ethyl ethers \\
\hline Crude reduction target, vol\% & 10 & 10 & 10 \\
\hline $\begin{array}{l}\text { Oxygenate imports allowed, } \\
\text { vol\% }\end{array}$ & & 66 & 70 \\
\hline \multicolumn{4}{|l|}{ Blendstocks, vol $\%$} \\
\hline Butane & 9.4 & 9.2 & 10.2 \\
\hline Reformate & 43.4 & & 30.4 \\
\hline Straight run naphtha & 1.8 & & \\
\hline $\mathrm{C} 5+$ isomerate & 0.2 & 7.1 & 8.5 \\
\hline FCC naphtha & 8.9 & 20.6 & 4.7 \\
\hline Coker naphtha & 2.0 & & \\
\hline \multicolumn{4}{|l|}{ Hydrocrackate } \\
\hline Alkylate & 5.5 & 6.8 & \\
\hline Polymer gasolines & 2.9 & 15.1 & \\
\hline \multicolumn{4}{|l|}{ Dimate } \\
\hline Toluene/xylene & & & 5.0 \\
\hline Natural gasoline & 8.7 & & \\
\hline \multicolumn{4}{|l|}{ Pyrolysis gasoline } \\
\hline Raffinates & & 3.6 & 3.1 \\
\hline Other & & 3.0 & \\
\hline MTBE & & 24.0 & \\
\hline TAME & & 8.9 & \\
\hline THME & & 1.8 & \\
\hline Ethanol & 17.3 & & \\
\hline ETBE & & & 38.2 \\
\hline
\end{tabular}

D-4 


\begin{tabular}{|c|c|c|c|}
\hline \multicolumn{4}{|c|}{$\begin{array}{l}\text { Table D-5. } \\
\text { PADD III RFG properties for the year } 2010 \text { winter } \\
\text { RFG minimum emissions reduction \%: winter TAP 16.8; NOx (no increase) } \\
\text { RFG production share }=62 \%\end{array}$} \\
\hline Case & ZAW & MW & $\mathrm{EW}$ \\
\hline RFG oxygen target, wt\% & 6.0 & 6.0 & 6.0 \\
\hline CG oxygen target, wt\% & 6.0 & 6.0 & 6.0 \\
\hline Oxygenate typ & Ethanol & Methyl ethers & Ethyl ethers \\
\hline Crude reduction target, vol\% & 10 & 10 & 10 \\
\hline $\begin{array}{l}\text { Oxygenate imports allowed, } \\
\text { vol\% }\end{array}$ & & 66 & 70 \\
\hline \multicolumn{4}{|l|}{ Propertiess ${ }^{\prime}$ : } \\
\hline Octane, $(\mathrm{R}+\mathrm{M}) / 2$ & 89.6 & 94.6 & 94.1 \\
\hline RVP, psi & 14.0 & 11.6 & 11.6 \\
\hline Aromatics, vol\% & 14.3 & 20.2 & 10.1 \\
\hline Benzene, vol\% & 0.59 & 0.90 & 0.57 \\
\hline Olefins, vol\% & 16.9 & 16.4 & 15.2 \\
\hline Sulfur, ppm & 295 & 260 & 261 \\
\hline $\mathrm{E} 200, \%$ & 60.2 & 56.3 & 55.8 \\
\hline $\mathrm{E} 300, \%$ & 91.45 & 88.6 & 89.7 \\
\hline Oxygen, wt\% & 6.32 & 5.97 & 6.18 \\
\hline Specific gravity & .7268 & .7437 & .7221 \\
\hline Winter TAP, mg/mi & 76.0 & 67.7 & 82.9 \\
\hline $\mathrm{NOx}, \mathrm{mg} / \mathrm{mi}$. & 1519 & $1528^{\mathrm{a}}$ & 1448 \\
\hline \multirow{2}{*}{$\begin{array}{l}\mathrm{GHG}, \mathrm{CO}_{2} \text { equivalent } \mathrm{gm} / \mathrm{gal} \\
\text { (energy equivalent to base case } \\
\text { gasoline) }\end{array}$} & $11969^{b}$ & \multirow[t]{2}{*}{11523} & 11938 \\
\hline & $10109^{c}$ & & 9827 \\
\hline \multicolumn{4}{|c|}{$\begin{array}{l}\text { 'Underlined emissions are binding constraints } \\
\text { 'Entry above dashed line is for corn-derived ethanol or for ethers produced from } \\
\text { corn-derived ethanol } \\
\text { 'Entry below dashed line is for cellulosic ethanol or for ethers produced from } \\
\text { cellulosic ethanol }\end{array}$} \\
\hline
\end{tabular}




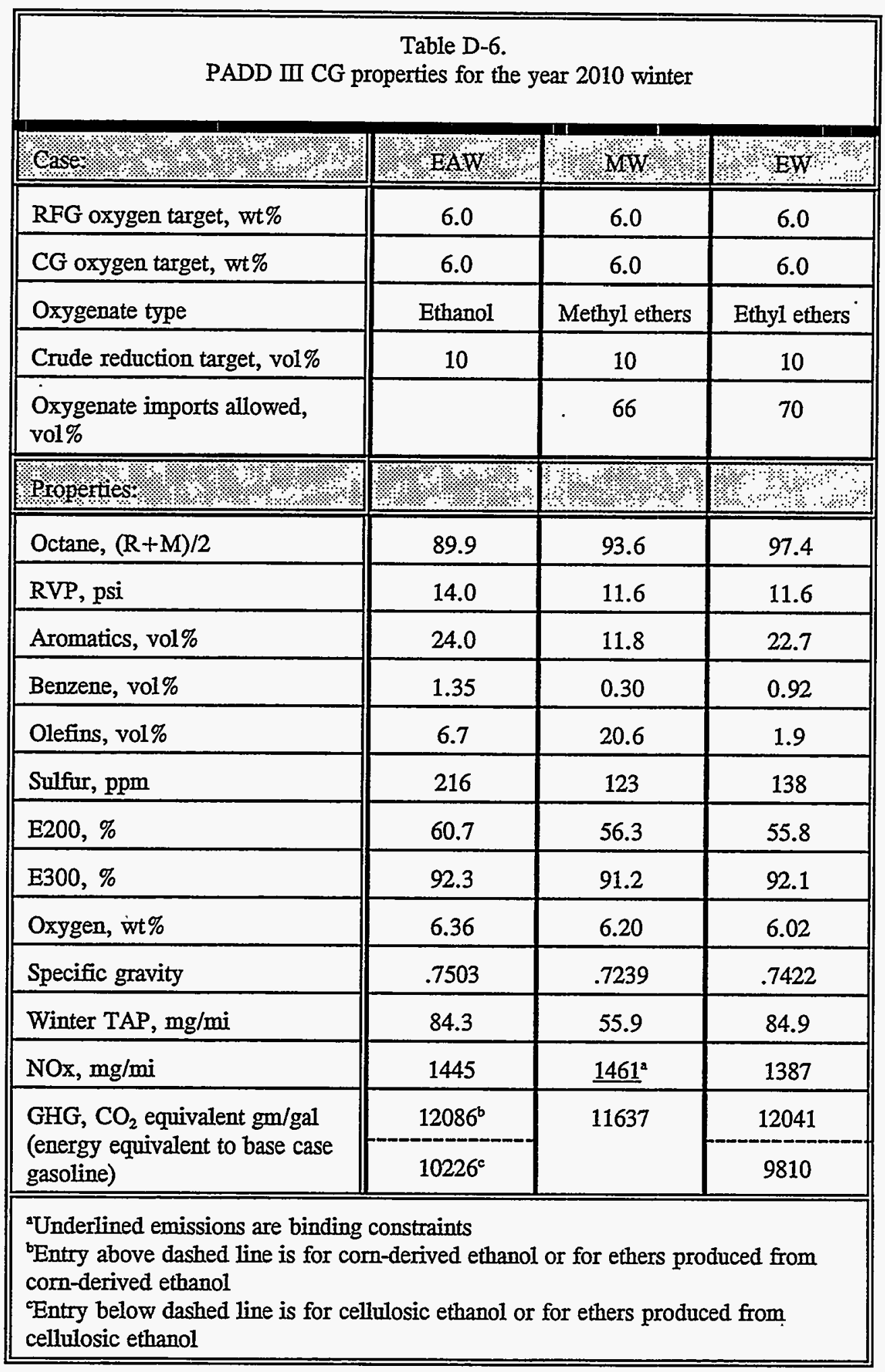


Table D-7. PADD III process capacity investments for the year 2010 winter

\begin{tabular}{|c|c|c|c|}
\hline Case & WEWW & MW & EW : \\
\hline RFG oxygen target, wt\% & 6.0 & 6.0 & 6.0 \\
\hline CG oxygen target, wt\% & 6.0 & 6.0 & 6.0 \\
\hline Oxygenate type & Ethanol & Methyl ethers & Ethyl ethers \\
\hline Crude reduction target, vol\% & 10 & 10 & 10 \\
\hline $\begin{array}{l}\text { Oxygenate imports allowed, } \\
\text { vol\% }\end{array}$ & & 66 & 70 \\
\hline Process capacity investments, & ?: & 15 percent Ror & \\
\hline FCC feed hydrofiner & & 272 & \\
\hline FCC gasoline fractionation & & 969 & 71 \\
\hline Polymerization & 18 & 289 & \\
\hline Resid desulfurizer & 104 & 85 & \\
\hline Resid cracker & & 4 & \\
\hline Thermal cracker (gas feed) & & 71 & \\
\hline Cryogenic fractionation & 206 & 234 & \\
\hline Dimerization (of ethylene) & 157 & 193 & \\
\hline C2-C5 dehydrogenation & & 78 & \\
\hline $\begin{array}{l}\text { Hydrogen production } \\
\text { (MMSCFD) }\end{array}$ & 135 & & 248 \\
\hline Naphtha cracker & 175 & 318 & 358 \\
\hline Hydrogenation of C5/C6 olefins & & 22 & \\
\hline LPG aromatization & & & 105 \\
\hline Investment cost (\$MM) & 7,224 & 16,181 & 4,219 \\
\hline
\end{tabular}




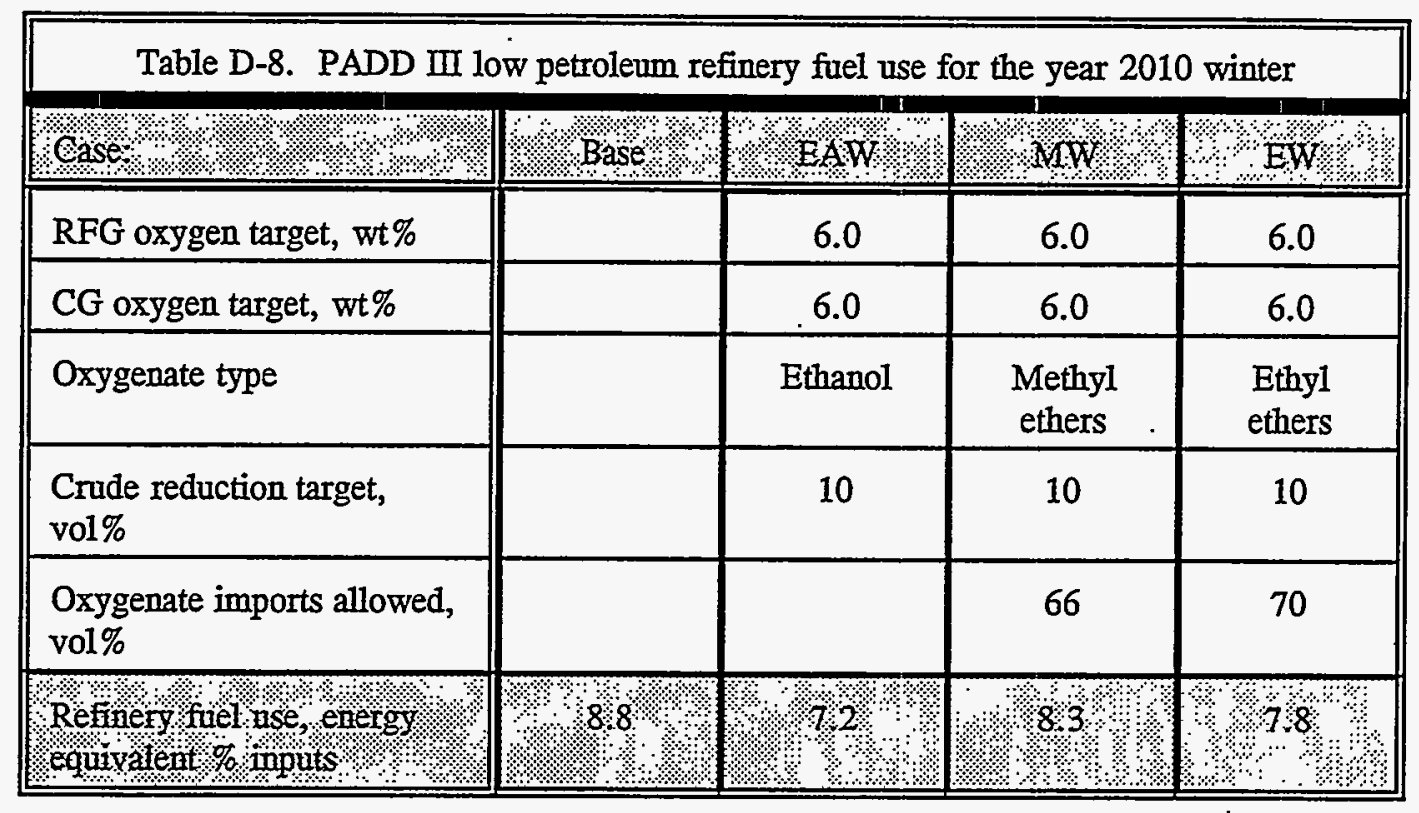

D-8 


\section{APPENDIX E}

LOW PETROLEUM COST CHANGE FOR CG RVP INCREASE TO 8.7 PSI 
Table E-1. PADD III low petroleum cost change for CG RVP increase to 8.7 psi: Ethanol blends

\begin{tabular}{|c|c|c|c|c|c|c|}
\hline Case a & $1 \mathrm{EA}$ & $2 E A$ & $3 \mathrm{EA}$ & $4 \mathrm{EA}$ & $5 \mathrm{EA}$ & $6 \mathrm{EA}$ \\
\hline RFG oxygen target, wt\% & 2.1 & 2.1 & 2.7 & 2.7 & 2.7 & 2.7 \\
\hline CG oxygen target, wt\% & b & & 3.5 & 3.5 & 3.5 & 3.5 \\
\hline $\begin{array}{l}\text { Crude reduction target, } \\
\text { vol\% }\end{array}$ & & & 10 & 15 & 15 & 10 \\
\hline Forced hydrogenation? & No & No & No & No & No & Yes \\
\hline RFG VOC reduction, $\min \%$ & 30 & 24 & 30 & 30 & 30 & 30 \\
\hline CG RVP, $\max$ psi & 7.9 & 7.9 & 7.9 & 7.9 & 8.7 & 7.9 \\
\hline costs & $\begin{array}{r}\mathrm{C} \\
\mathrm{Costb} \\
\end{array}$ & $\begin{array}{l}\text { above } \\
\text { Wdot } \\
\end{array}$ & $\begin{array}{l}\text { otted lin } \\
\text { assun } \\
\text { line is } \\
\end{array}$ & $\begin{array}{l}\text { ts for co } \\
\text { jtion } \\
\text { telastic } \\
\text { in }\end{array}$ & $\begin{array}{l}\text { Ent } \\
\text { ice as } \\
\text { ice } \\
\end{array}$ & mption \\
\hline \multirow{2}{*}{$\begin{array}{l}\text { Refining cost increase, cents } \\
\text { per physical gallon of } \\
\text { gasoline }\end{array}$} & -0.54 & -0.87 & -3.71 & $-4.76^{b}$ & 0 & -4.53 \\
\hline & -0.63 & -0.88 & -5.09 & $-4.23^{b}$ & 0 & -6.18 \\
\hline \multirow{2}{*}{$\begin{array}{l}\text { Cost of crude reduction, } \$ \\
\text { per barrel }\end{array}$} & $N A^{2}$ & $N^{2}$ & -8.80 & $-7.53^{b}$ & 0 & -10.73 \\
\hline & $\mathrm{NA}^{2}$ & $\mathrm{NA}^{2}$ & -12.05 & $-6.69^{b}$ & 0 & -14.65 \\
\hline \multicolumn{7}{|c|}{$\begin{array}{l}{ }^{2} \text { Cases are not crude reduction strategies } \\
\text { bFrom sensitivity case } 5 \mathrm{E} \text { (all other estimates based on marginal cost of RVP } \\
\text { reduction) }\end{array}$} \\
\hline
\end{tabular}


Table E-2. PADD III low petroleum cost change for CG RVP increase to 8.7 psi: Methyl ether oxygenates

\begin{tabular}{|c|c|c|c|c|c|c|c|}
\hline $\mathrm{case}_{\mathrm{as}} / 2 \%$ & 114 & $2 \mathrm{M}$ & $3 \mathrm{M}$ & $4 \mathrm{M}$ & $5 \mathrm{M}$ & $6 \mathrm{M}$ & $7 \mathrm{M}$ \\
\hline RFG oxygen target, wt\% & 2.1 & 2.7 & 2.7 & 2.7 & 2.7 & 6.0 & 6.0 \\
\hline CG oxygen target, wt\% & & 3.5 & 3.5 & 3.5 & 3.5 & 6.0 & 6.0 \\
\hline Crude reduction target, vol\% & & 10 & 10 & 15 & 10 & 10 & 10 \\
\hline $\begin{array}{l}\text { Oxygenate imports allowed, } \\
\text { vol\% }\end{array}$ & 43 & 43 & 0 & 43 & 43 & 43 & 71 \\
\hline Forced hydrogenation? & No & No & No & No & Yes & No & No \\
\hline costs? & ?. & $\begin{array}{l}\text { iabove } \\
\text { st boeroy }\end{array}$ & $\begin{array}{l}\text { otted lin } \\
\text { fotoded }\end{array}$ & is for & $\begin{array}{l}\text { astant p } \\
\text { asticp pro } \\
4\end{array}$ & $\begin{array}{l}\text { assiunp } \\
\text { ssump }\end{array}$ & मी: \\
\hline \multirow{2}{*}{$\begin{array}{l}\text { Refining cost increase, cents } \\
\text { per physical gallon of gasoline }\end{array}$} & -0.59 & -0.06 & 0 & -0.11 & -0.09 & $\mathbf{0}$ & 0 \\
\hline & -1.01 & -0.08 & 0 & -0.15 & -0.11 & 0 & 0 \\
\hline \multirow{2}{*}{$\begin{array}{l}\text { Cost of crude reduction, } \$ \text { per } \\
\text { barrel }\end{array}$} & $N A^{2}$ & -0.13 & 0 & -0.17 & -0.20 & 0 & 0 \\
\hline & $N^{2}$ & -0.18 & 0 & -0.24 & -0.25 & 0 & 0 \\
\hline
\end{tabular}


Table E-3. PADD III low petroleum cost change for CG RVP increase to 8.7 psi: Ethyl ether oxygenates

\begin{tabular}{|c|c|c|c|c|c|c|c|}
\hline Case & $1 E$ & $2 \mathrm{E}$ & $3 \mathrm{E}$ & 48 & $5 \mathrm{E}$ & $6 \mathrm{E}$ & $7 \mathrm{~T}$ \\
\hline RPG oxygen target, wt\% & 2.1 & 2.7 & 2.7 & 2.7 & 6.0 & 6.0 & 6.0 \\
\hline CG oxygen target, wt\% & & 3.5 & 3.5 & 3.5 & 6.0 & 6.0 & 6.0 \\
\hline Crude reduction target, vol\% & & 10 & 15 & 10 & 10 & 10 & 17 \\
\hline $\begin{array}{l}\text { Oxygenate imports allowed, } \\
\text { vol\% }\end{array}$ & 43 & 43 & 43 & 43 & 43 & 43 & 43 \\
\hline Forced hydrogenation? & No & No & No & Yes & No & No & No \\
\hline Linear acetaledhyde emissions? & No & No & No & No & No & Yes & No \\
\hline Costs & $\begin{array}{l}\ddots \% \\
\vdots \\
\vdots \\
\vdots\end{array}$ & astol & dotted & is for & stant & assuim & H \\
\hline \multirow{2}{*}{$\begin{array}{l}\text { Refining cost increase, cents } \\
\text { per physical gallon of gasoline }\end{array}$} & -0.39 & -0.16 & -0.09 & -0.13 & 0 & 0 & 0 \\
\hline & -0.49 & -0.20 & -0.12 & -0.15 & 0 & 0 & 0 \\
\hline \multirow{2}{*}{$\begin{array}{l}\text { Cost of crude reduction, } \$ \text { per } \\
\text { barrel }\end{array}$} & $N A^{2}$ & -0.38 & -0.14 & -0.31 & 0 & 0 & 0 \\
\hline & $N^{2}$ & -0.47 & -0.18 & -0.36 & 0 & 0 & 0 \\
\hline
\end{tabular}




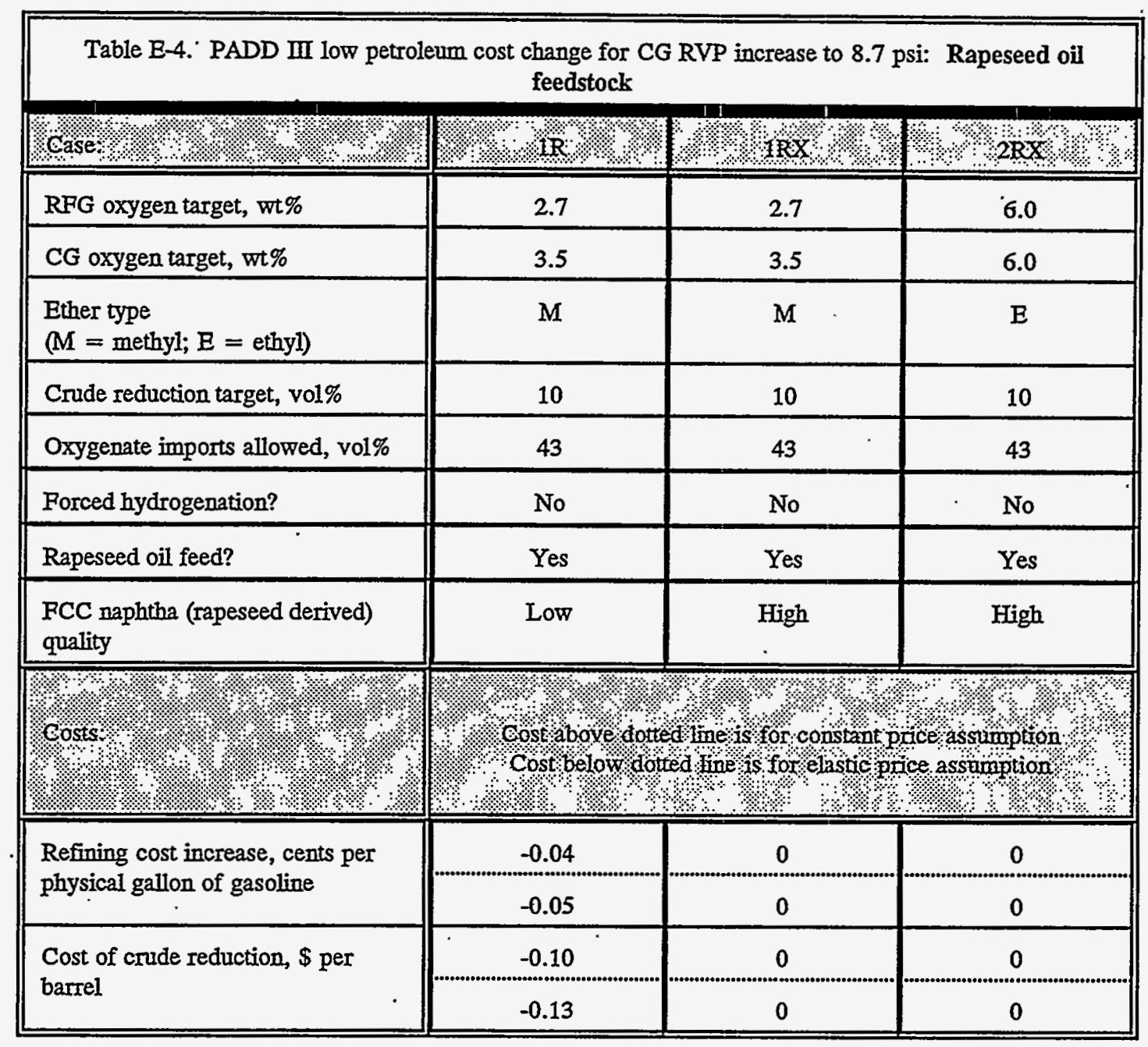




\section{INTERNAL DISTRIBUTION}

1. M. S. Bronzini

2. G. E. Courville

3-5. D. L. Greene

6. G. R. Hadder

7. P.S. Hu

8. D. P. Middendorf

9. R. D. Perlack
10. R. B. Shelton

11. ORNL Patent Office

12. Central Research Library

13. Document Reference Section

14. Laboratory Records

15. Laboratory Records--RC

\section{EXTERNAL DISTRIBUTION}

16-19. B. McNutt, Office of Energy Demand Policy, U. S. Department of Energy, PE-50 Room 7H-021, Forrestal Building, 1000 Independence Avenue, Washington, DC 20585

20-21. M. Clauson, Energy and Environmental Analysis, Inc., 1655 North Fort Meyer Drive, Arlington, VA 22209

22-23. G. M. Webb, Energy and Environmental Analysis, Inc., 1655 North Fort Meyer Drive, Arlington, VA 22209

24. J. Holmes, Energy and Environmental Analysis, Inc., 1655 North Fort Meyer Drive, Arlington, VA 22209

25. A. Roberts, Office of Naval Research, Navy Energy \& Natural Resources Office, Code ONR12E, 800 North Quincy Street, Arlington, VA 22217-5000

26. M. Tallett, EnSys Energy and Systems, Inc., 523 Sergeantsville Road, Flemington, NJ 08822

27. M. Singh, Argonne National Laboratory, 955 L'Enfant Plaza, SW, Suite 6000, Washington, DC 20024

28. T. Nguyen, U. S. Department of Energy, EE-331, Forrestal Building, 1000 Independence Avenue, Washington, DC 20585-0121

29-59. Center for Transportation Analysis, Energy Division, 5500A, MS-6366, Room A204

60. Office of Assistant Manager for Energy, Research and Development, DOE-ORO, P.O. Box 2001, Oak Ridge, Tennessee 37831

61-62. OSTI, U.S. Department of Energy, P.O. Box 62, Oak Ridge, Tennessee 37831 
$\mid$ 